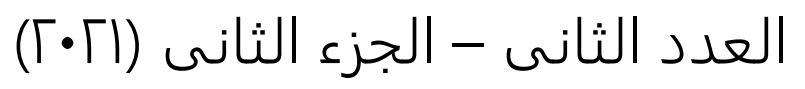

\title{
برنامج تدريبي قائم علي استراتيجيات ما وراء المعرفة لاي تلاميذ المرحلة الابتدائية ذوي صعوبات التعلم لتحسين بعض عادات مات العقل
}

\author{
عمرو علي تحمد يونس
}

\author{
إثراف
}

د/ شادية عبدالعزيز مهتدي ***

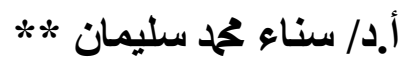

هدفت البحثل إلي الكثف عن مدى فاعلية برنامج تدريبي قائم علي استر اتيجيات مـاور اء المعرفة لتحسين

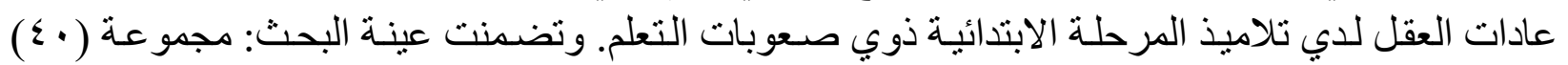

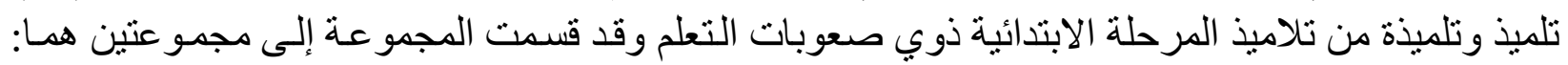

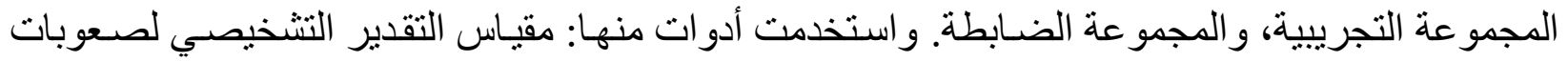

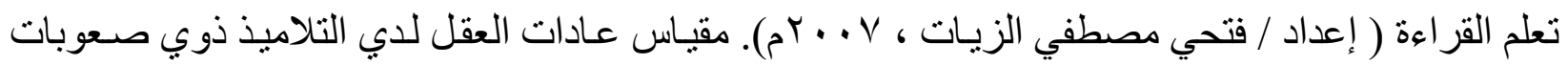

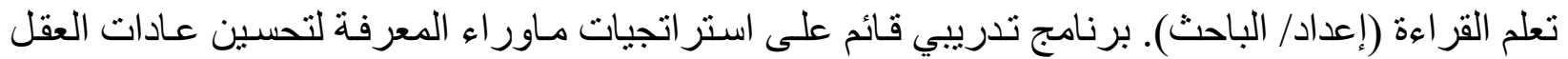

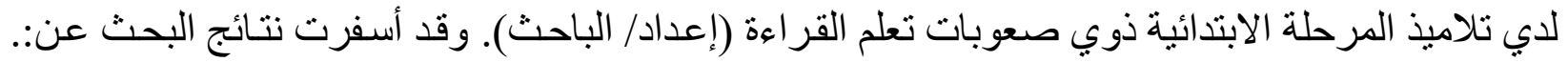

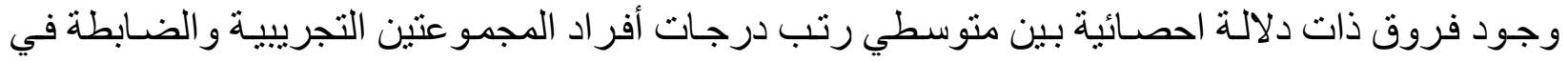

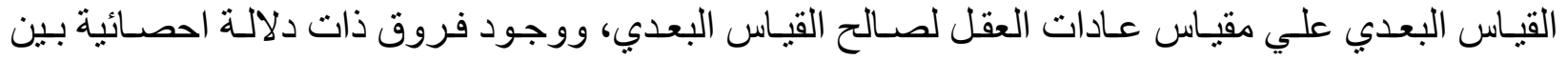

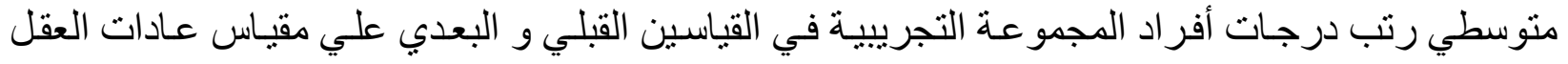

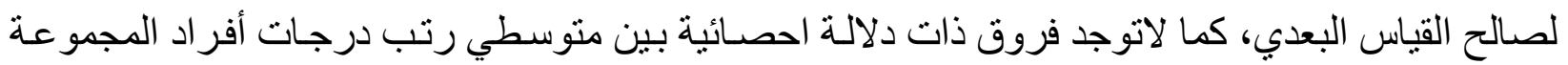

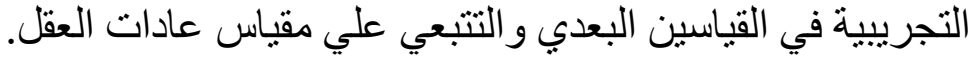

الكلمات المفتاحية: ما ور اء المعرفة ـ عادات العقل - صعوبات التعلم

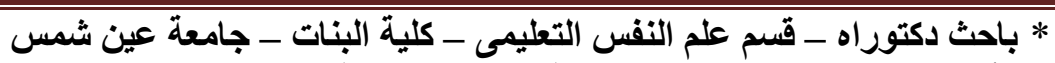

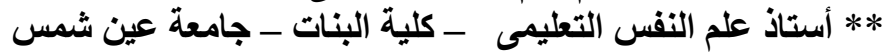

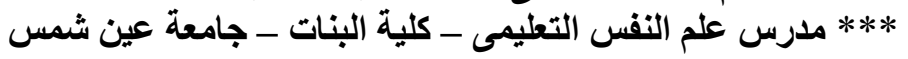




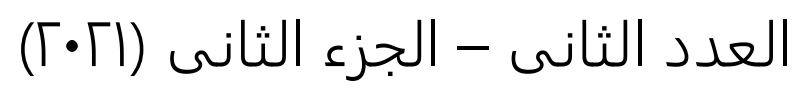
مجلة بحوث

"العلوم التربوية"

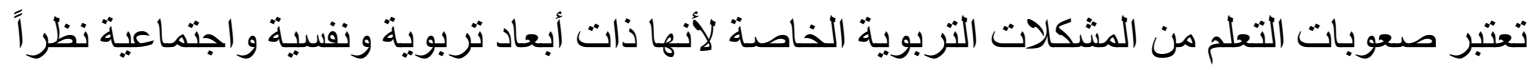

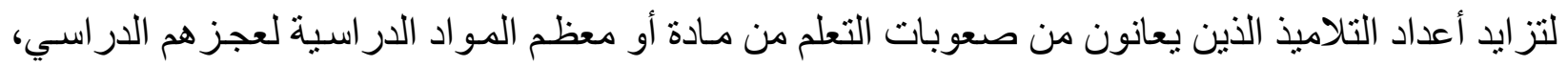

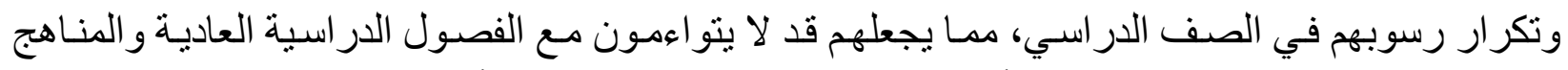

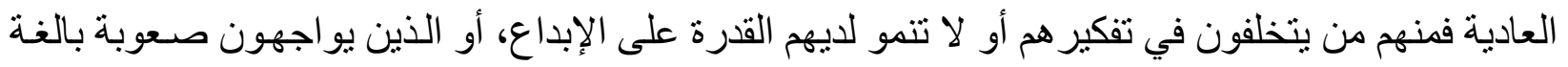

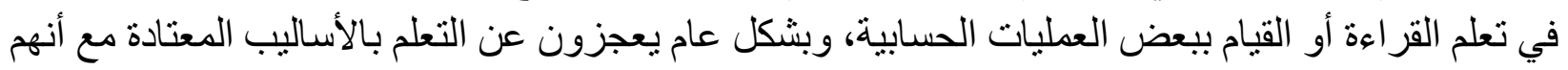

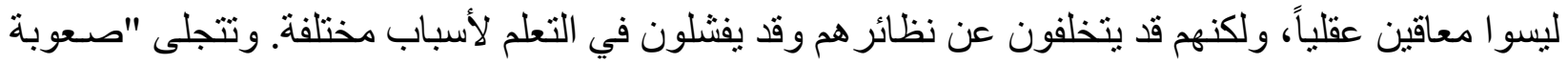

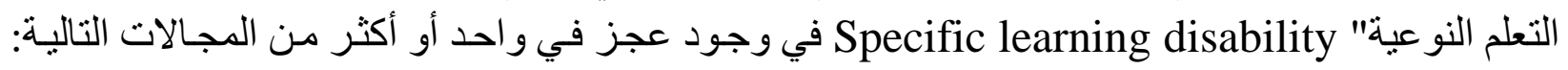

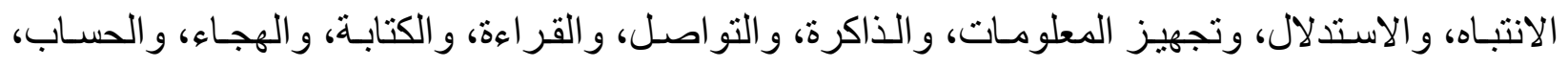

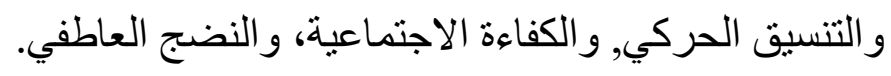

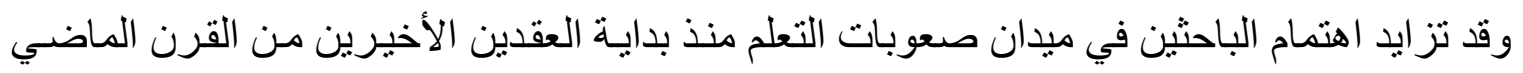

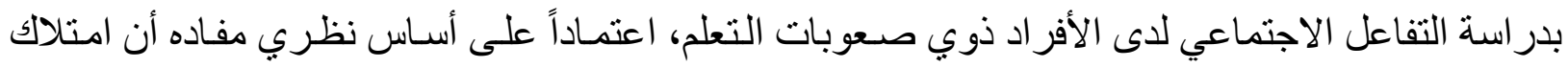

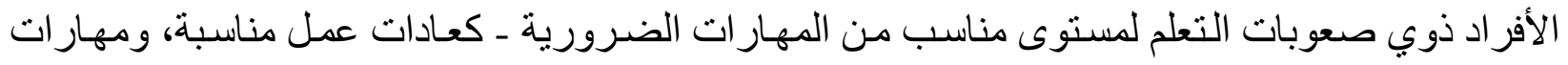

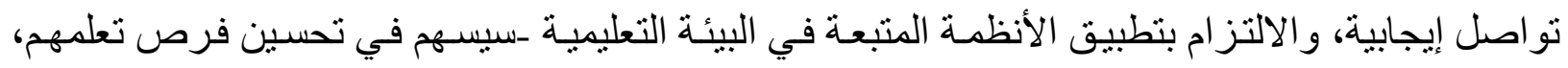

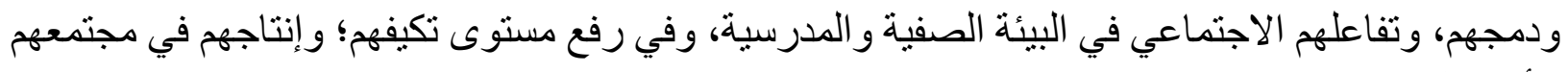
الأكبر الذي يعيشون به (Kavale, 2019, 207-221) .

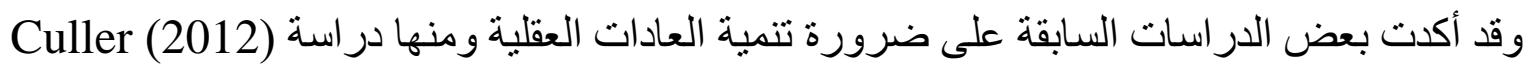

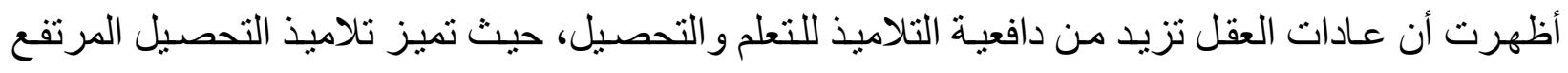

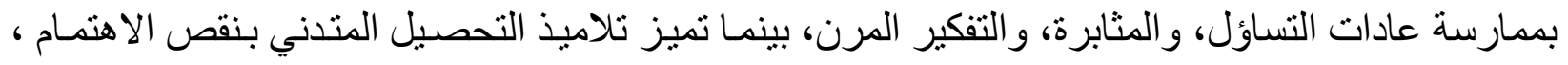

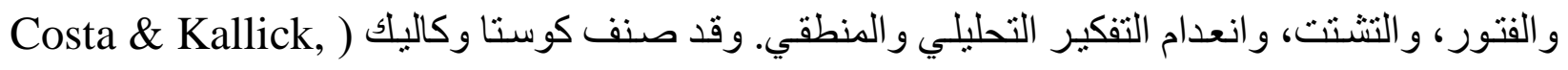

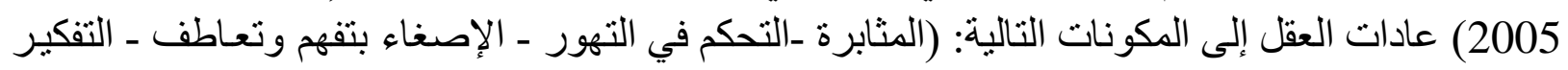

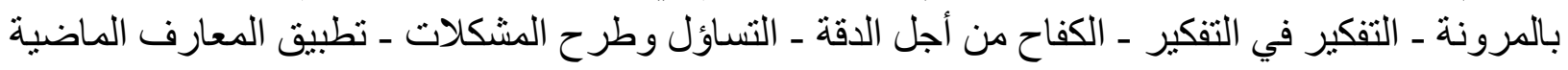

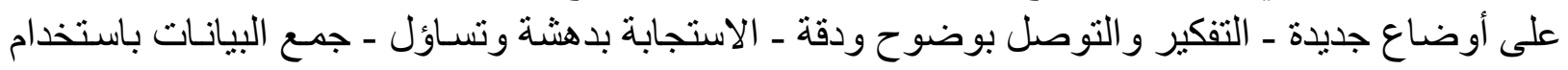

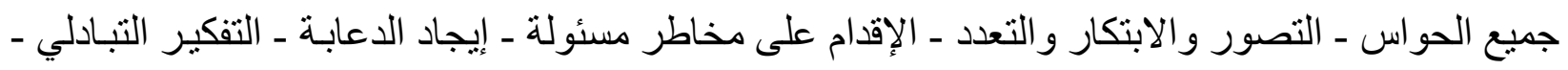
الاستعداد الدائم للتعلم المستمر ).

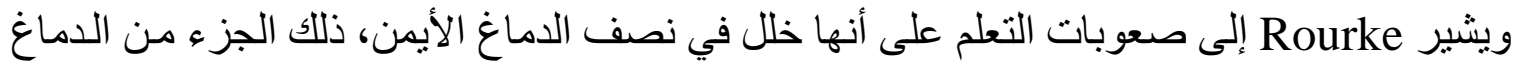

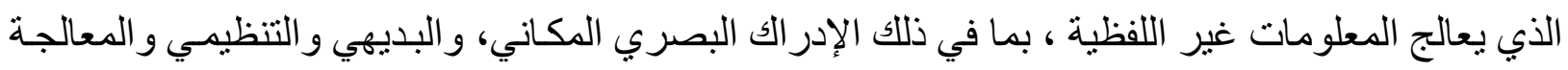
التقييمية (Rourke, 2020, 45).

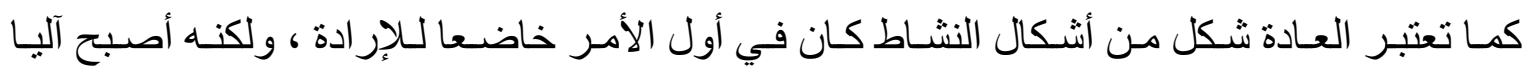

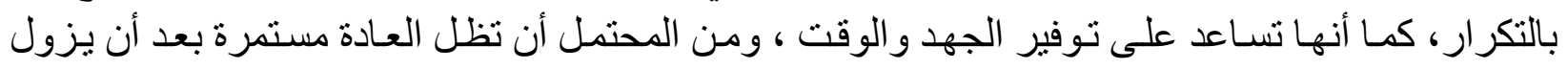

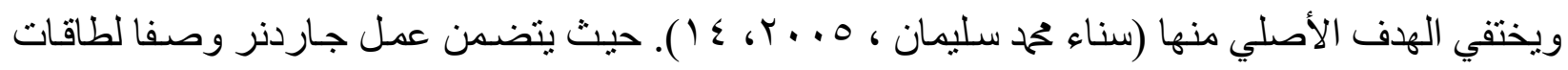

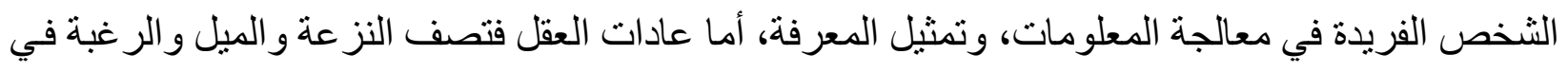




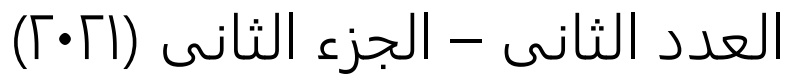 مجلة بحوث \\ "العلوم التربوية"}

استخدام ميول معينة، وفي نفس الوقت الانشغال بعملية معالجة المعلومات ؛ فالتناميذ الذين يتفوقون في جانب

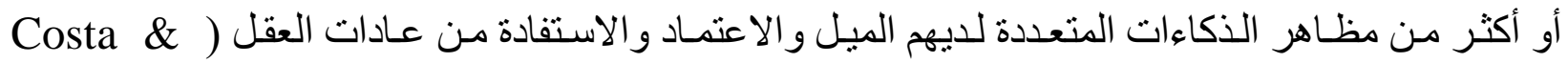
(Kallick, 2005, 235 . لذلك فالمجال التربوي في حاجه إلى المزيد من الدر اسات التي تعمل على تحسين عادات العقل و هذا ما يعني به البحث الحالي من خلال بحث فاعلية برنامج تدريبي قائم علي استر اتيجيات مـا ور اء المعرفة لتحسين عادات العقل لدي التلاميذ ذوي صعوبات التعلم بالمرحلة الابتدائية.

مشكله البحث وأسئلته

برزت مشكلة البحث من خلال ملاحظة أن التلاميذ ذوي صعوبات تعلم القر اعة يعانون من ضعف في

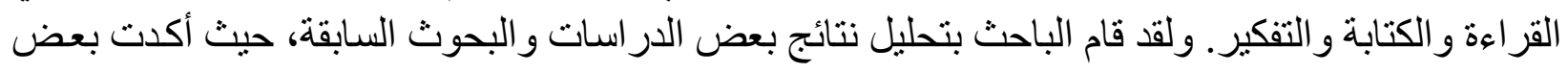
الدر اسات ضعف تلاميذ المرحلة الابتدائية ذوي صـعوبات تعلم القر اعة في التفكير ومنها در اسـة أحمد عبد

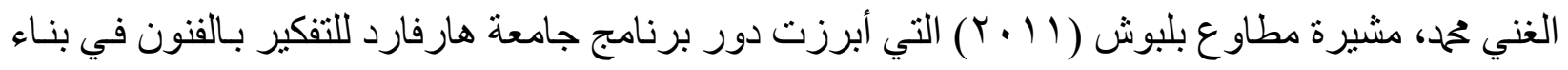

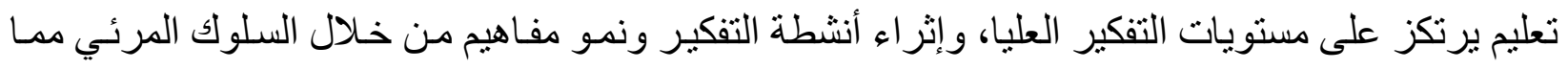

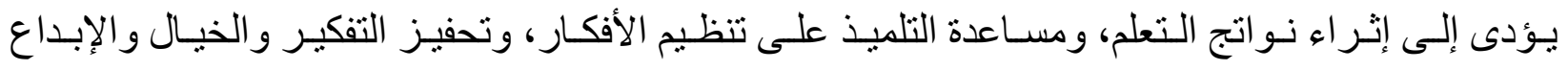

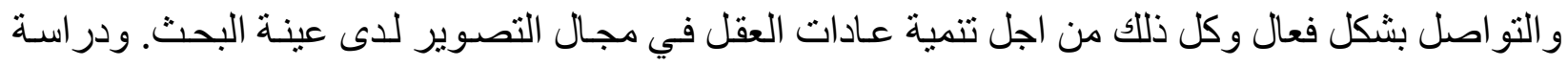
Culler (Y. I Y) التحصيل المرتفع بممارسة عادات التساؤل، و المثابرة، والتفكير المرن، بينمـا تميز تلاميذ التحصيل المتدني بنقص الاهتمام ، و الفتور ، و التشتت، و انعدام التفكير التحليلي و المنطقي. ويمكن صياغة أسئلة البحث على النحو التالي:

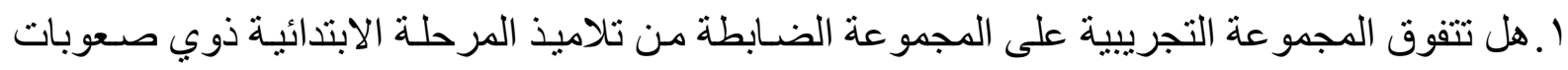

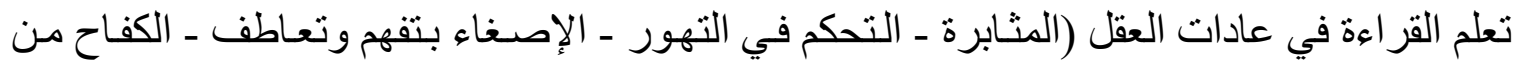

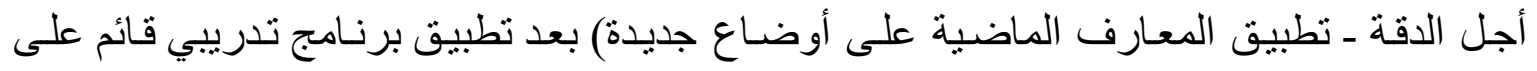

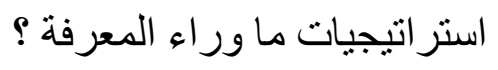

ץ. هل تتحسن عادات العقل (المثابرة ـ التحكم في التهور ـ الإصغاء بتفهم وتعاطف ـ الكفاح من أجل الدقة

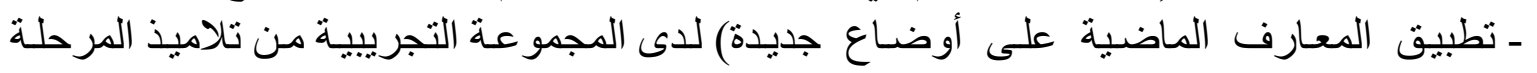
الابتدائية ذوي صعوبات تعلم القر اعة من قبل إلى بعد تطبيق برنامج تدريبي قائم على استر اتيجيات ما

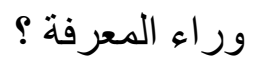

ץ. هل تختلف عادات العقل (المثابرة ـ التحكم في التهور ـ الإصغاء بتفهم وتعاطف ـ الكفاح من أجل الدقة

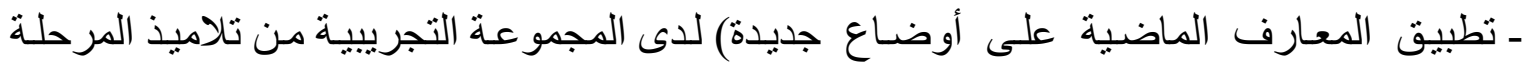

الابتدائية ذوي صعوبات تعلم القر اعة في القياسيين البعدي و التتبعي؟

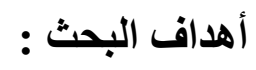

يرهف البحث الحالي إلي ما يأتي:- 


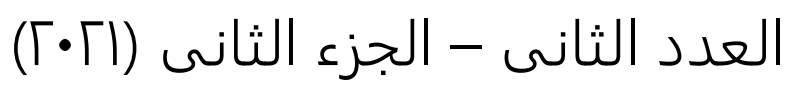
مجلة بحوث

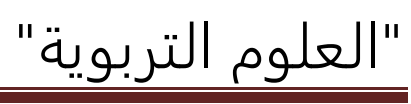

1. الكثف عن الفروق في عادات العقل(المثابرة ـ التحكم في التهور ـ الإصغاء بتفهم وتعاطف ـ الكفاح

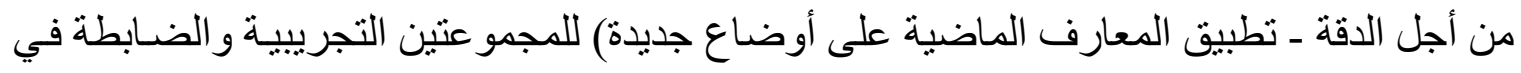

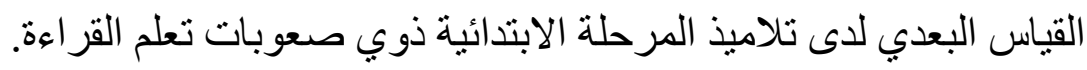

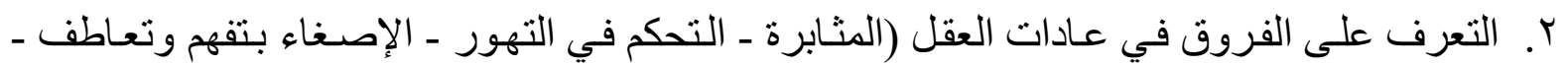

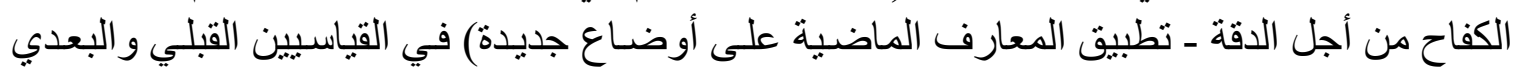

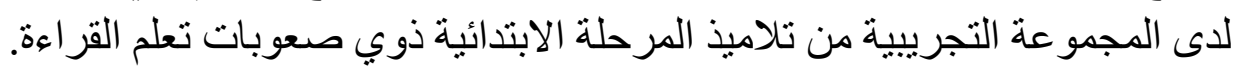
r. الكثف عن الفروق في عادات العقل(المثابرة ـ التحكم في التهور ـ الإصغاء بتفهم وتعاطف ـ الكفاح

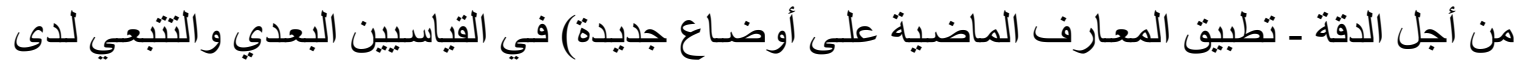

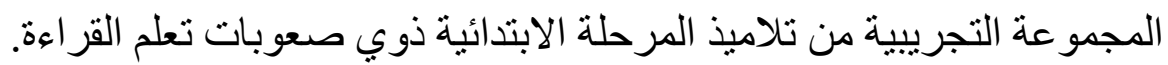

أهمية البحث : أنمر

تمثل أهمية البحث الر اهن في جانبين نظري وتطبيقي وذللك على النحو التالي:-

الأهمية النظرية:

1. أهمية المرحلة العمرية التي يتعرض لها البحث، وهي التلاميذ في المرحلة الابتدائية حيث هم من أهم دعامات أي مجتمع من المجتمعات.

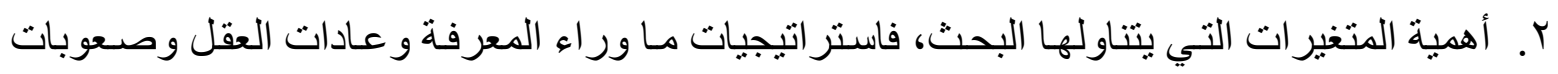

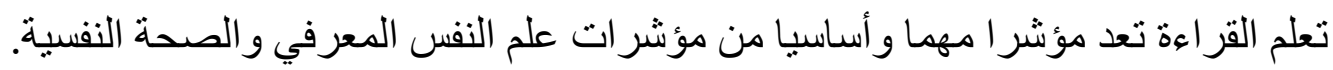

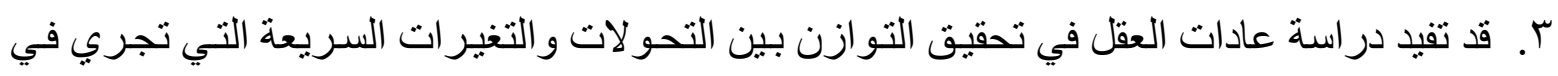

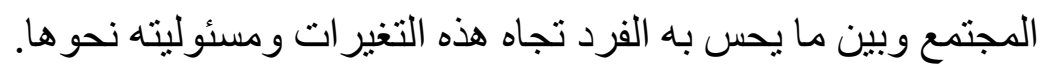

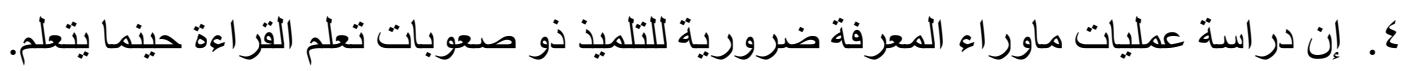

\section{الأهمية التطبيقية:}

ا. . علي المستوي التطبيقي فتبدو أهمية هذا البحث في التوصل إلى نتائج قد تفيد القائمين على التعليم لهذه

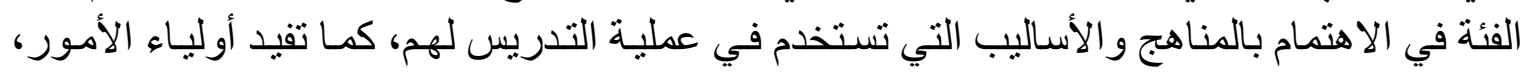
ومؤسسات المجتمع المدني، ومر اكز الأبحاث وطلاب العاب العلم.

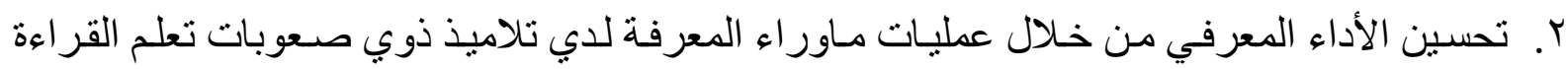

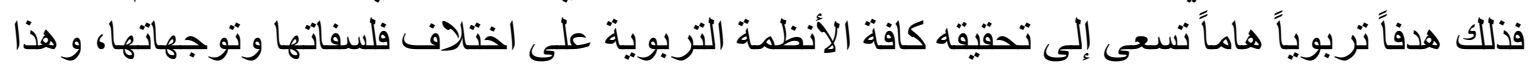

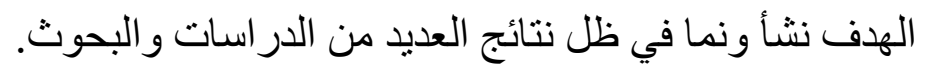

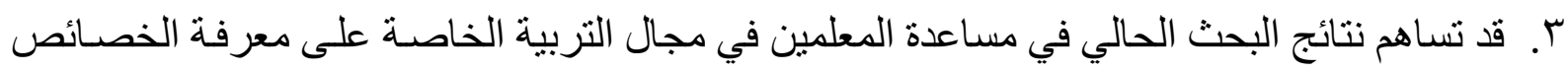

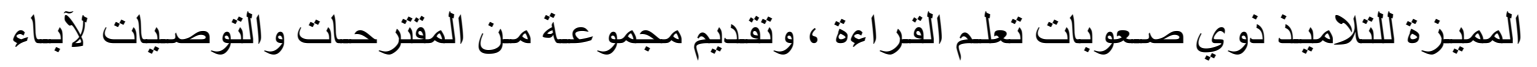




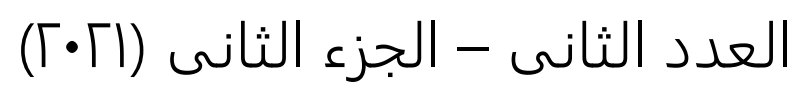

مجلة بحوث

"العلوم التربوية"

ومعلمي هؤلاء التلاميذ لمساعدتهم في اكتشاف الصعوبات المعرفية والسلوكية والانفعالية، الأمر الذي وأي

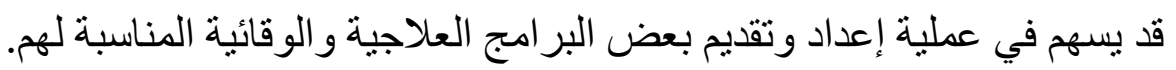

المصطحات الإجرائية للبحث : المبه

ماوراء المعرفة Metacognition

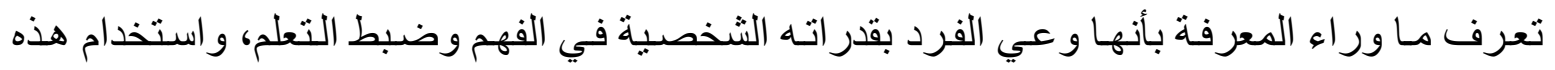

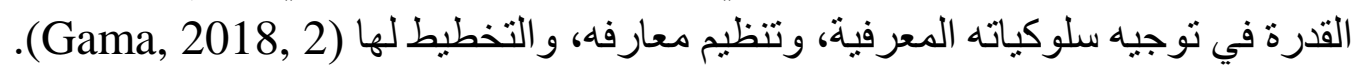

استراتيجيات ماوراء المعرفة فئة

يعرف الباحث استر اتيجيات ما ور اء المعرفة إجر ائيا على أنها مجمو عـة من أنماط و أسـاليب لعمليات

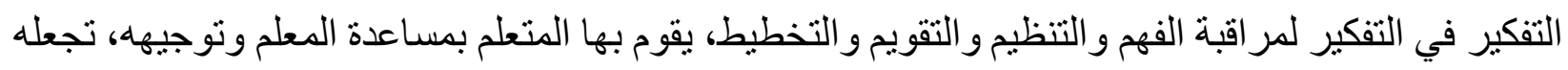

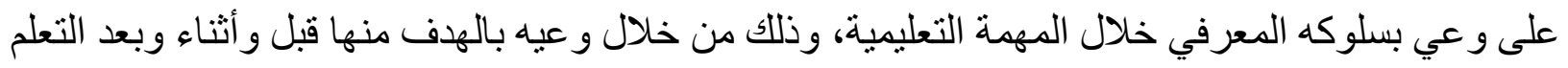

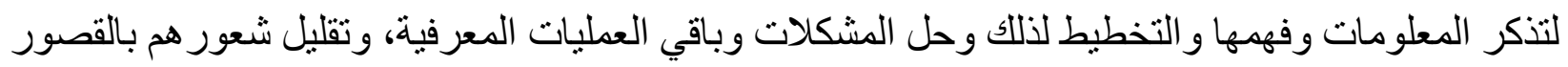

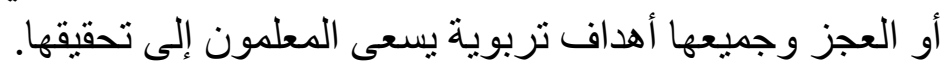

\section{عادات العقل Habits of Mind}

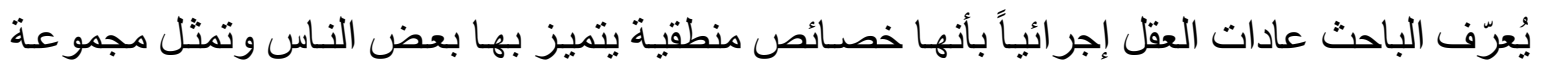

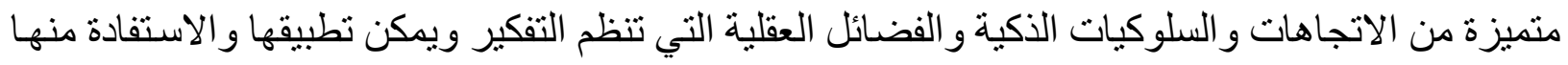

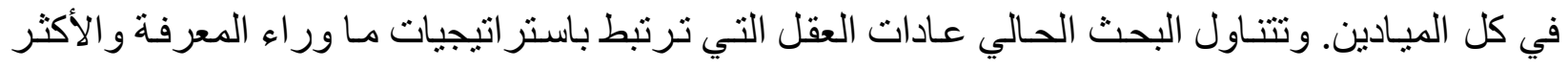

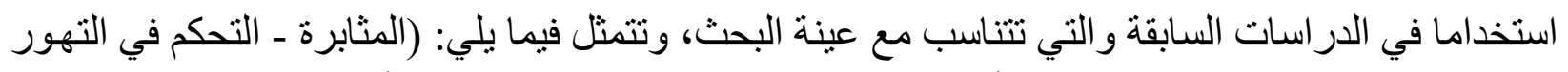

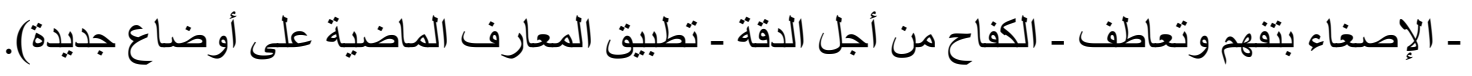

Learning Disabilities صعوبات التعلم

تعرف صعوبات التعلم إجر ائياً علي أنها " ذللك التباعد السلبي الذي يظهره التباتلاميذ بين أدائهم الفعلي

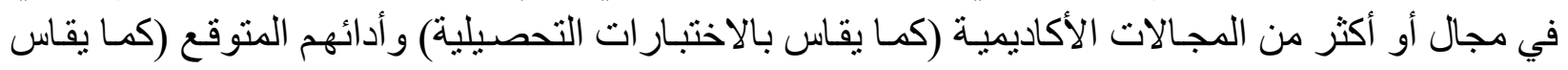

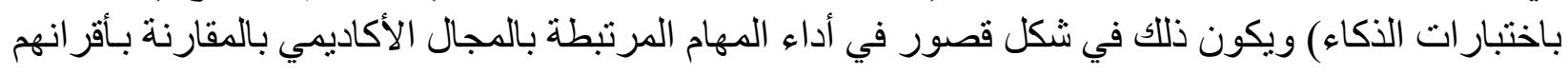

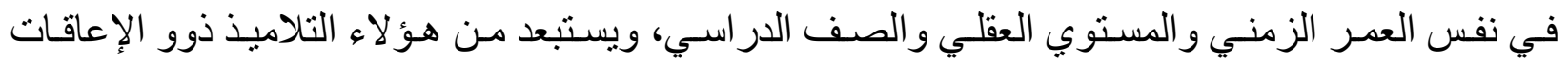

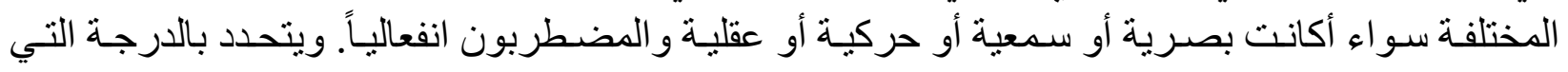
يحصل عليها التلميذ علي الاختبار ات التشخيصية لصعوبة الصبات التعلم. صعوبات تعلم القراعة علمباء

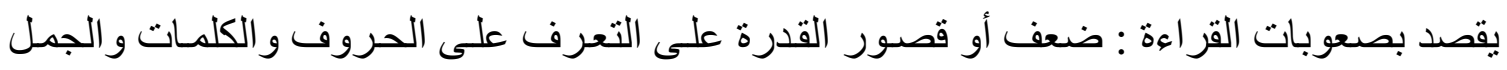

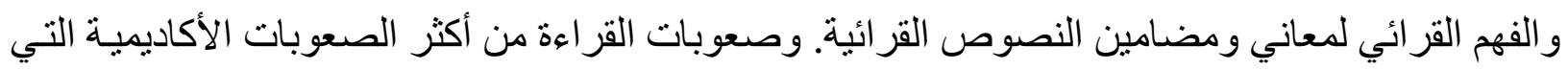

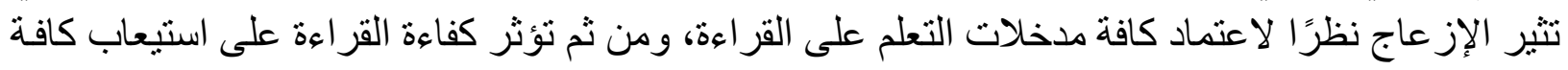

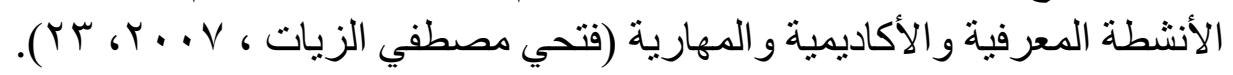




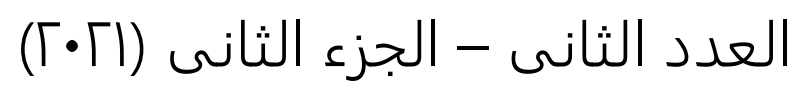

مجلة بحوث

"العلوم التربوية"

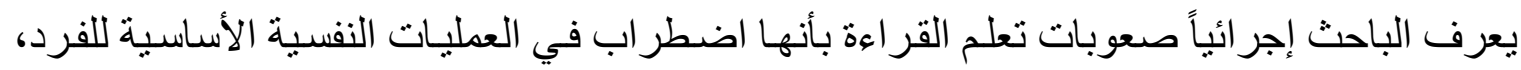

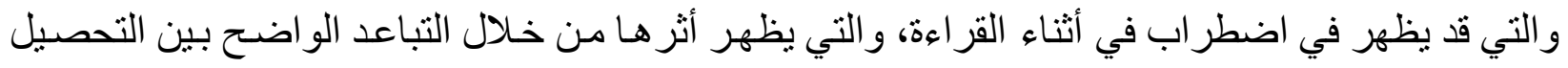

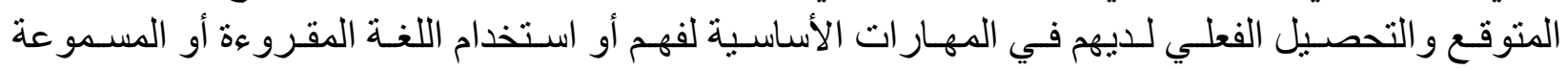
و المجالات الأكاديمية الأخرى، ويكون نتيجة لخلل وظيفي في الدماغ أو مشكلات سلوكية.

دراسات سـابقة : ـ المحور الأول : دراسات تناولت التدريب على استراتيجيات ما وراء المعرفة لاى التلاميذ ذوي صعوبات

التعلم.

دراسة (2009) مenton et al هدفت إلى الكثف عن دور ما ور اء المعرفة و السلوك الإستر اتيجي في

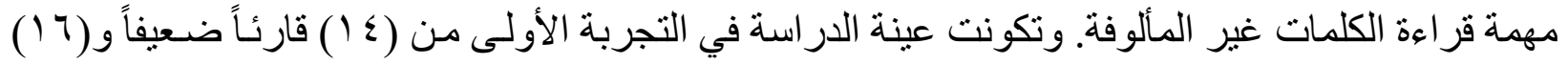

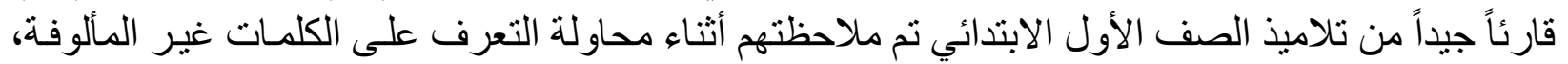

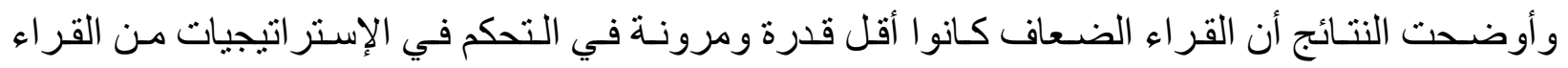

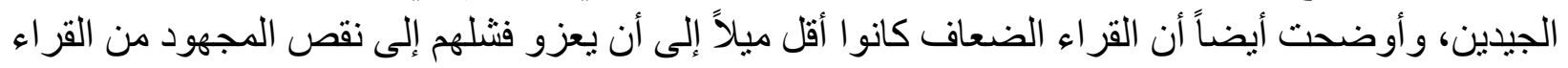

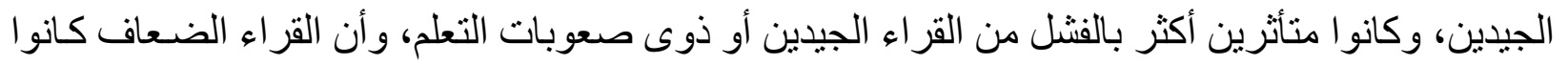

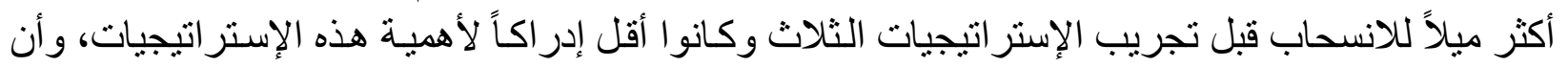

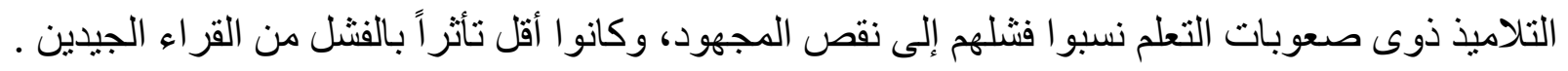

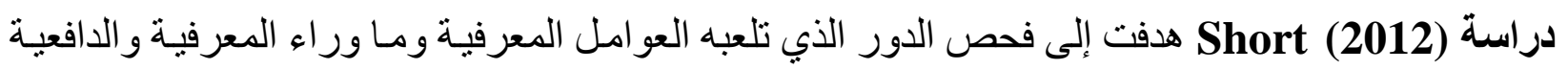

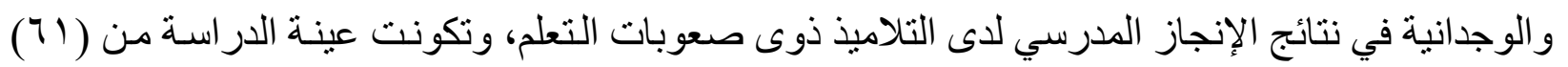

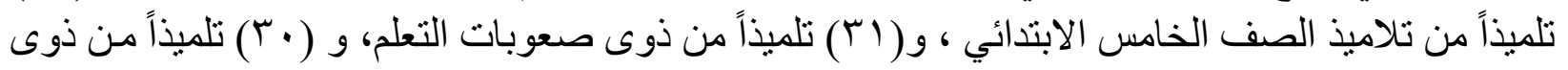

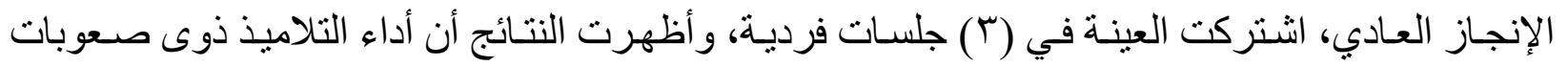

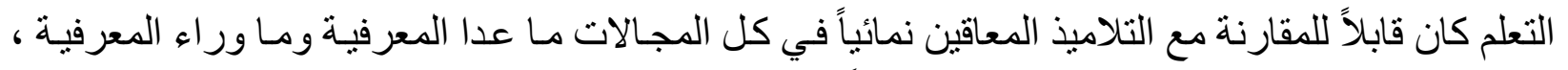

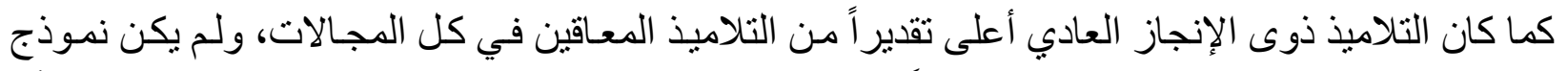

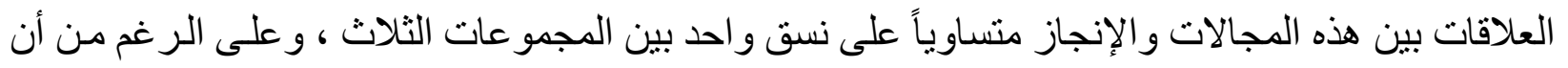

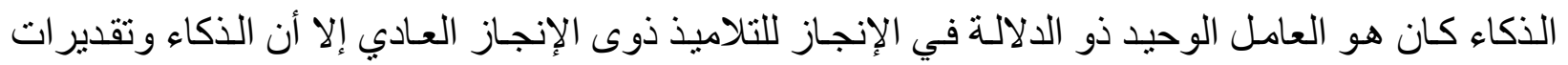

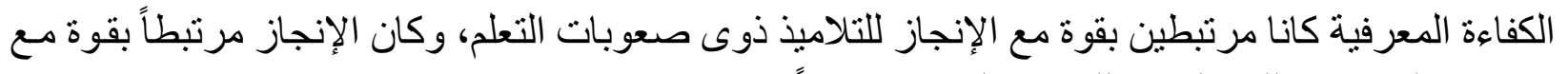
ما وراء المعرفة واللغة الكيفية للتلاميذ المعاقين نمائياً .

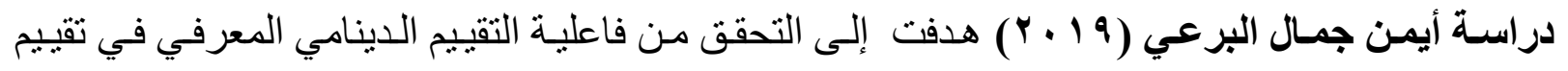

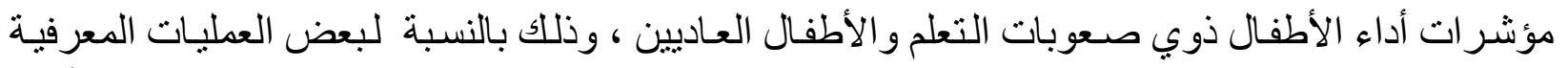

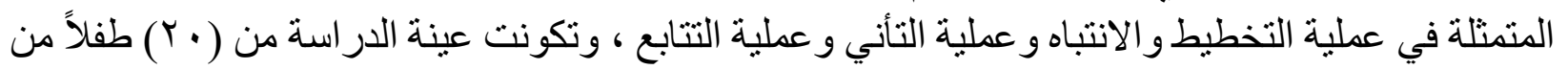

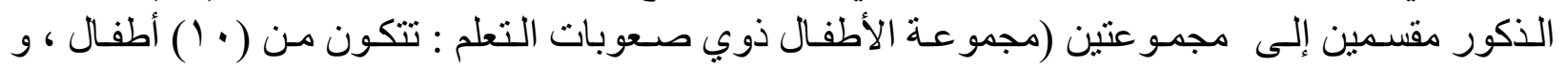

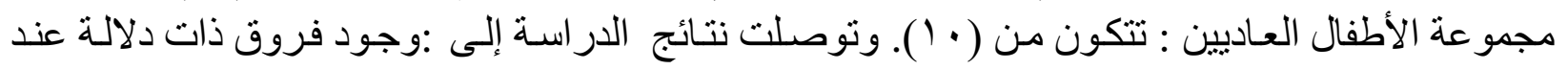




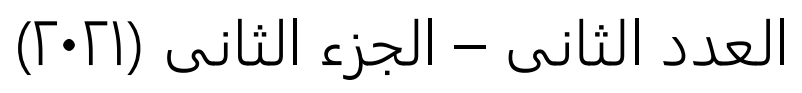
مجلة بحوث

"العلوم التربوية"

مستوى ( 1 • • ) إحصائية بين منوسط رتب درجات الأطفال ذوي صعوبات التعلم في الأداء بالتقييم التقليدي

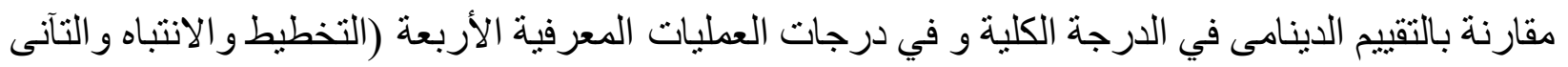

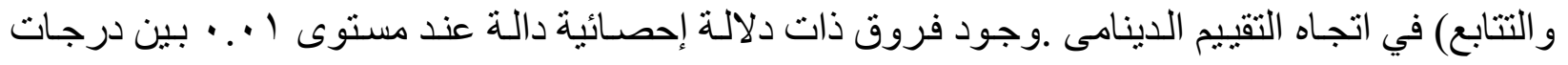

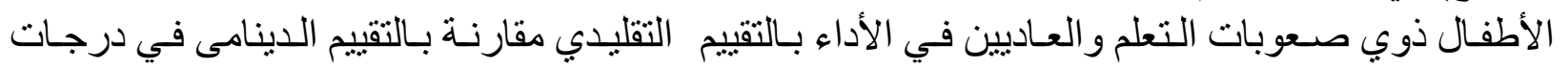

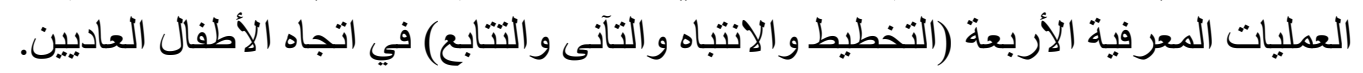

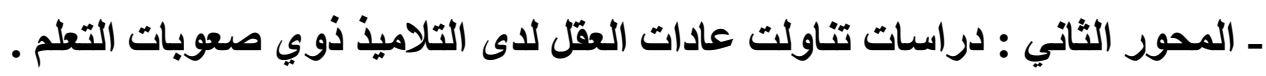

دراسة Culler (2012) هدفت إلى الكثف عن أثر عادات العقل في تحصيل التلاميذ في مادة الرياضيات،

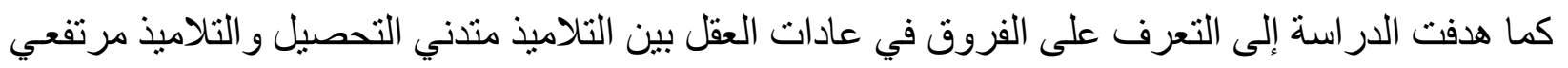

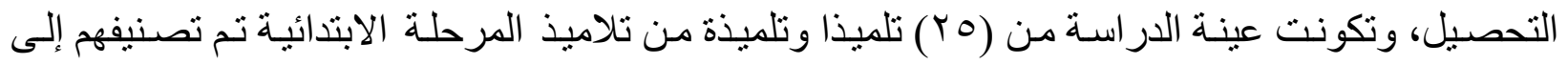

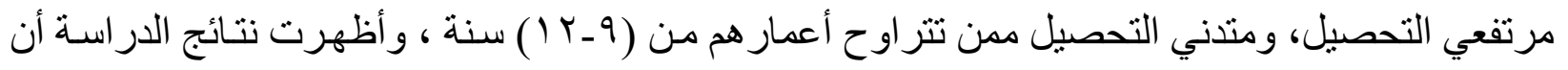

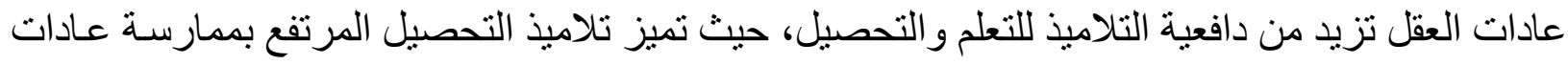

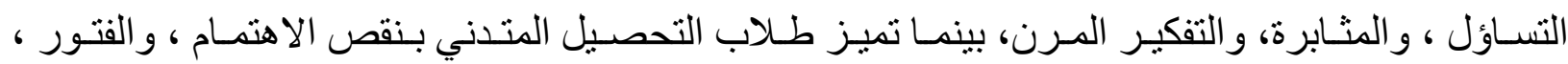
و التشتت، و انعدام التفكير التحليلي و المنطقي.

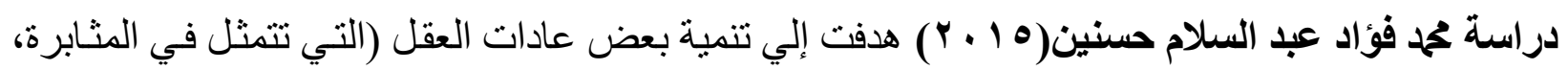

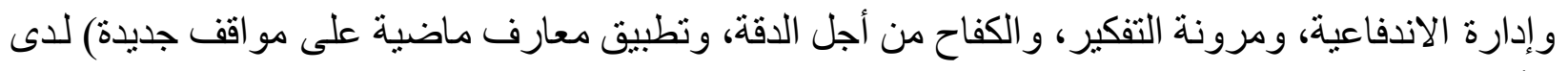

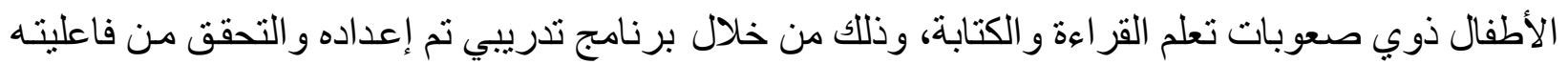

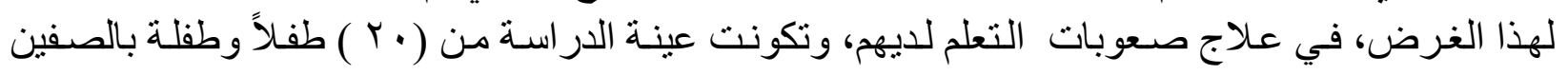

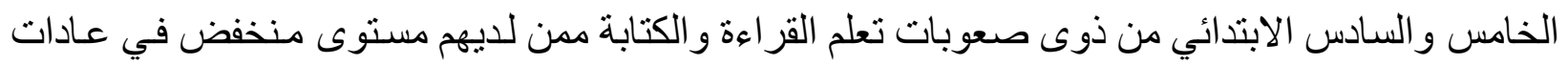

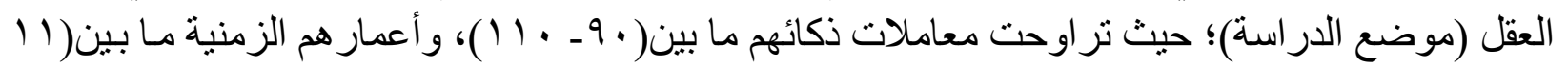

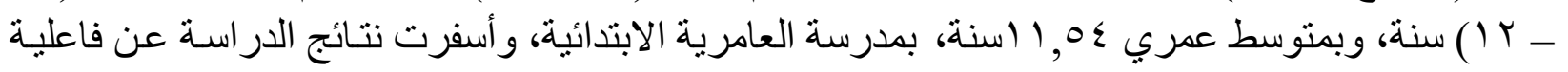
البرنامج في علاج بعض صعوبات التعلم الأكاديمية لاى الأطفال.

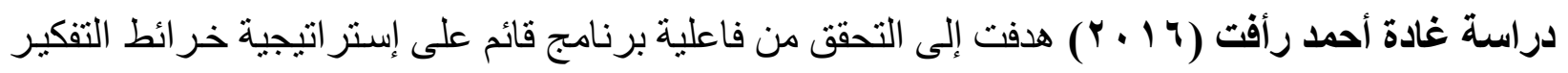

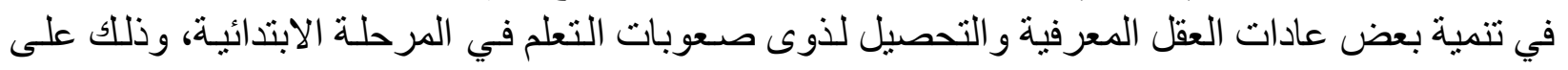

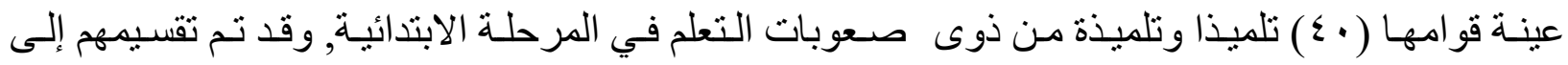

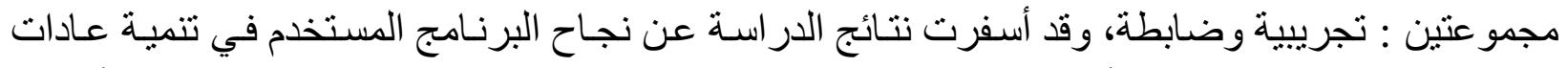

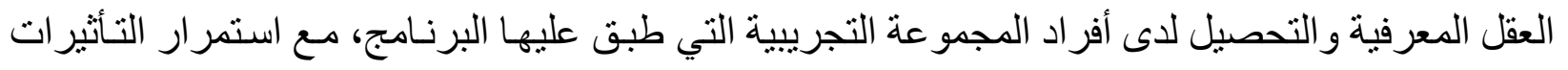
الإيجابية للبرنامج خلال الفترة التتبعية.

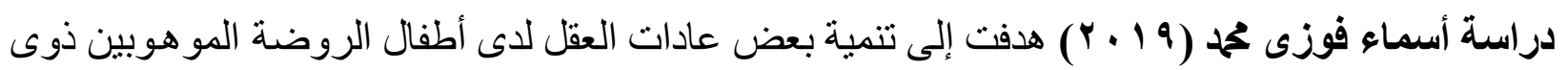

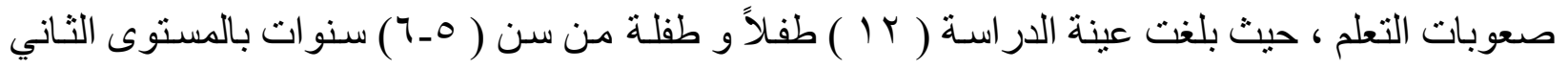

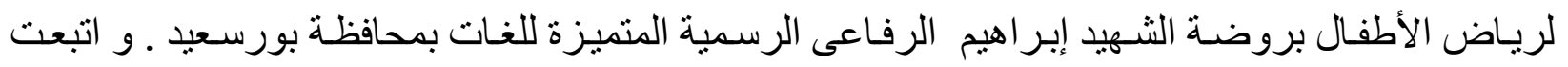




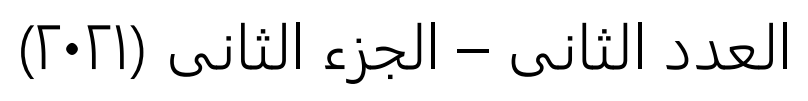

مجلة بحوث

"العلوم التربوية"

الدر اسة الدنهج شبه التجريبي القائم على المجمو عة الواحدة، وتوصلت الدراسة إلى فعالية البرنامج في تنمية

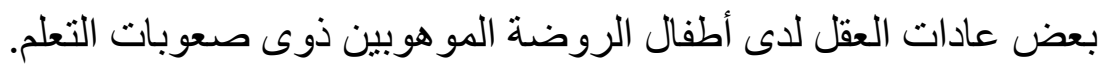

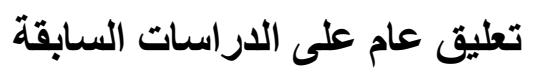

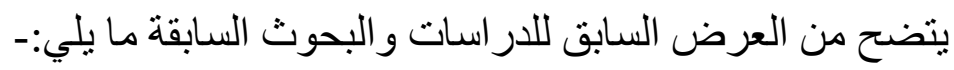

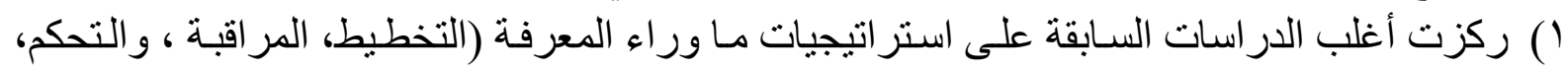

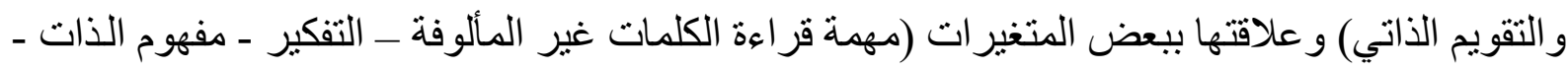

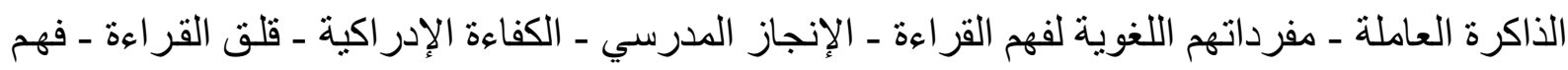

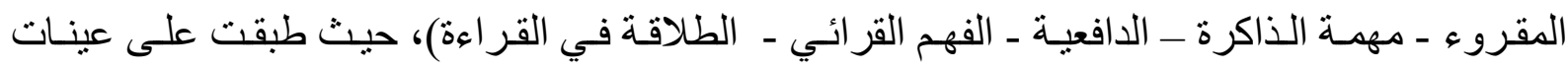

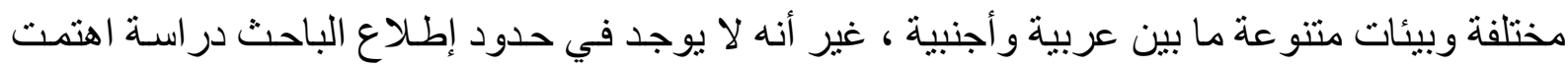

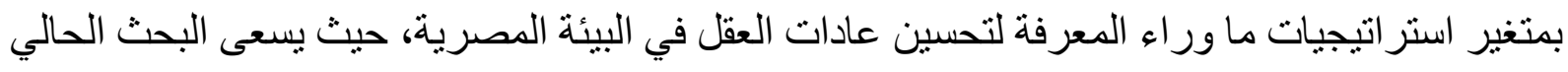

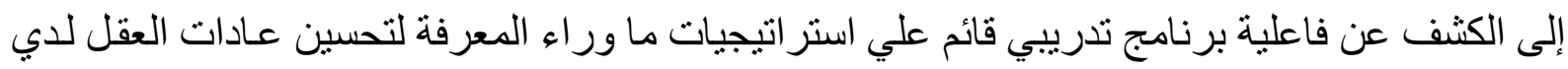

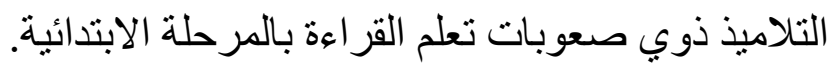

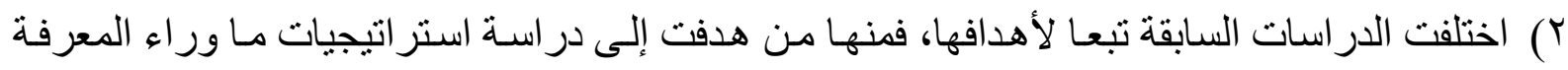

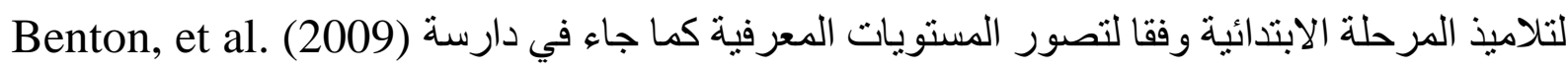

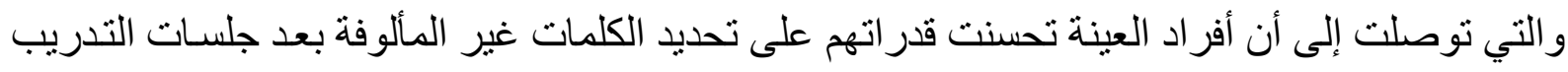

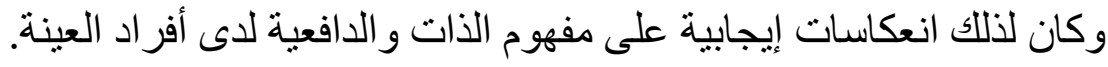

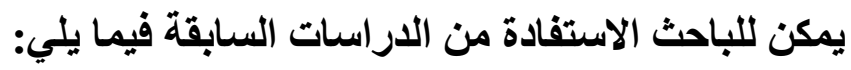

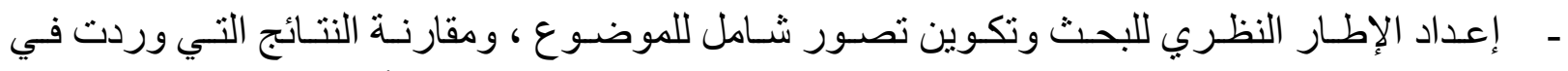

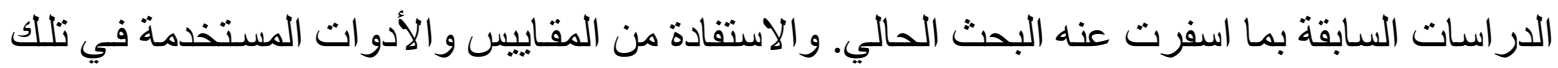

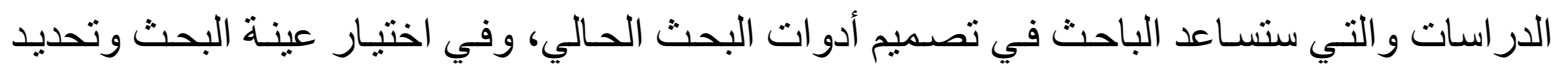
خصائصها بشكل دقيق.

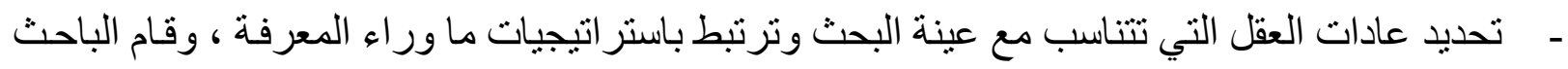

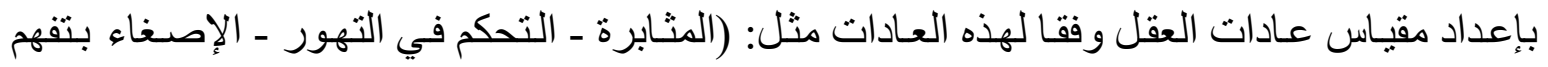

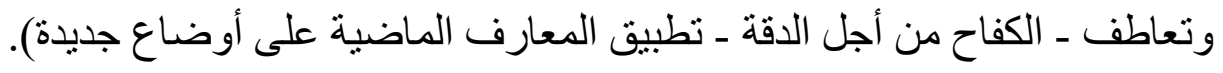

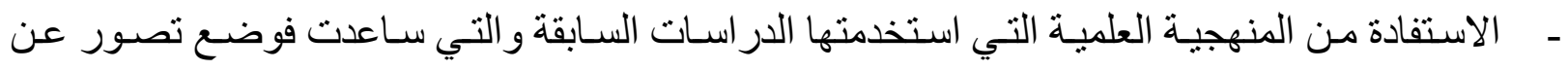

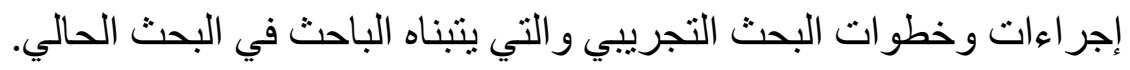

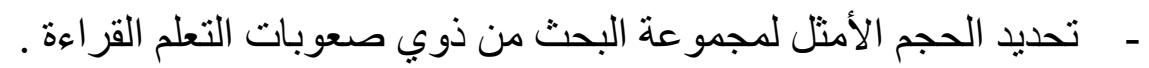
- - تحليل وتفسير ومناقثة نتائج البحث الحمالي.

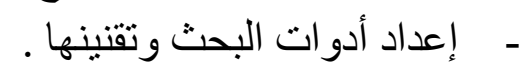

فروض البحث : مما سبق يمكن صياغة الفروض الآتية:-

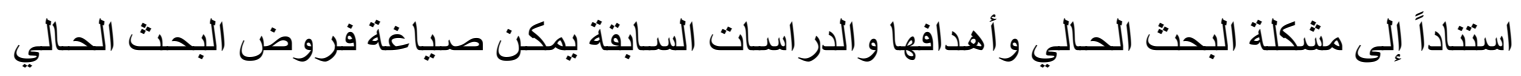
على النحو التالي: 


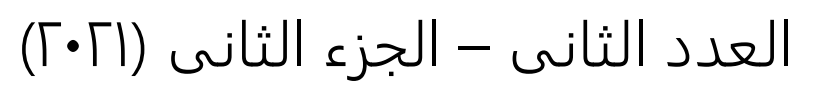

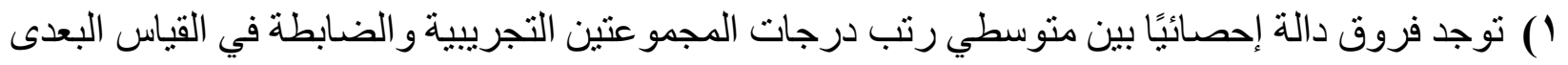

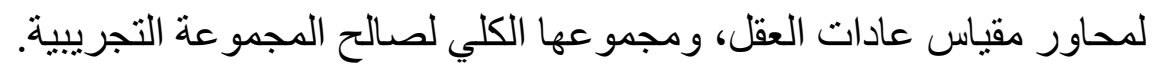

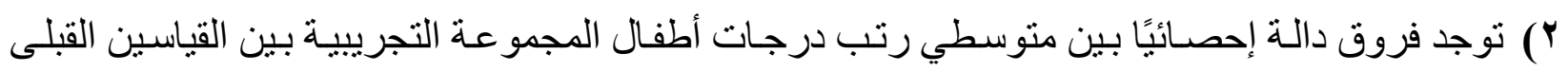

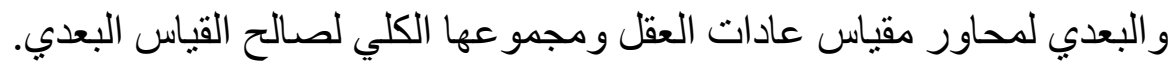

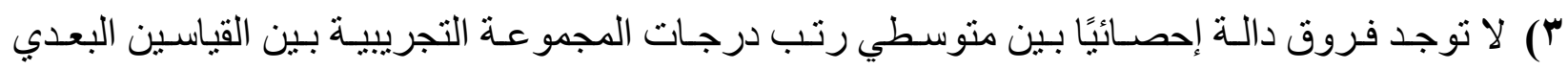

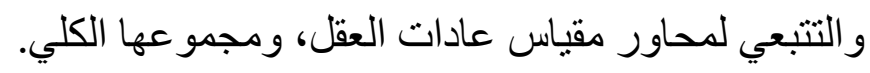

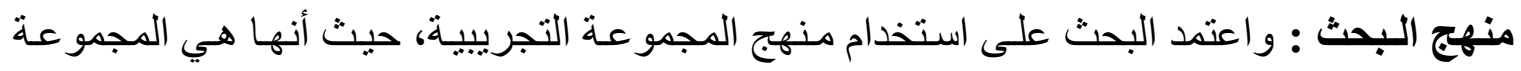

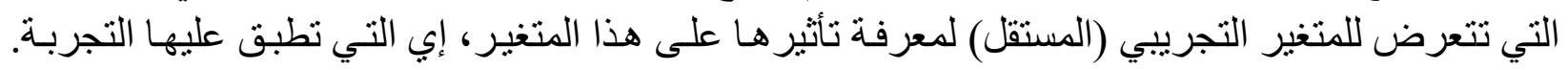

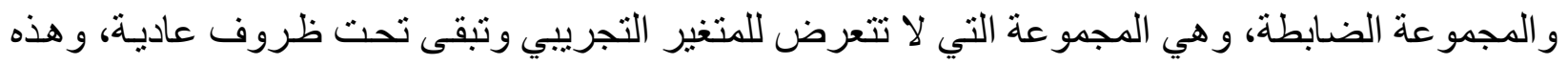

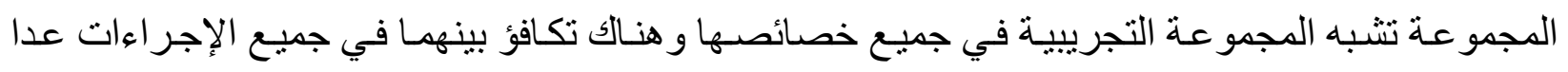
تطبيق التجربة فلا تخضع لها. عينة البحث : تضمنت:

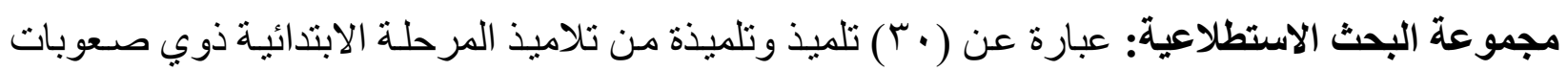

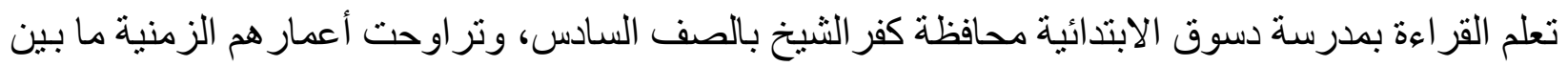

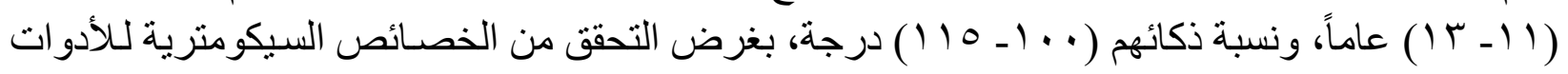

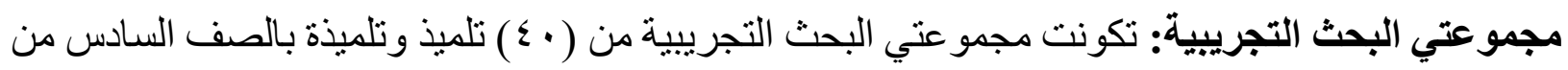

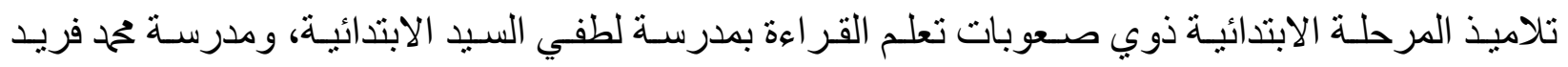

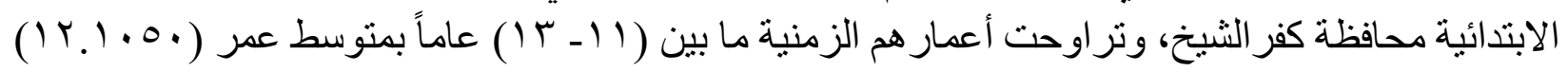

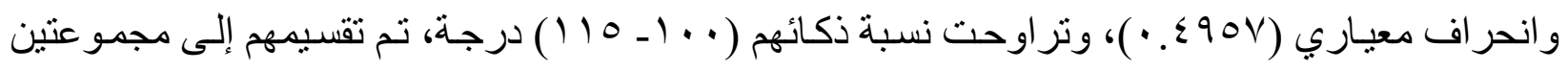
على النحو التالي:-

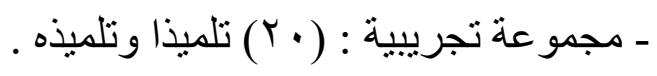
ـ مجمو عة ضابطة : ( • (Y) تلميذا و تلميذه .

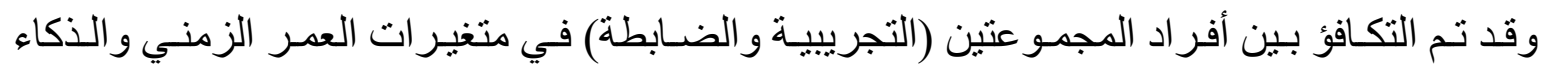

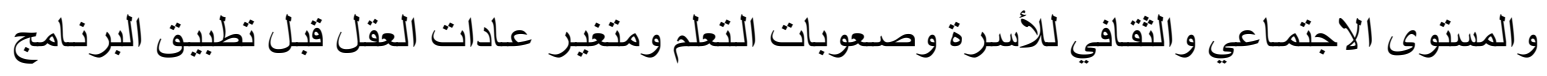

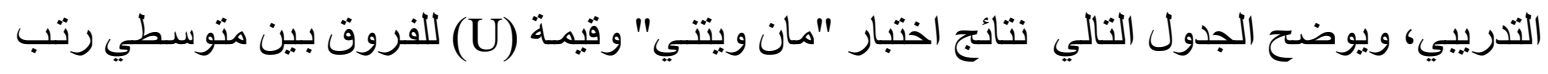

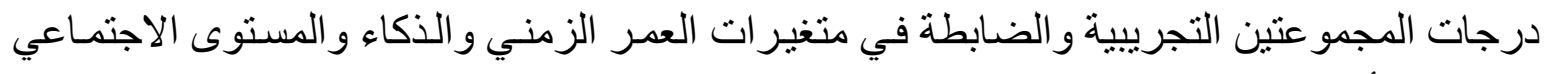
و الثقافي للأسرة وصعوبات التعلم ومتغير عادات العقل. 

العدد الثانى - الجزء الثانى (IГ•「)
مجلة بحوث
"العلوم التربوية"

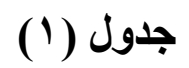

جدول (1) دلالة الفروق بين متوسط درجات المجموعتين (التجريبيةـ الضابطة)

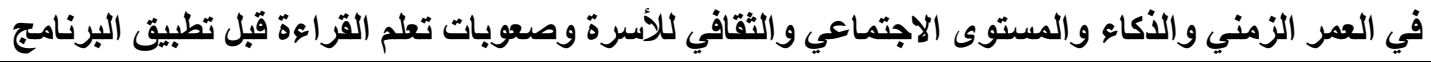

\begin{tabular}{|c|c|c|c|c|c|c|c|}
\hline مستوى الدلالة & قيمة" ت" & درجة الحرية & الانحراف المعياري & المتوسط & ن & المجموعة & المتغير \\
\hline \multirow{2}{*}{ غير دالة } & \multirow{2}{*}{$1.1 . r$} & \multirow{2}{*}{ rs } & $\cdot . \& \wedge \wedge \vee 1$ & $19.19 \ldots$ & $r$. & التجريبية & \multirow{2}{*}{ العمر الزمني } \\
\hline & & & $\cdot \because \& \wedge \vee T$ & $1 Y . \cdot Y \ldots$ & r. & الضابطة & \\
\hline \multirow{2}{*}{ غير دالة } & \multirow{2}{*}{$\therefore \wedge$. } & \multirow{2}{*}{ re } & $r . q V \leqslant 9 r$ & $1.7 . \vee \ldots$ & $r$. & التجريبية & \multirow{2}{*}{ الذكاء } \\
\hline & & & $\varepsilon .9 . \wedge 4 \leqslant$ & $1 . v .9 \ldots$ & r. & الضابطة & \\
\hline \multirow[b]{2}{*}{ غير دالة } & \multirow[b]{2}{*}{.914} & \multirow[b]{2}{*}{$\mu \Lambda$} & $1 . \wedge \leqslant 4 \vee 4$ & $r 4.7 \ldots$ & r. & التجريبية & \multirow{2}{*}{ 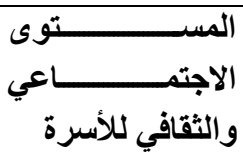 } \\
\hline & & & r..... & $r 4 . \ldots$ & r. & الضابطة & \\
\hline \multirow[b]{2}{*}{ غير دالة } & \multirow[b]{2}{*}{.} & \multirow[b]{2}{*}{ re } & $\varepsilon . r \Delta \leqslant . V$ & or.r... & r. & التجريبية & \multirow{2}{*}{ والقراءة بعوبات تعــــ } \\
\hline & & & ๕.0914T & or.q... & r. & الضابطة & \\
\hline \multirow[b]{2}{*}{ غير دالة } & \multirow[b]{2}{*}{1.1 .9} & \multirow[b]{2}{*}{$\mu \wedge$} & $r . \leqslant 9 \leqslant 4 q$ & $94 . . .$. & $r$ r. & التجريبية & \multirow[b]{2}{*}{ عادات العقل } \\
\hline & & & T.VTIAN & 9 9.।... & r. & الضابطة & \\
\hline
\end{tabular}

قيمة (ت) الجدولية لارجة حرية (r^)

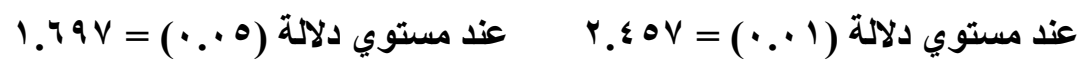

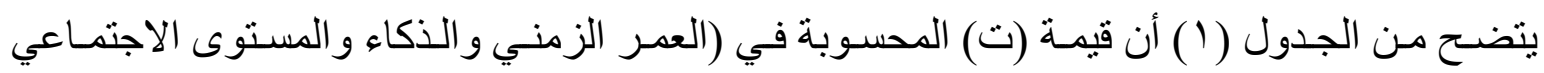

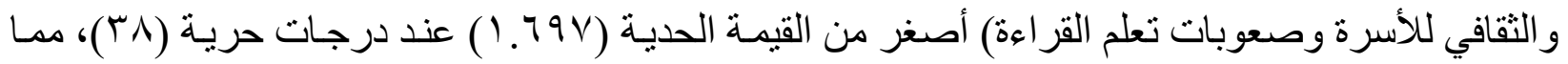

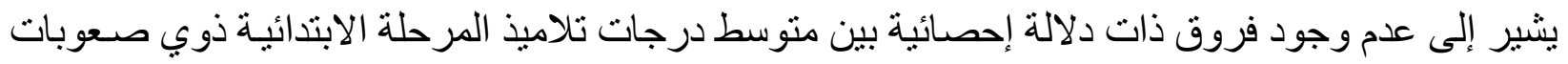

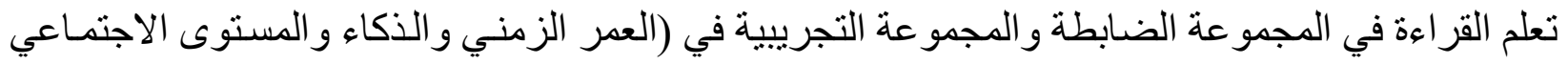

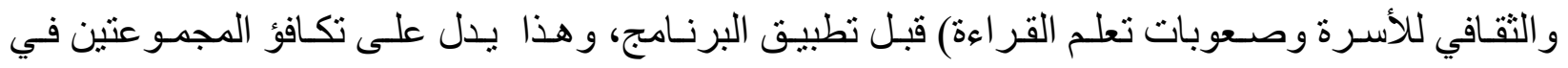
متغير ات الضبط قبل التطبيق.

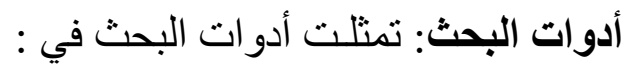
- اختبار المسح النيورولوجي السريع (إعداد/ عبدالوهاب كامل، 9199 (م).

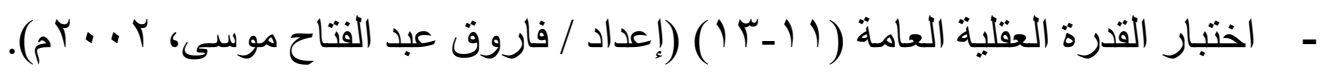

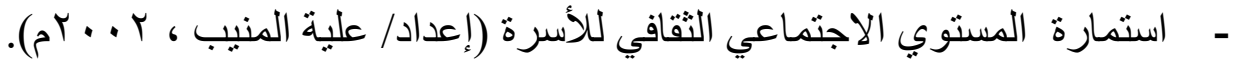

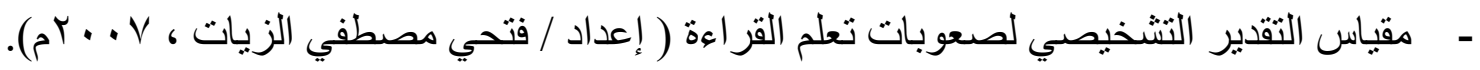
- مقياس عادات العقل لدي تلاميذ المرحلة الابتدائية ذوي صعوبات تعلم القر اءة (إعداد/ الباحثين). 


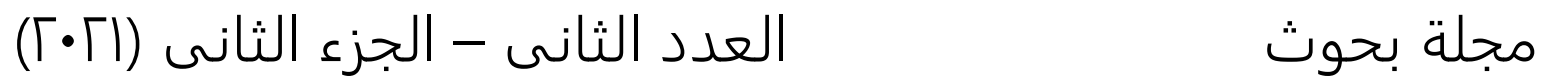 \\ "العلوم التربوية"}

- برنـامج تدريبي قائم على استر اتجيات مـاور اء المعرفة لتحسين عـادات العقل لاي تلاميذ المرحلة الابندائية ذوي صعوبات تعلم القر اءة (إعداد/ الباحثين).

أدوات الدراسة :

الأداة الأولى: اختبار المسح النيورولوجي السريع (*) (إعداد/ عبدالوهاب كامل، 9 ( 9 (م).

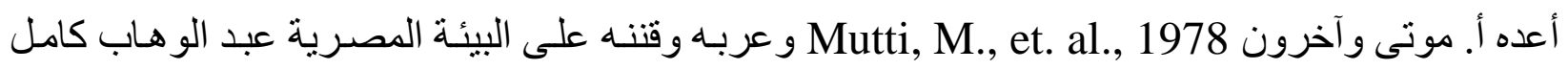

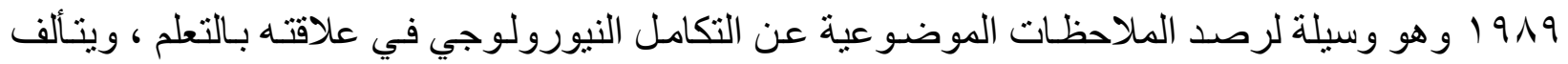

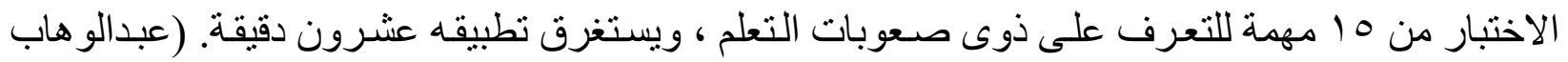

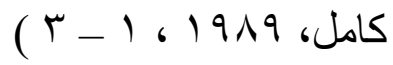

\section{الكفاءة السيكومترية للاختبار}

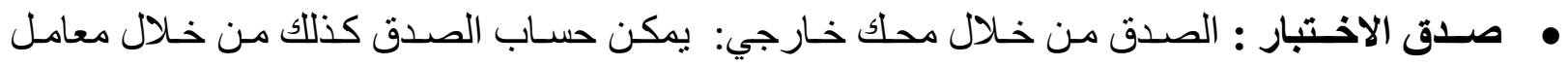

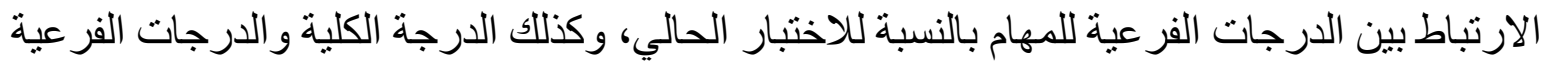
و الكلية لمقياس تقدير سلوك التلميذ لفرز حالات صعو بات لاتلات التعلم.

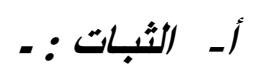

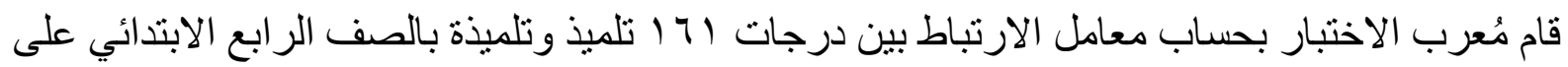

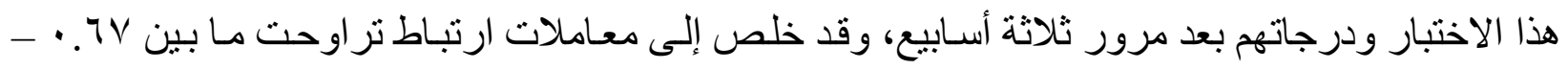

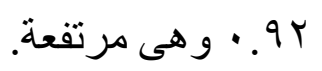

وقد قام الباحث الحالي بحساب ثبات هذا المقياس باستخدام طريقة الإجر اء و إعادة الإجر اء بفاصل زمني

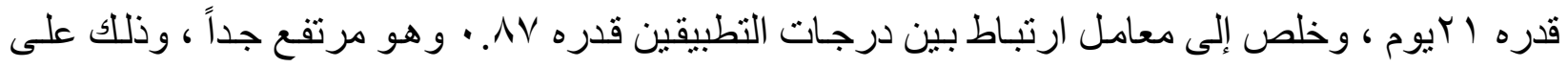

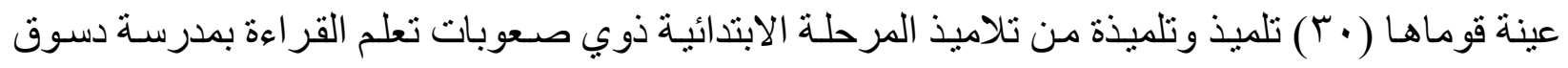

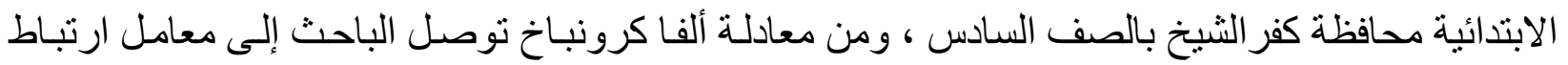

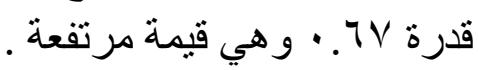

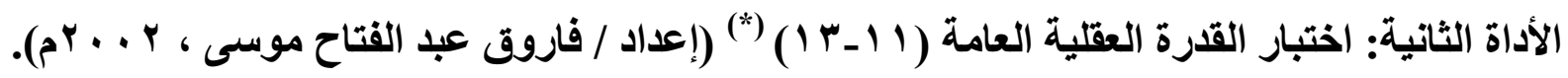

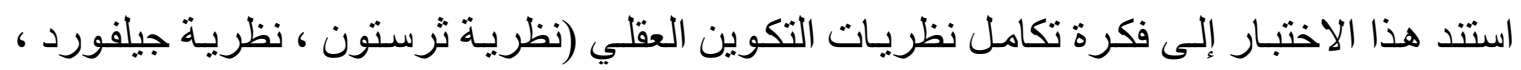

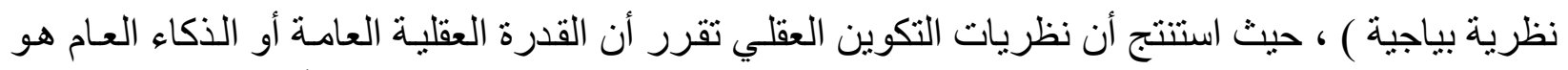

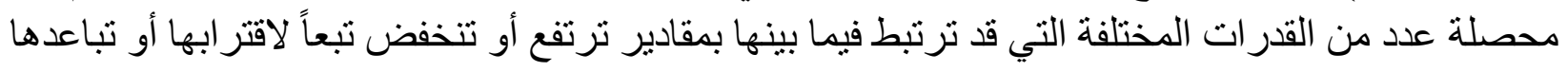

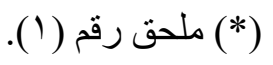

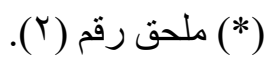




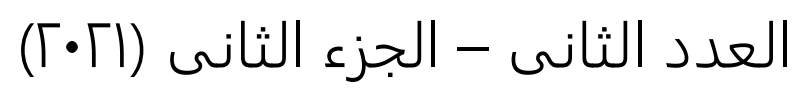
مجلة بحوث

"العلوم التربوية"

من بعضها ، وتتمثل هذه القدرات في (القدرة اللغُوية ، القدرة العددية ، الققرة الدكانية ، القدرة على الاستدلال

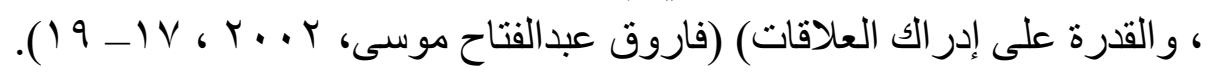

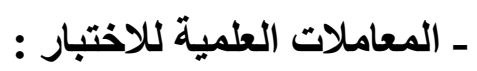

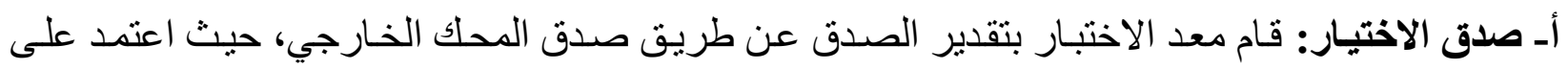

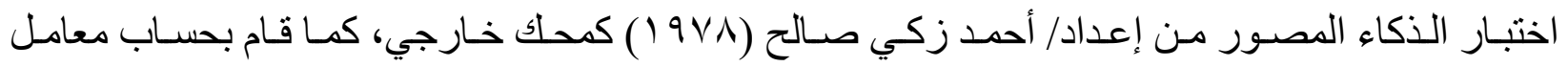

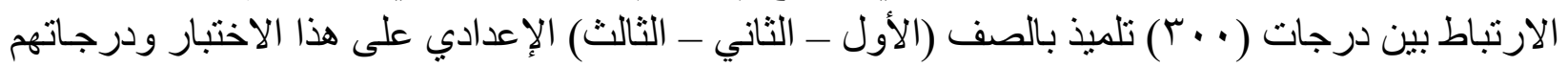

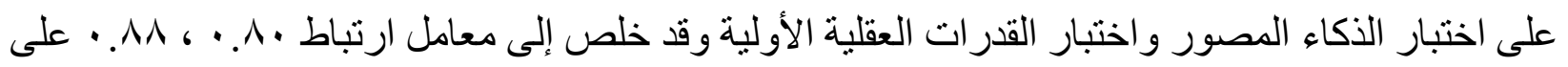

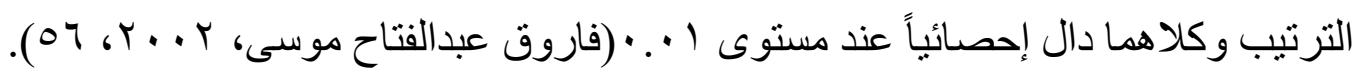

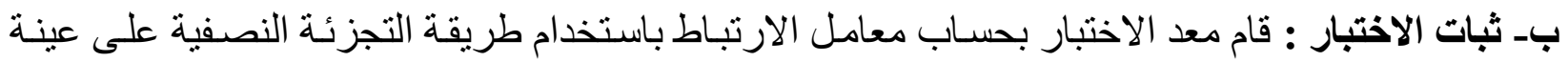

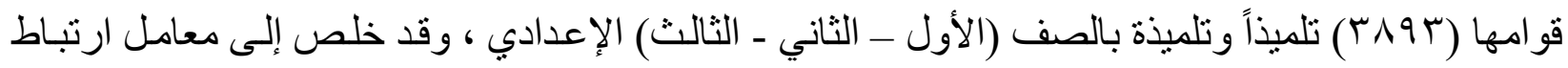

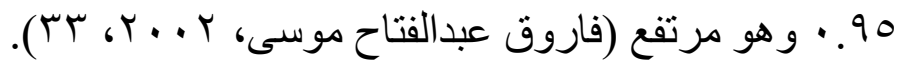
الكفاءة السيكومترية في الدراسة الحالية:

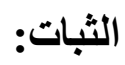

ـ التجزئة النصفية: واعتمد الباحث الحالي في حساب معامل ثبات الاختبار على طريقة التجزئة النصفية،

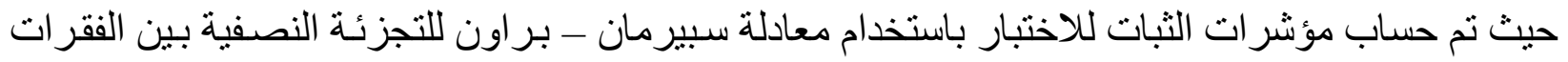

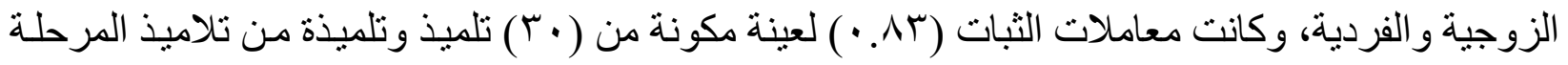

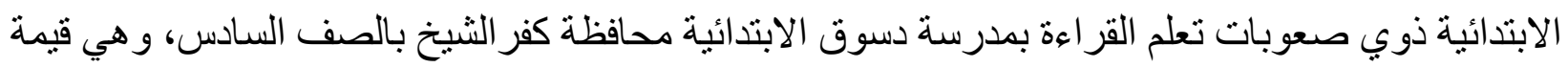
مناسبة للتحقق من ثبات الاختبار. ـ معادلة ألفا كرونباخ: وباستخدام معادلة ألفا كرونباخ توصل الباحث إلى معامل ارتباط إي. ، ، وهي دالة

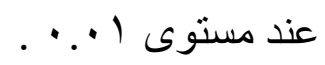

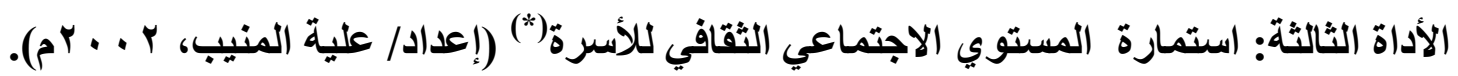

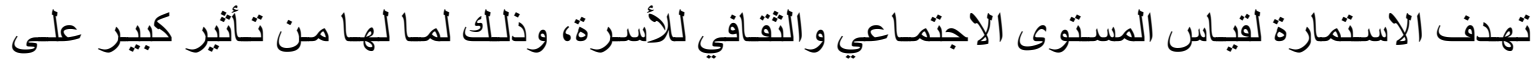

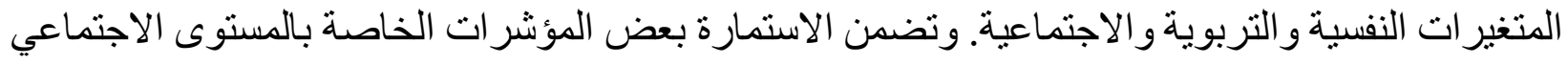

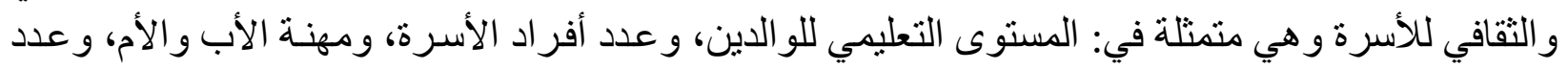

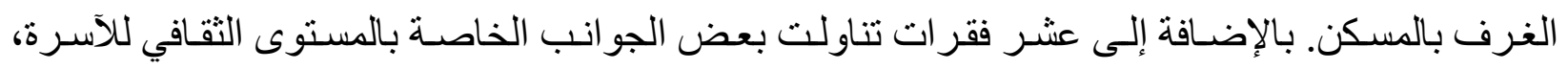
حساب الثبات لاستمارة المستوى الاجتماعي الثقافي للأسرة:

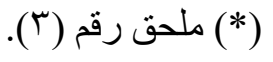




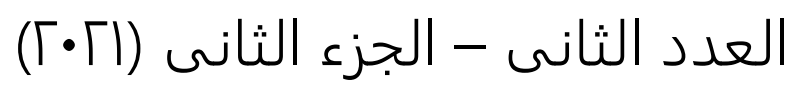
مجلة بحوث

"العلوم التربوية"

قام الباحث بحساب ثبات لاستمارة المستوى الاجتماعي الثقافي للأسرة بطريقتين هما آلفا كرونباخ

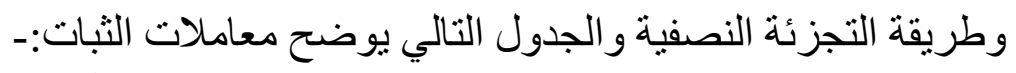
جدول (•) معاملي ثبات لاستمارة المستوى الاجتماعي الثقافي للأسرة

\begin{tabular}{|c|c|c|}
\hline التجزئة النصفية (سبيرمان براون) & معامل آلفا كرونباخ & البعد \\
\hline$\quad \cdot 7 \Lambda$ &. $\mathrm{VV}$ & اجتماعي \\
\hline .07 & $\cdot . \wedge r$ & ثقافي \\
\hline$\cdot . \vee \varepsilon$ &. .19 & الدرجة الكلية \\
\hline
\end{tabular}

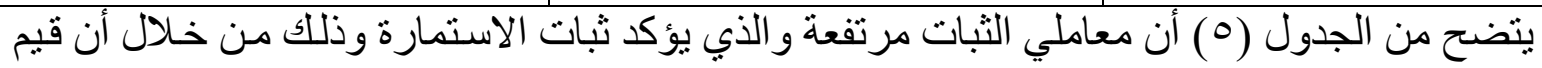

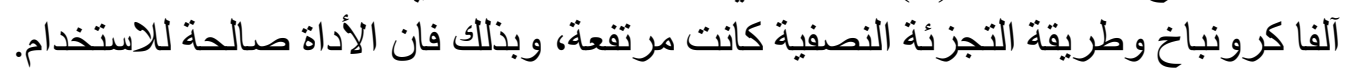

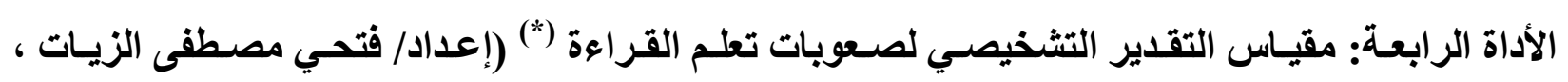
(r...V

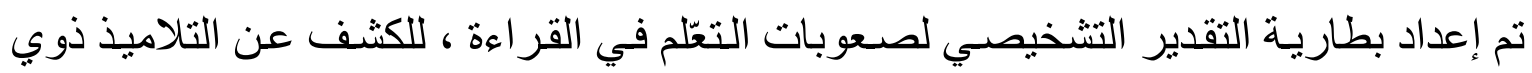

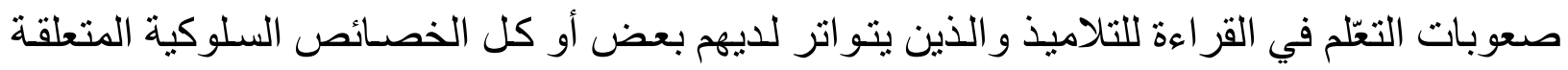

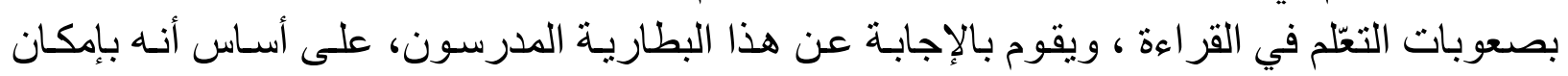

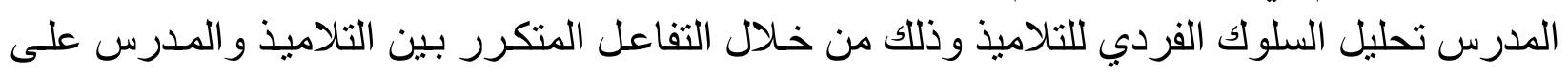

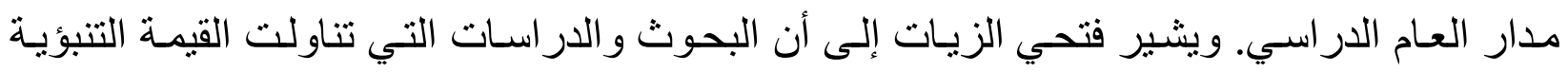

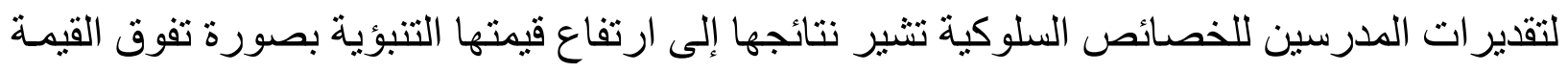
التنبؤية لاختبار ات الذكاء المقننة.

صدق وثبات بطاريه تثخيص صعوبات التعلم:

• حساب الصدق: تم اعتماد عدة طرق في حساب الصدق، وتثمل صددق المحتوى حيث تم استخدام

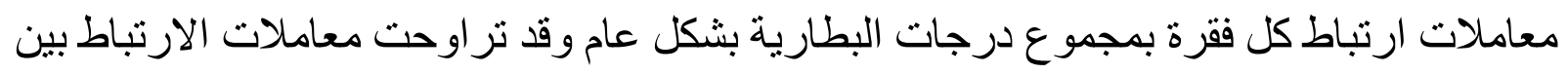

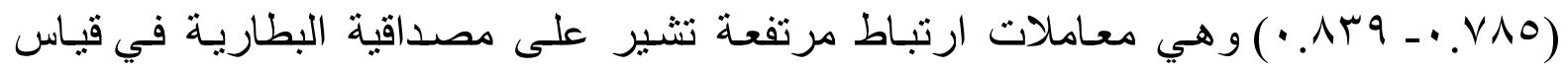

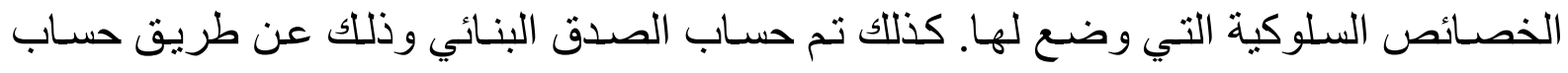

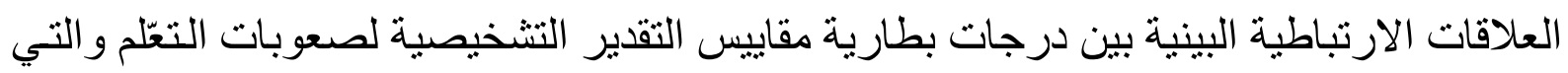

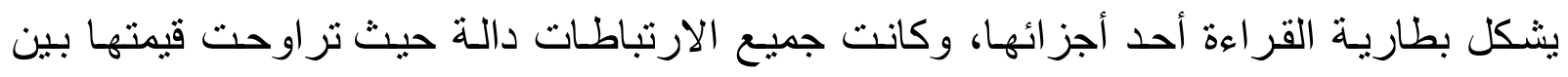

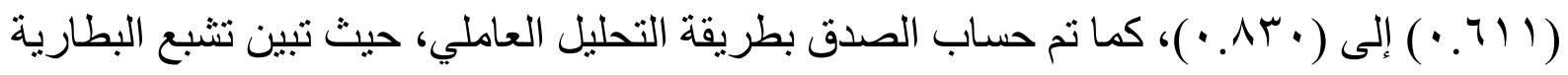

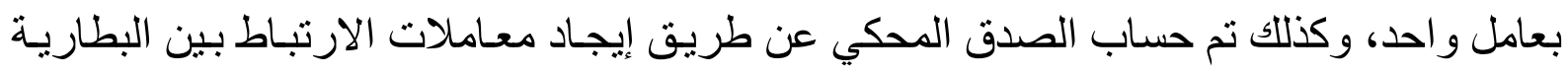

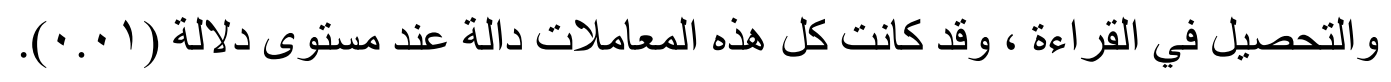

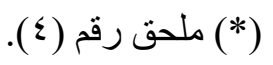




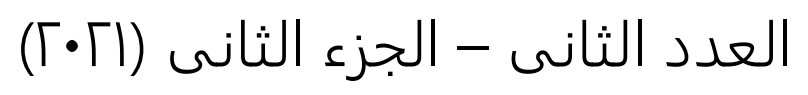

مجلة بحوث

"العلوم التربوية"

• حساب الثبات: تم حساب ثبات البطارية بمعادلة إلفا كرونباخ وقد بلغت (990 . •)، أمـا الطريقـة

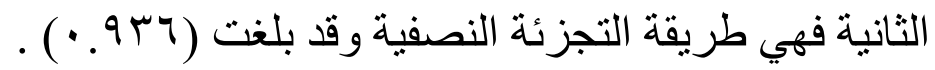
في الدراسة الحالية:اتبع الباحث الإجر اءات التالية:

صدق البطاريـة: تم حسـاب صدق المحتوى حيث استخدم معاملات الارتباط بين كل فقرة

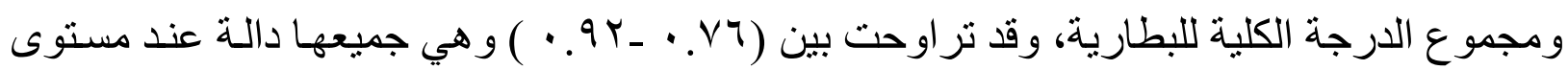

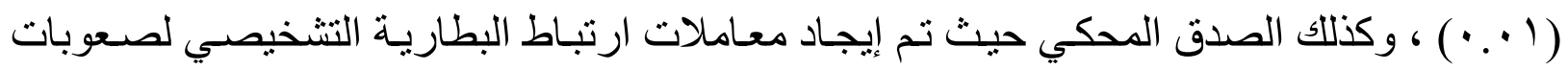

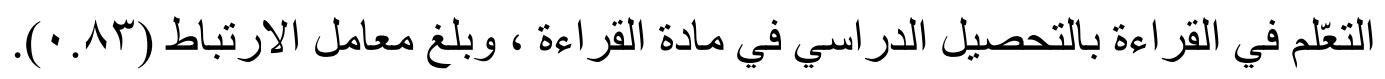

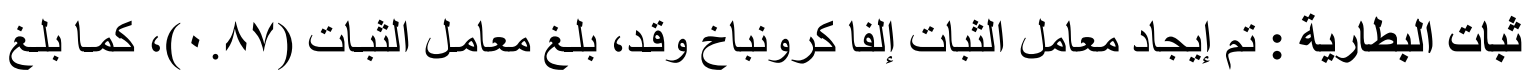

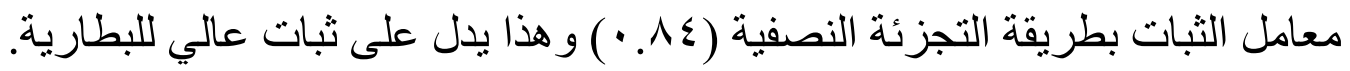

الأداة الخامسة: مقياس عادات العقل لدي تلاميذ المرحلة الابتدائية ذوي صعوبات تعلم القراءة(") (إعداد/ الباحث).

ويُعرّف الباحث عادات العقل إجر ائياً بأنها خصائص منطقية يتميز بها بعض الناس وتمثنل مجمو عـة

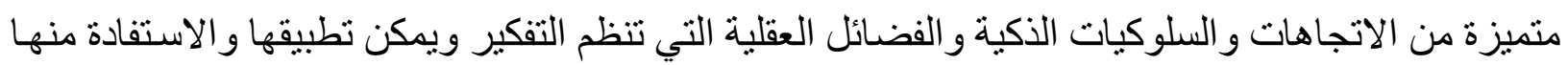

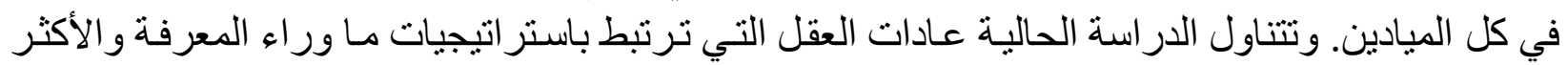

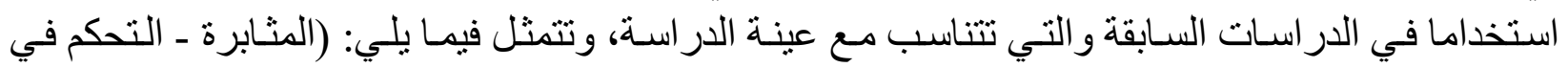

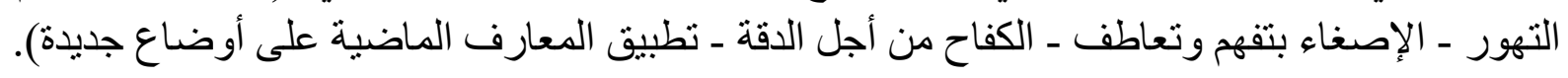

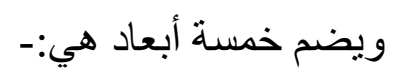

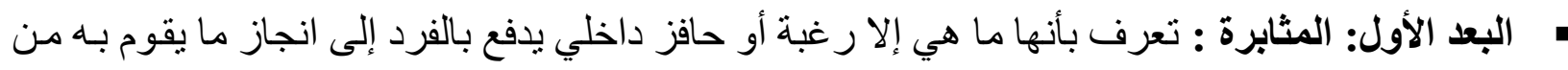

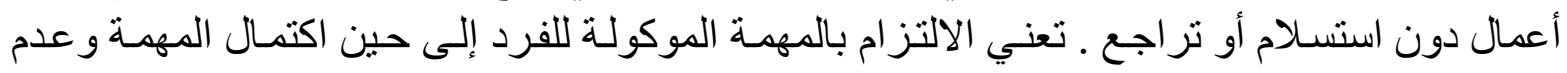

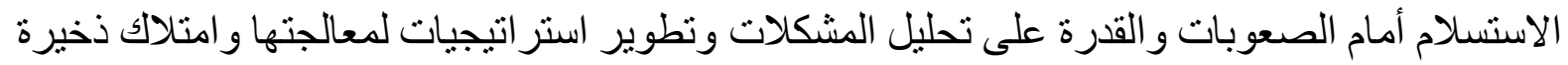
مختزنة من الاستر اتيجيات البديلة لحل المشكلة التي يتبعها شعور بالر احسة. ويتكون هذا البعد من (10) عبارة.

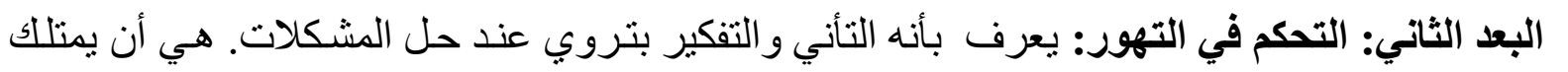

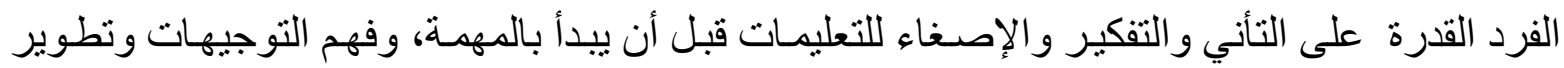

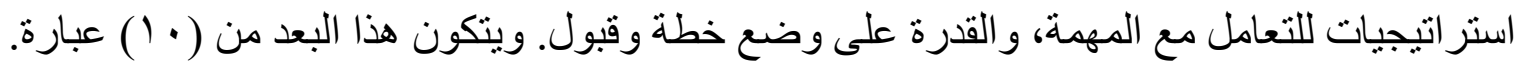

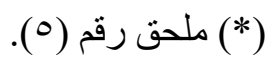




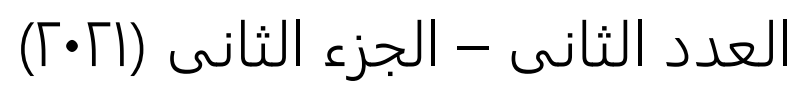
مجلة بحوث

"العلوم التربوية"

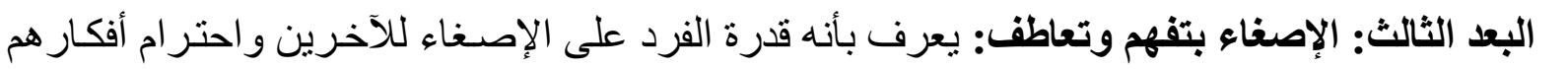

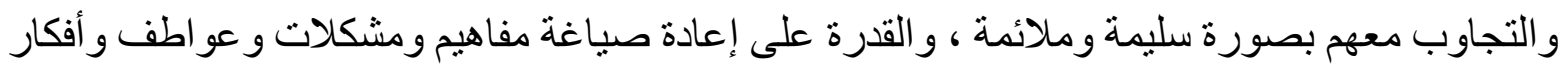

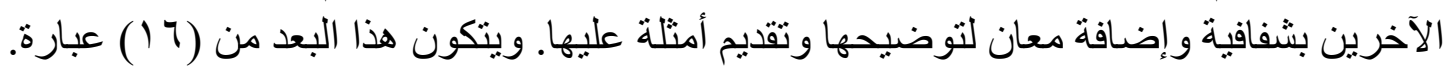

• البعد الرابع: الكفاح من أجل الدقة: يعرف بأنه قدرة الفرد على العمل المتو اصل بحرفية و إتقان وتفحص

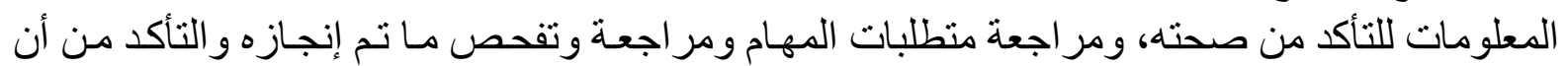

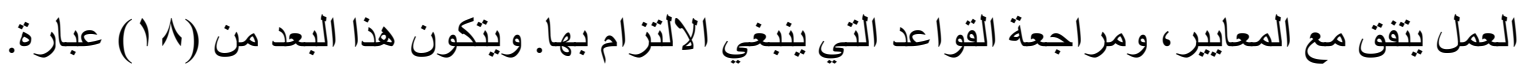
• البعد الخامس: تطبيق المعارف الماضية على أوضاع جديدة: تعرف بأنها نطبيق المعارف الماضية

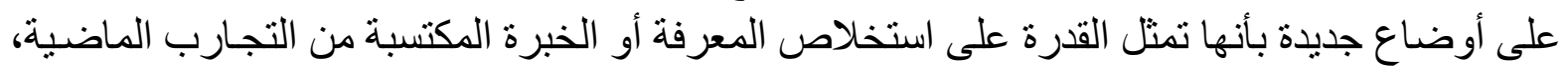

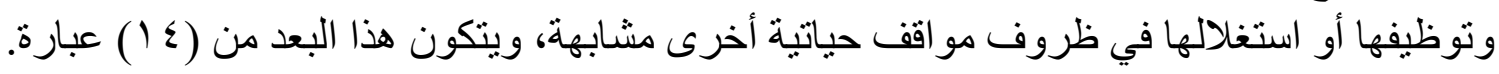
ولتصـميم مقيـاس عـادات العقل لدى تلاميذ المرحلـة الابتدائيـة ذوي صـوبات التعلم قـام الباحث

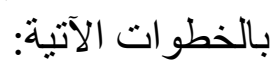

الخطوة الأولى: استقراء التراث النظري الخاص بمفهوم عادات العقل:

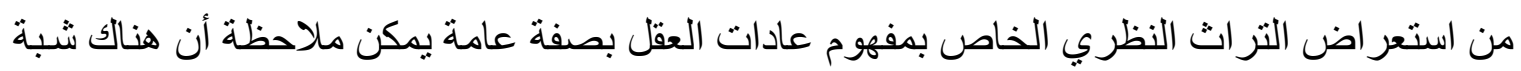

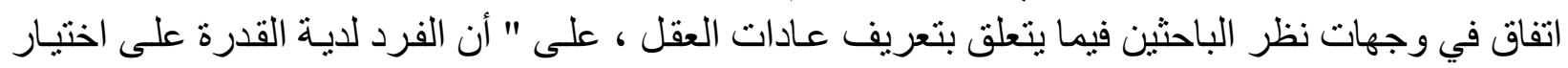

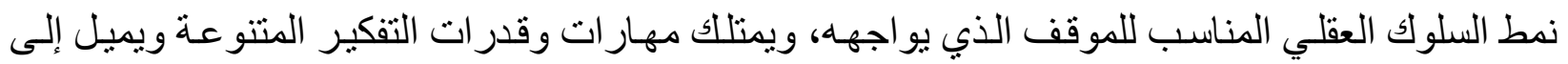

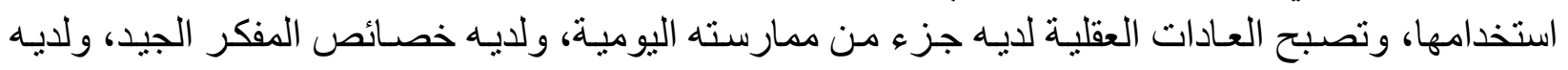

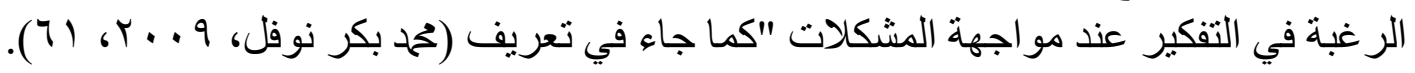

الخطوة الثانية: الإطلاع على بعض المقاييس ذات الصلة بالموضوع وهي على النحو التالي:

تم الإطلاع على عدد من المقاييس التي تناولت عادات العقل، منها ما يلي:-

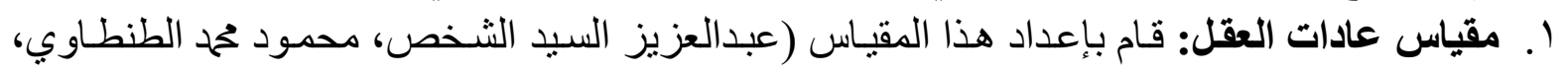

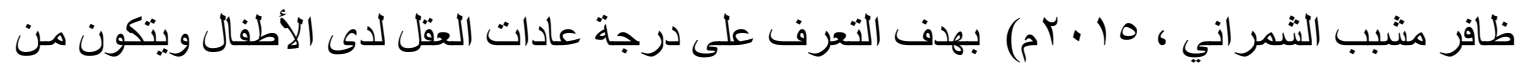

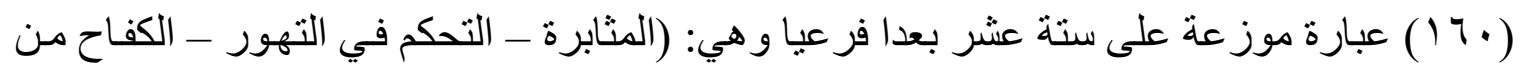

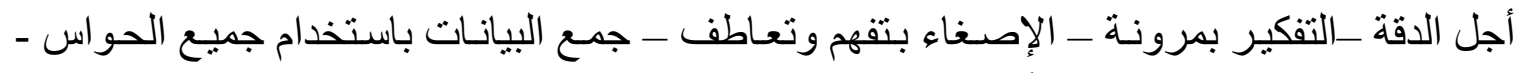

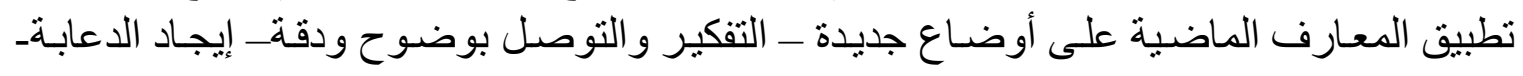

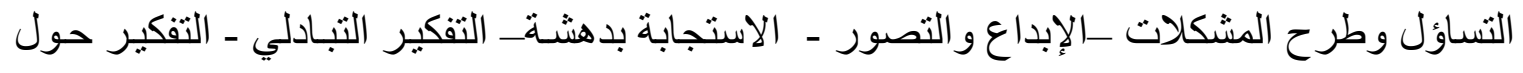
التفكير - تحمل المسؤولية والإقدام على المخاطر - الاستعداد الدائم للتعلم). 


$$
\text { "العلوم التربوية " مجلةث }
$$

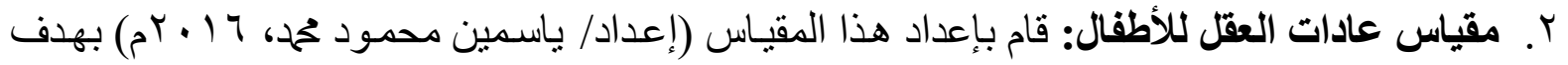

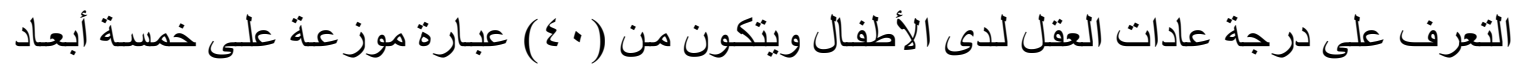

$$
\begin{aligned}
& \text { البعد الأول (المثابرة) ويتكون من (0) عبارة. } \\
& \text { فر عية وهي: - مئي }
\end{aligned}
$$

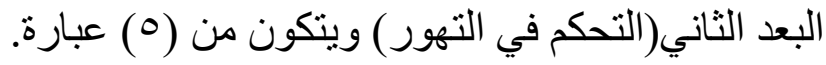

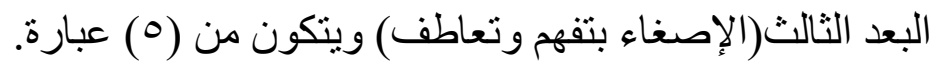

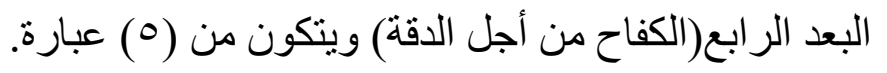

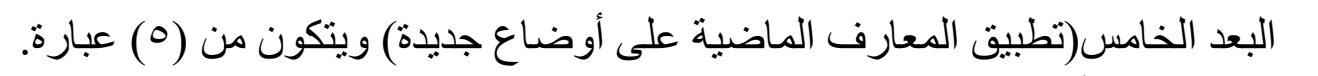

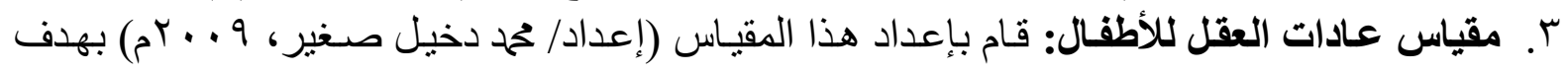

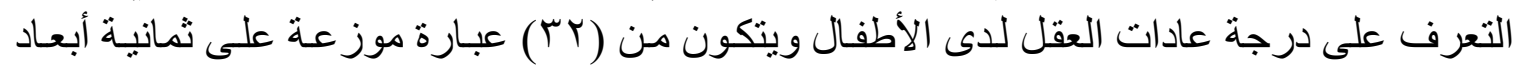

البعد الأول (المثنابرة) ويتكون من (0) عبارة.

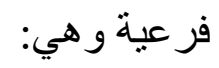

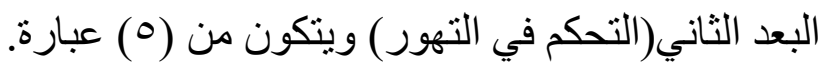

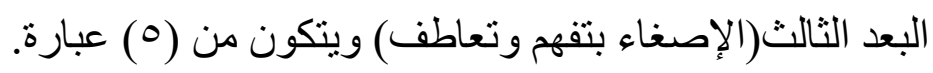

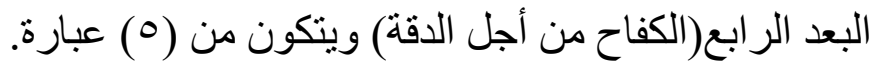

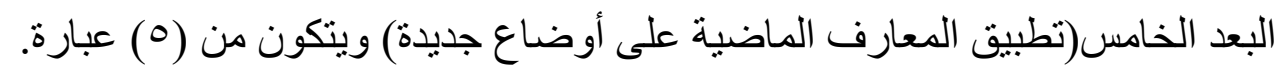

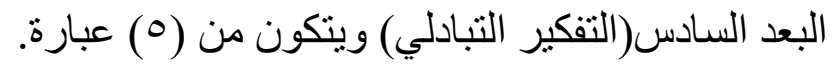

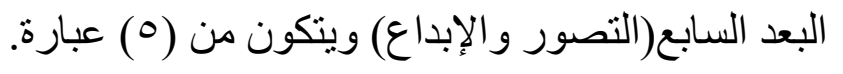

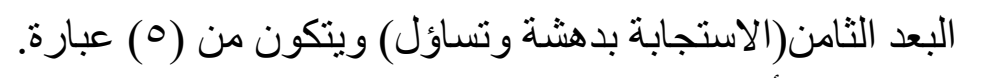

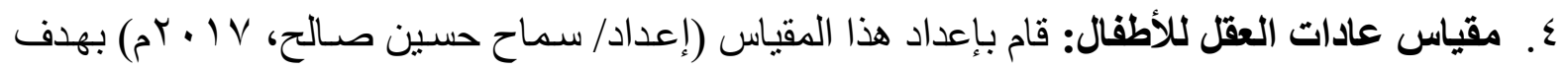

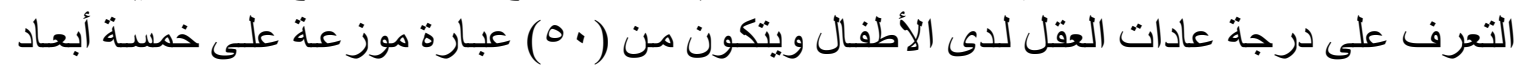

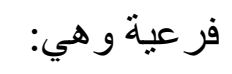

• البعد الأول (المثابرة) ويتكون من (• (1) عبارة.

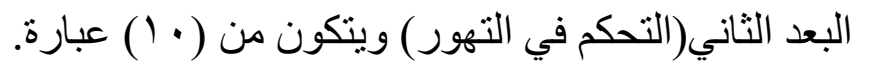

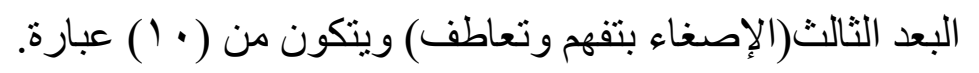

البعد الر ابع(الكفاح من أجل الدقة) ويتكون من ( • ( ) عبارة.

البعد الخامس(تطبيق المعارف الماضية على أوضاع جديدة) ويتكون من ( • ( ) عبارة.

الخطوة الرابعة: إعداد المقياس في صورته الأولية

من خلال الاطلاع النظري و الدر اسات السابقة و المقاييس الخاصة بمقياس عادات العقل أمكن للباحث

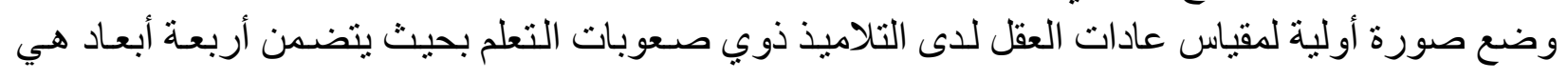




$$
\text { "العلوم التربوية " مجلةث }
$$

(المثابرة ـ التحكم في التهور ـ الإصغاء بتفهم وتعاطف ـ الكفاح من أجل الدقة ـ تطبيق المعارف الماضية

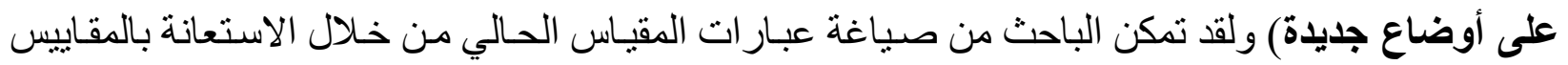

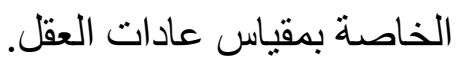

وفيما يلي وصف المقياس في صورته الأولية: تكون المقياس من (VT) عبارة موز عة على ثلاثنة

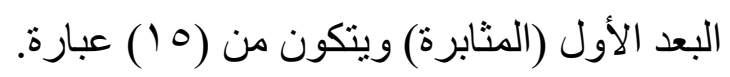

البعد الثاني (التحكم في التهور ) ويتكون من ( • ( ) عبارة.

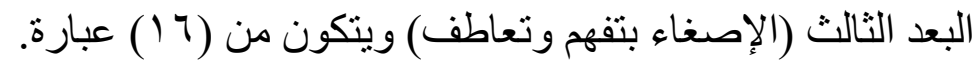

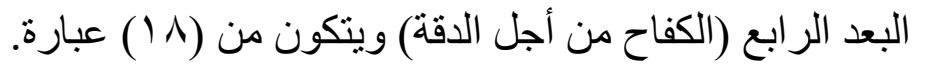

البعد الخامس(تطبيق المعارف الماضية على أوضاع جديدة) ويتكون من (ع (1) ) عبارة.

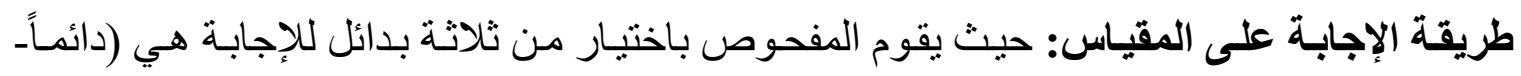

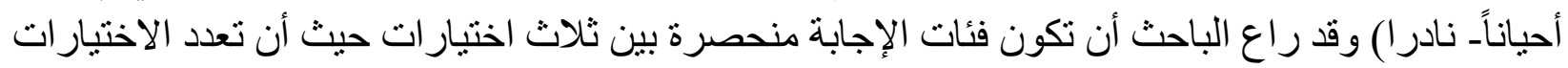

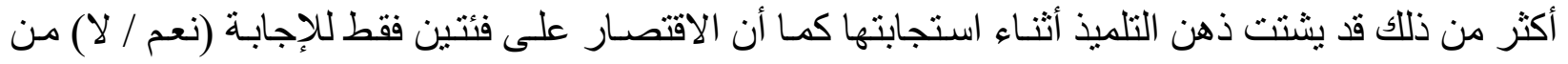
شأنه أن يقيد المفحوص بإجابة محددة قد لا تكون معبرة عنه.

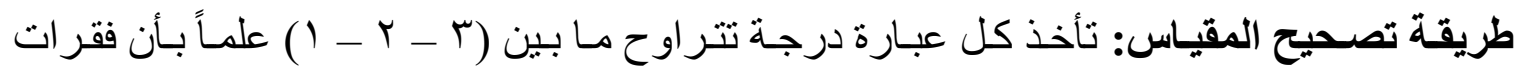

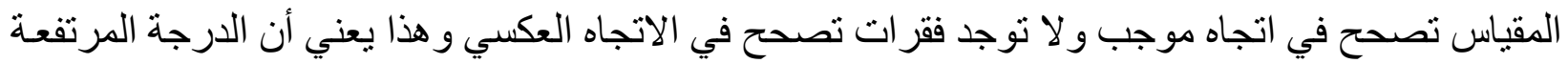

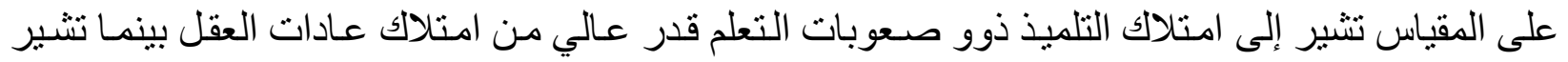

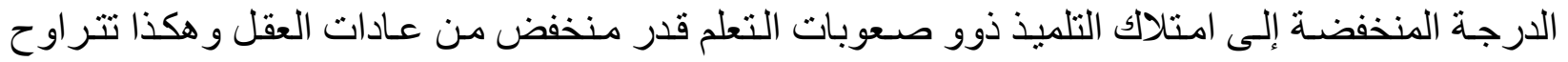

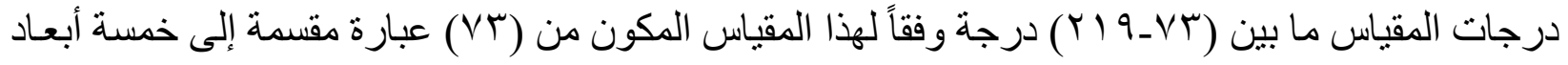

\begin{tabular}{|c|c|c|c|}
\hline العبارات & عدد العبارات & الأبعاد & م \\
\hline $10-1$ & 10 & المثابرة & . \\
\hline ro-14 & 1. & التحكم في التهور & r \\
\hline \&l-rq & 19 & الإصغاء بتفهم وتعاطف & \\
\hline ه Q_k r & in & الكفاح من أجل الدقة & \{ \\
\hline vrיד. & $1 \varepsilon$ & تطبيق أوضاع جليدة الماضية & 。 \\
\hline \multicolumn{2}{|r|}{ Vب ع ع ع ع } & \multicolumn{2}{|c|}{ ل ل ل لإجمالي } \\
\hline
\end{tabular}

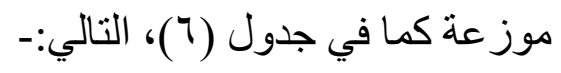

جدول (ך) عادات مقياس عادات العقل وعباراته في الصورة الأولية 

العدد الثانى - الجزء الثانى (IГ•「)
مجلة بحوث
"العلوم التربوية"

\section{الخطوة الخامسة: التحقق من الكفاءة السيكومترية لمقياس عادات العقل:}

للتحقق من الكفاءة السيكومترية لمقياس عادات العقل للى التلاميذ ذوي صعوبات التعلم قام الباحث

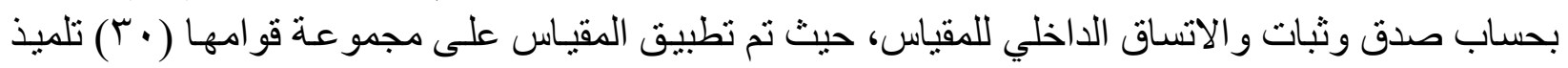

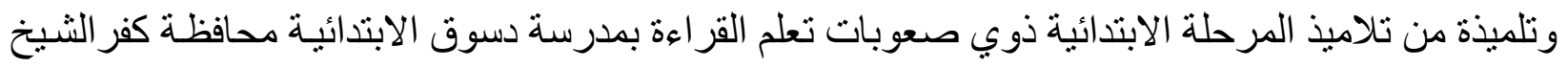

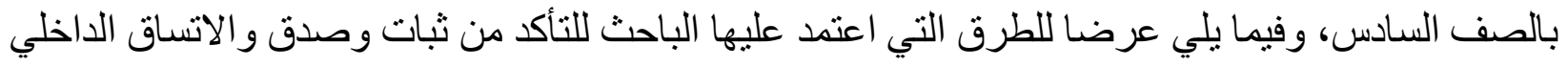
للمقياس.

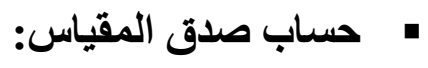

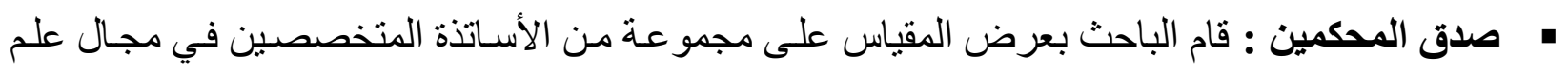

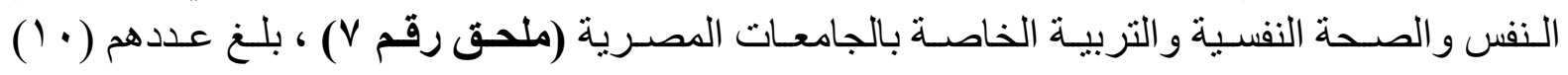

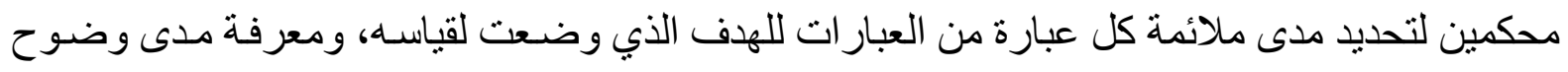

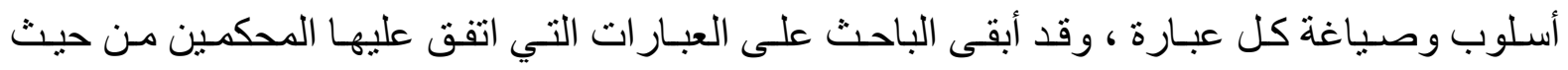

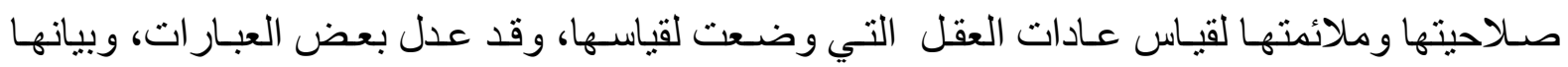

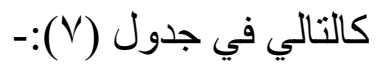

\begin{tabular}{|c|c|c|c|}
\hline العبارة بعد التعديل & العبارة قبل التعديل & 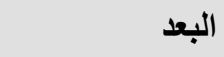 & رقم العبارة \\
\hline اعمل بجد للحصول على أعلى الدرجات & \multirow{2}{*}{ أعلى الارجل بجد ونشـاط للحصول على } & \multirow[t]{4}{*}{ 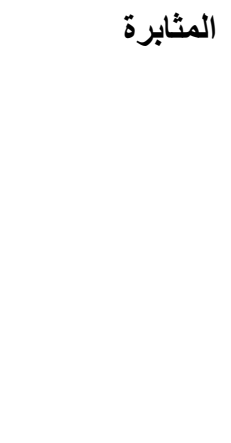 } & \multirow[t]{2}{*}{1} \\
\hline اعمل بنشاط للحصول على أعلى الدرجات & & & \\
\hline أحفز نفسي على أداء واجبي المنزلي & الحفزل نفسي على أداء واجبي & & $r$ \\
\hline أحب أنجاز الأعمـال التي يعتقد الآخرون & أحب الجـاز الأعمـال التـي يعتقد & & 11 \\
\hline أفكر طويلا قبل أداء النشـاط & أفكر طويلا قبل أن أتصرف & \multirow[t]{2}{*}{ التحكم في التهور } & 10 \\
\hline أقرا الأسئلة قراعة متأنيـة قبل البداء في & ققرا المسائل والأسئلة قراءة متأنية & & $r \leqslant$ \\
\hline أتعاطف تجاه مشاعر الآخرين & \multirow{2}{*}{ أتعـاطف تجـاه مشــاعر وقـرات } & \multirow{3}{*}{ وتعاطف الاصغاء بتقهز } & \multirow[t]{2}{*}{ rr } \\
\hline أتعاطف تجاه قدرات الآخرين & & & \\
\hline استمع جيدا للمعلم & استمع جيدا للمعلم وأفكر فيمـا يقول & & $r \cdot$ \\
\hline
\end{tabular}

$-1 V \cdot-$ 


$$
\text { "العلوم التربوية " مجلةث }
$$

\begin{tabular}{|c|c|c|c|}
\hline العبارة بعد التعديل & العبارة قبل التعديل & البعد البع & رقم العبارة \\
\hline أفكر فيما يقول المعلم & 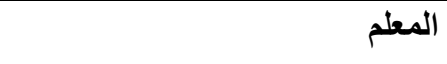 & & \\
\hline أثشارك الآخرين مشاعرهم & 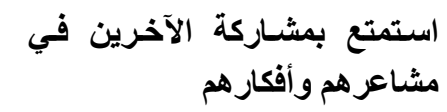 & & rv \\
\hline التزم الدقة في عملي & اشعر بالدقة عندما أتقن عملي & \multirow{3}{*}{ الالدقةح من أجل } & $\leqslant 0$ \\
\hline أراعي الدقة عند الحل & \multirow[t]{2}{*}{ أراعي الدقة والسرعة عند الحل } & & 01 \\
\hline أراعي السرعة عند الحل & & & \\
\hline جديدة المعلومـات المتعلمـة في مواقف & مواقف جديدة استخدمـات المتعلمة في & \multirow{3}{*}{ أطبيق المعارفية على المضاع جديدة } & ov \\
\hline أستجل سلبيات أدائسي في العام الماضسي & \multirow{2}{*}{ أسجل سلبيات وايجابيات أدائي في العالمي العاضي } & & 7. \\
\hline أسجتل ايجابيـات أدائسي في العام الماضـي & & & \\
\hline
\end{tabular}

وبذلك أصبح المقياس مكون من (VT) عبارة تحت خمسة عادات. كما في جدول (^) التالي:-

\begin{tabular}{|c|c|c|c|}
\hline العبارات & عدد العبارات & الأبعاد & م \\
\hline 10.1 & 10 & المثابرة & .7 \\
\hline ro-17 & 1. & التحكم في التهور &.$v$ \\
\hline$\leq 1-r q$ & 18 & الإصغاء بتفهم وتعاطف &.$\wedge$ \\
\hline$\Delta q_{-} \leqslant r$ & 11 & الكفاح من أجل الدقة & .9 \\
\hline Vr-q. & $1 \leqslant$ & تطبيق أوضاع جليدة المعارف الماضية & .1 . \\
\hline \multicolumn{2}{|r|}{ عبارة VT } & \multicolumn{2}{|c|}{ الإجمالي } \\
\hline
\end{tabular}

جدول (^) أبعاد مقياس عادات العقل وعباراته في الصورة النهائية

• صدق المحك: باستخدام طريقة صدق المحك حيث كانت معامل الارتباط بين درجات (·r) تلميذ وتلميذة

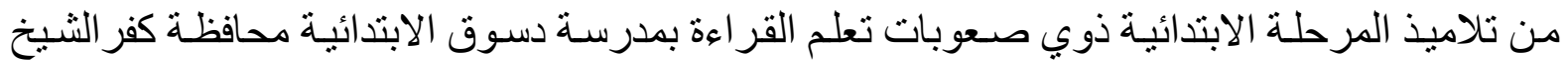

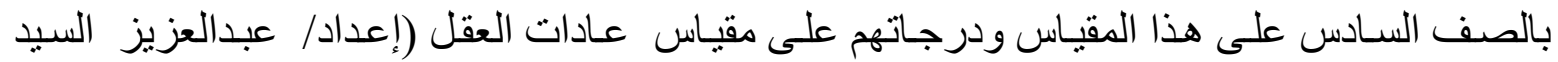

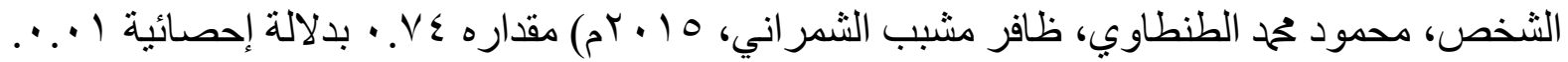

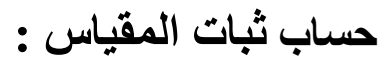




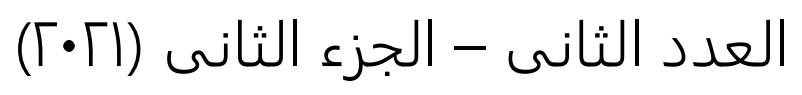

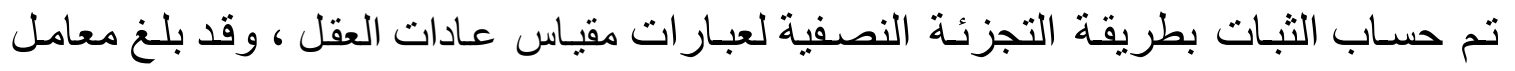

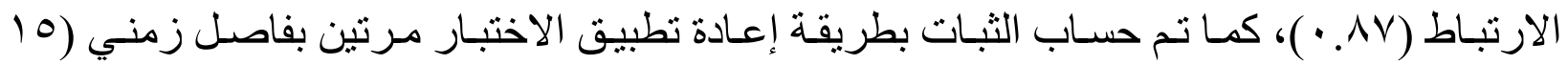

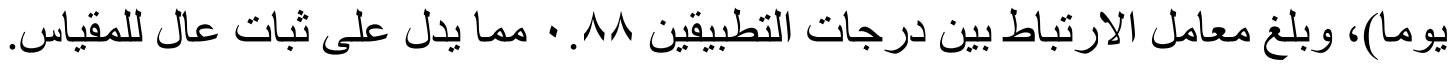
حساب الاتساق الا|خلي للمقياس: تم حساب ارتباط درجة البند مع درجة البعد الذي ينتمي إليه، وجاءت النتائج كمـا هي موضحة

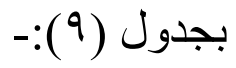
جدول (9) الاتساق الاخلي لمفردات مقياس عادات العقل لتلاميذ ذوي صعوبات التعلم مع الدرجة الكلية للبعد

\begin{tabular}{|c|c|}
\hline \multicolumn{2}{|c|}{ تطبيق أوضاع المعارف الماضيدة } \\
\hline معامل الارتباط & رقم البند \\
\hline$* *, . V \leqslant$ & 7. \\
\hline **. & 71 \\
\hline$* *, V V$ & Tr \\
\hline$* * .00$ & rT \\
\hline$* * .71$ & $7 \varepsilon$ \\
\hline$* * ., 11$ & 70 \\
\hline$* * .94$ & 79 \\
\hline$* *, \Lambda_{1}$ & $7 \mathrm{~V}$ \\
\hline$* * . V V$ & 71 \\
\hline$* *$. Tr & 79 \\
\hline$* * .77$ & v. \\
\hline$* *, . \wedge V$ & vi \\
\hline$* * . \vee \vee 7$ & VY \\
\hline$* * . .71$ & $v r$ \\
\hline & \\
\hline & \\
\hline
\end{tabular}

\begin{tabular}{|c|c|}
\hline من أجل & الألفة الة \\
\hline معامــــــــل & رقّــ \\
\hline الارتباط & البند \\
\hline$* * . \vee 9$ & $\varepsilon Y$ \\
\hline$* * . .7 V$ & $\varepsilon$ \\
\hline$* * .70$ & $\varepsilon \varepsilon$ \\
\hline$* * . \vee \Lambda$ & $\varepsilon 0$ \\
\hline$* *, . \wedge \wedge$ & $\varepsilon 7$ \\
\hline$* * . .7 V$ & $\varepsilon V$ \\
\hline$* * . V V$ & $\varepsilon \wedge$ \\
\hline$* * . .7 \%$ & $\varepsilon q$ \\
\hline$* * . \Lambda \Lambda$ & 0. \\
\hline$* * . .7 V$ & 01 \\
\hline$* * .70$ & $\Delta r$ \\
\hline$* * . \vee \vee q$ & H \\
\hline$* * . V Y$ & $0 \leq$ \\
\hline$* * .94$ & 00 \\
\hline$* * . V V$ & 07 \\
\hline$* * .71$ & $\Delta V$ \\
\hline
\end{tabular}

\begin{tabular}{|c|c|}
\hline ع بتفهم & الإصــ \\
\hline 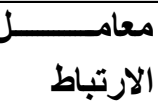 & رقاتلدم \\
\hline$* * .71$ & rq \\
\hline$* * . .07$ & rV \\
\hline$* * . .7$ & Y^ \\
\hline$* * . . \diamond V$ & rq \\
\hline$* * . .09$ & r. \\
\hline$* * . \vee \vee q$ & ו \\
\hline$* *, . \vee \varepsilon$ & rr \\
\hline$* * . .71$ & سب \\
\hline$* * .7 \pi$ & r \\
\hline$* * . \wedge 0$ & po \\
\hline$* * . .7 r$ & rq \\
\hline$* *, V V$ & $\mu v$ \\
\hline$* * . . \Delta V$ & $\mu \wedge$ \\
\hline$* * .71$ & rq \\
\hline$* * . \wedge 1$ & $\varepsilon$. \\
\hline$* * .9 r$ & $\varepsilon 1$ \\
\hline
\end{tabular}

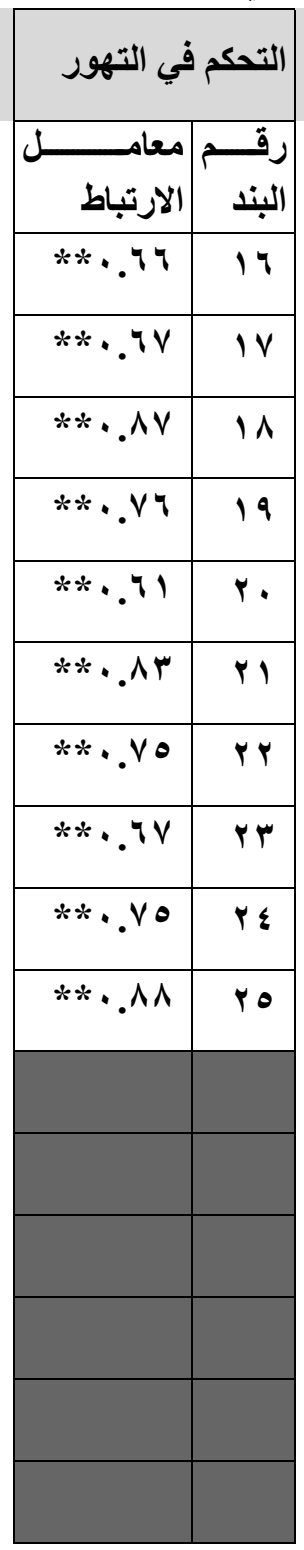

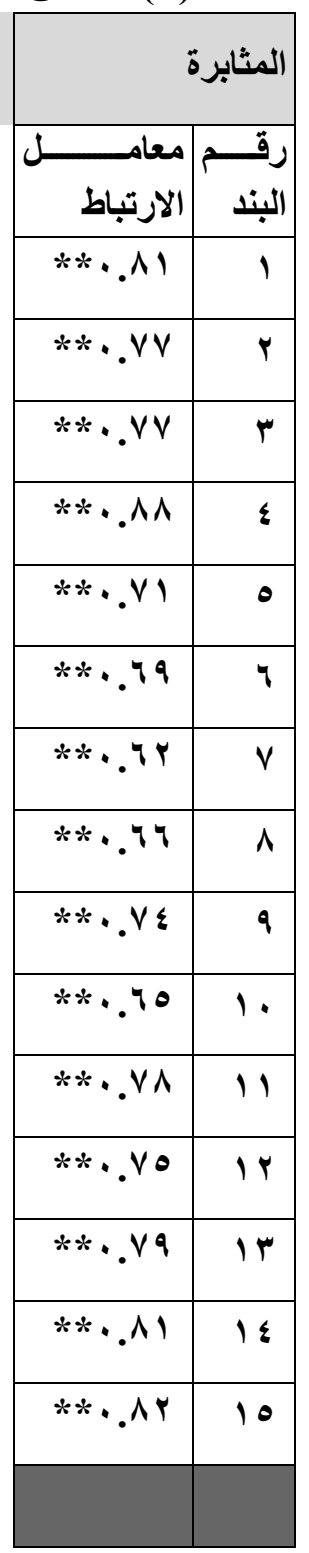




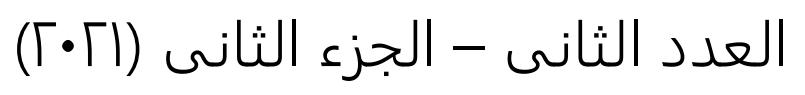

مجلة بحوث

"العلوم التربوية" مجولة "
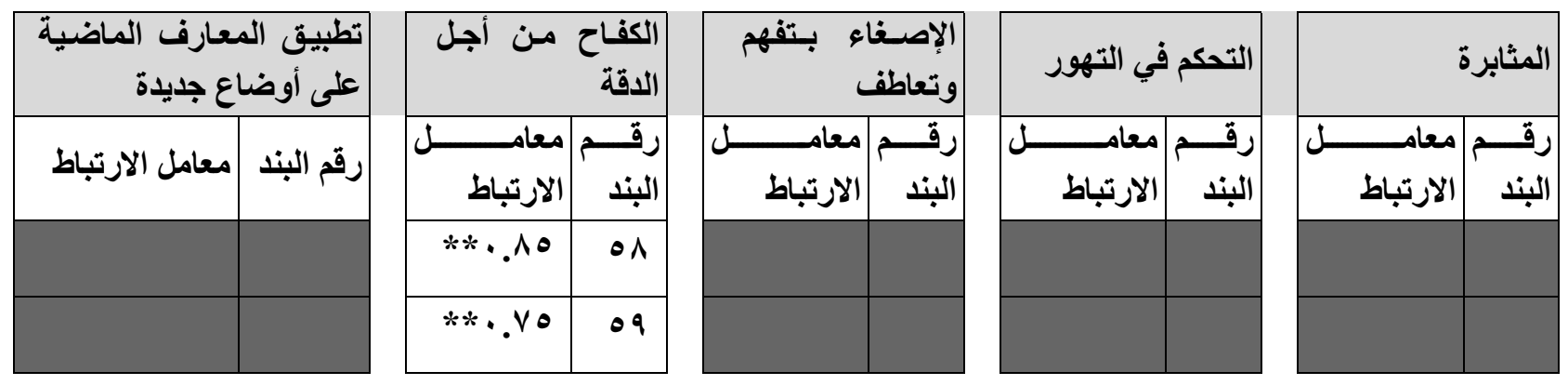

(**) جميع القيم دالة عذد مستوى 1 +.

كما تم حساب ارتباط العبارة مع الدرجة الكلية للمقياس: ويوضح الجدول ( • ( ) نتائج هذا الإجر اء:

جدول (• 1) الاتساق الداخلي لمفردات مقياس عادات العقل للتلاميذ ذوي صعوبات التعلم مع الدرجة الكلية للمقياس

\begin{tabular}{|c|c|c|c|}
\hline الارتباط معامـلـل & 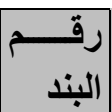 & 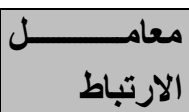 & 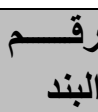 \\
\hline$* *, . V \leq$ & $\left({ }^{0}\right)$ & $* * .71$ & (\&) \\
\hline$* * . .7 \leq$ & $(1 \cdot)$ & $* * . .77$ & (9) \\
\hline$* * . . \wedge V$ & $(10)$ & $* * .71$ & $(1 \leq)$ \\
\hline$* * . . \wedge \mathrm{V}$ & $(Y \cdot)$ & $* * ., \wedge \wedge$ & $(19)$ \\
\hline$* * ., \wedge \wedge$ & $\left(Y^{\theta}\right)$ & $* * . \Delta \wedge$ & $(Y \varepsilon)$ \\
\hline$* * . . \wedge V$ & $(\mu \cdot)$ & $* * . .7 V$ & $\left(Y^{q}\right)$ \\
\hline$* * . . V Y$ & $\left(\mu^{\mu}\right)$ & $* * . . \vee \wedge$ & $(\mu \varepsilon)$ \\
\hline$* * . . \vee 1$ & $(\varepsilon \cdot)$ & $* * . .74$ & $\left(p^{p q}\right)$ \\
\hline$* * . . \vee 7$ & $(\leqslant 0)$ & $* * . . \wedge V$ & $(\varepsilon \varepsilon)$ \\
\hline$* * . .77$ & $(0 \cdot)$ & $* * .7 \mathrm{~V}$ & $(\leqslant 9)$ \\
\hline$* * .71$ & $(00)$ & $* * . .71$ & $(0 \leq)$ \\
\hline$* * . . \wedge \mathrm{V}$ & $(7 \cdot)$ & $* * . . V V$ & $(09)$ \\
\hline$* * . . V V$ & $(70)$ & $* *, . V V$ & ( $7 \varepsilon)$ \\
\hline$* * .7 \pi$ & $(V \cdot)$ & $* * .94$ & $(79)$ \\
\hline & & & \\
\hline
\end{tabular}

\begin{tabular}{|c|c|}
\hline الارتباط & رالبند \\
\hline$* *, . V V$ & (r) \\
\hline$* * . . \Delta V$ & $\left({ }^{\wedge}\right)$ \\
\hline$* * . . T V$ & $(1 T)$ \\
\hline$* *, . V V$ & $(1 \wedge)$ \\
\hline$* * . . \Delta V$ & $\left(Y^{\mu}\right)$ \\
\hline$* *, . V V$ & $\left(Y^{\wedge}\right)$ \\
\hline$* *, . \wedge \varepsilon$ & $(r r)$ \\
\hline$* *, .71$ & $(\mu \wedge)$ \\
\hline$* *, . \wedge r$ & $(\varepsilon \Psi)$ \\
\hline$* *, . \wedge \Lambda$ & $(\varepsilon \wedge)$ \\
\hline$* * . .41$ & $\left(\theta^{\prime}\right)$ \\
\hline$* *, . V V$ & $(\theta \wedge)$ \\
\hline$* * . . T V$ & (Tr) \\
\hline$* * .77$ & $(7 \wedge)$ \\
\hline **, \ & $\left(V^{\top}\right)$ \\
\hline
\end{tabular}

\begin{tabular}{|c|c|}
\hline 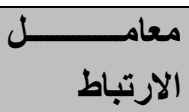 & رقات \\
\hline$* *, . \wedge 0$ & $\left({ }^{r}\right)$ \\
\hline$* *, . \vee \neg$ & (V) \\
\hline$* *, . \wedge \varepsilon$ & $(I Y)$ \\
\hline$* *$, . Vo & (IV) \\
\hline$* * . .7 \mathrm{~V}$ & $\left(Y^{Y}\right)$ \\
\hline$* *, . \wedge r$ & $(Y V)$ \\
\hline$* *, . \wedge 0$ & $\left(Y^{r}\right)$ \\
\hline$* *, V Y$ & $(r v)$ \\
\hline$* *$, . Vo & $(\varepsilon r)$ \\
\hline$* *, . \wedge r$ & $(\varepsilon V)$ \\
\hline$* *$. 7 \& & $(\Delta r)$ \\
\hline$* * . .79$ & $(\Delta V)$ \\
\hline$* * ., T Y$ & (Yr) \\
\hline$* * . . V r$ & $(7 V)$ \\
\hline$* *, V V$ & $(V Y)$ \\
\hline
\end{tabular}

\begin{tabular}{|c|c|}
\hline معامـ الارتباط & رإندم \\
\hline$* * . . V 1$ & (1) \\
\hline$* * . . V r$ & (7) \\
\hline$* * . .70$ & (11) \\
\hline$* *, . \vee \wedge$ & (17) \\
\hline$* * . \wedge 1$ & (YI) \\
\hline$* * . .79$ & $\left(Y^{Y}\right)$ \\
\hline$* * . .7 Y$ & (r) \\
\hline **. ד & ( \\
\hline$* * . V \varepsilon$ & $(\leqslant 1)$ \\
\hline$* *$. . $\vee 0$ & $(\leqslant 7)$ \\
\hline$* *, . \vee \wedge$ & $(01)$ \\
\hline$* *$, . $\vee 0$ & $(07)$ \\
\hline$* *$, . $\vee 0$ & (71) \\
\hline$* * . . \wedge 1$ & (77) \\
\hline$* * . \wedge \mu$ & (VI) \\
\hline
\end{tabular}

(*) جميع القيم دالة عند مستوى 1 •... 

العدد الثانى - الجزء الثانى (IГ•「)
مجلة بحوث
"العلوم التربوية"

كما تم حساب اتساق البعد مع الأبعاد الأخرى ومع الدرجة الكلية للمقياس: ويوضـح الجدول (1)

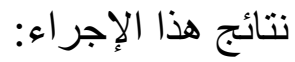
جدول (1 1) الاتساق الداخلي لأبعاد مقياس عادات العقل للتلاميذ ذوي صعوبات التعلم مع الدرجة الكلية

\begin{tabular}{|c|c|c|c|c|c|c|}
\hline الارجة الكلية & 0 & $\varepsilon$ & $r$ & r & 1 & الأبعاد \\
\hline & & & & & - & 1 \\
\hline & & & & - & $\cdot V \leqslant \varepsilon$ & r \\
\hline & & & - & $.0 \mathrm{~V} \varepsilon$ & $\cdot .7 \wedge \mu$ & $r$ \\
\hline & & - & .090 & $\because 0 \leqslant V$ & .074 & $\varepsilon$ \\
\hline & - & \& & Y & $.0 Y 1$ & .040 & 0 \\
\hline - & $\cdot . \wedge T r$ & $\cdot . \vee \wedge \theta$ & 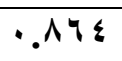 & . VOY & $\cdot . \wedge 11$ & اللارجة الكلية \\
\hline
\end{tabular}

يتضح من الجداول الثثلاثة أن المقياس يتمتع بدرجة من الاتسـاق الداخلي جيدة حيث جاءت

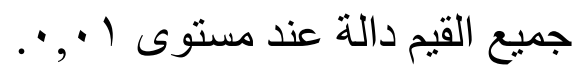
و على ذلك يكون الباحث قد تأكد من صدق وثبات المقياس و الاتسـاق الداخلي بطرق متنو عـة مما يجعل استخدامه مناسباً وملائماً. خطوات البحث : تم إجراء البحث وفقاً للخطوات التالية:

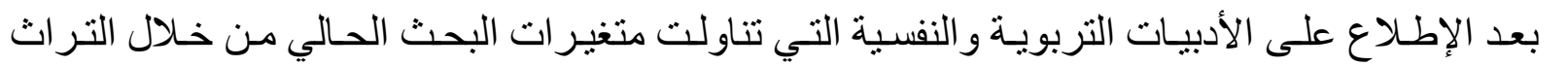

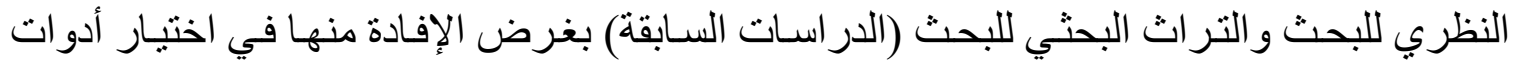

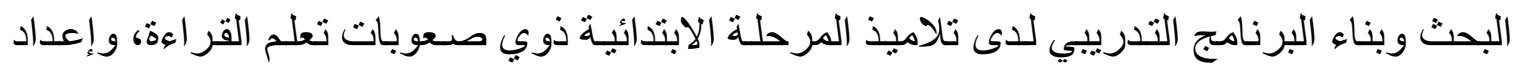

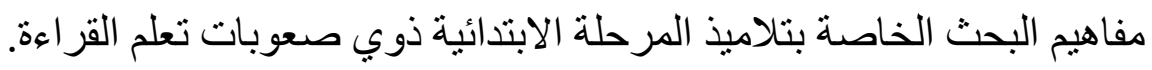

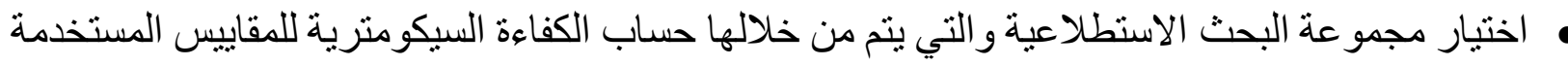

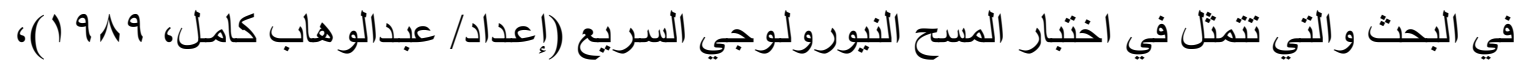

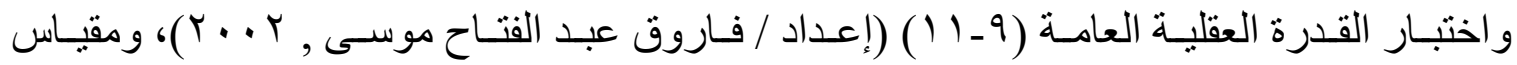

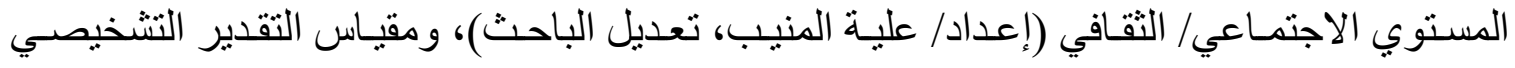

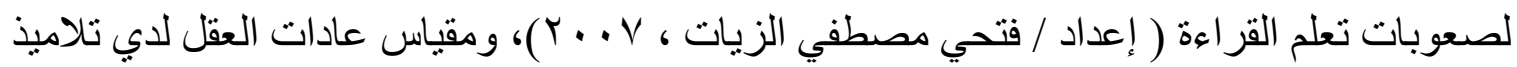

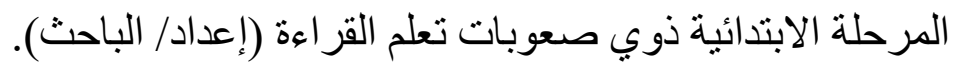

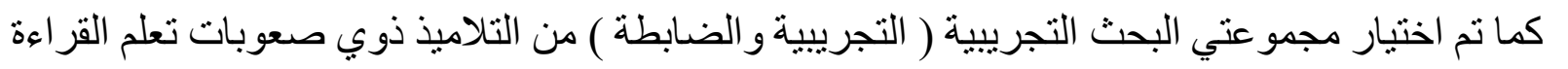

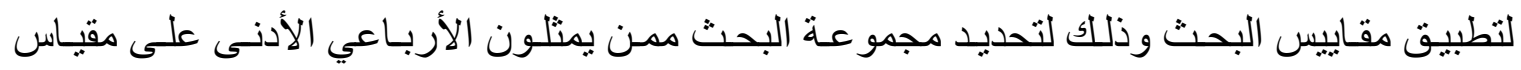
عادات العقل لدي التلاميذ ذوي صعوبات تعلم القر اءة. 


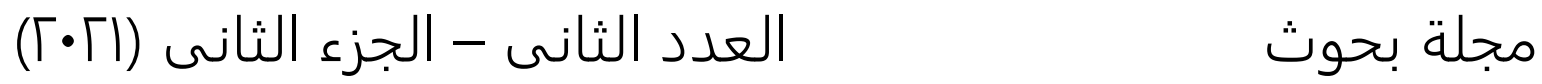 \\ "العلوم التربوية"}

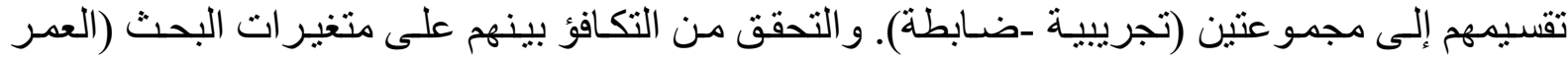
الزمني- المستوى الاجتماعي الثقافي- نسبة الذكاء- صعوبات التعلم ـ عادات العقل).

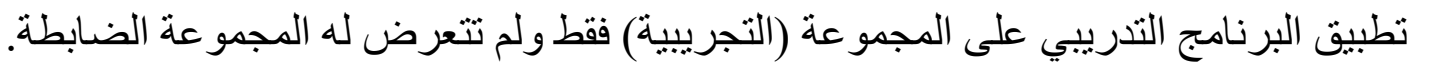
تطبيق مقياس التفاعل عادات العقل بعد انتهاء تطبيق البرنـامج التدريبي "قياس بعدي" وبعد الانتهاء بـ التباء

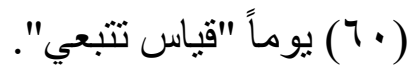

مناقثة النتائج وتفسير ها و التحقق من صحة فروض البحث. تقديم بعض التوصيات و المقترحات التربوية في ضوء ما أسفرت عنه نتائج البحث و اقتر اح بعض البحوث المستقبلية.

الأساليب الإحصائية المستخدمة

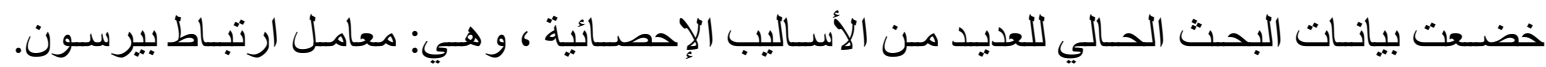

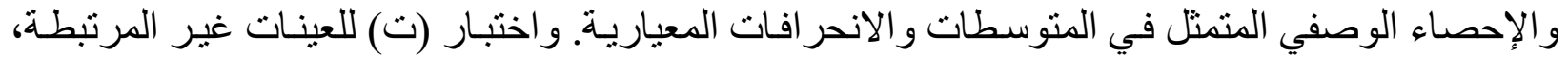
و العينات المرتبطة. وذللك من خلال برنامج (SPSS) الحقيبة الإحصائية للعلوم الاجتماعية. نتائج البحث وتفسير ها: نتائج الفرض الأول وتفسير ها:

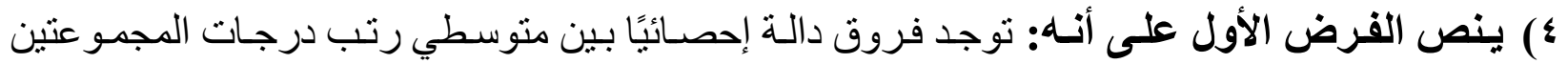
التجريبية و الضابطة في القياس البعدى لمحاور مقياس عادات العقل، ومجمو عها الكلي لصالح الصالح المجموعة التجريبية.

و لاختبار صحة هذا الفرض تم استخدام أسلوب إحصائي منمثلا في (اختبار ت t- test) للأزو اج غير المرتبطة، وذللك لحساب الفروق بين منوسطي درجات المجموعة التجريبية و المجموعة الضابطة في القياس

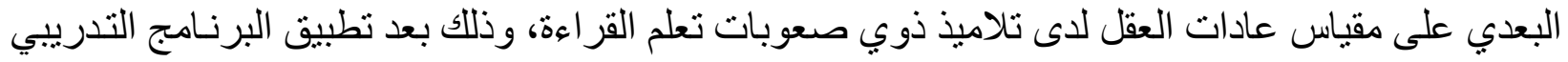

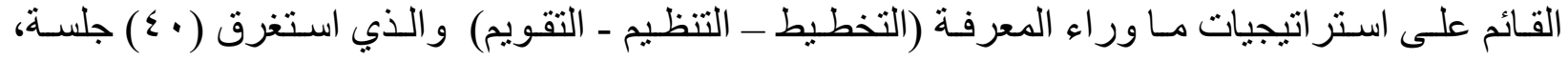

ويتضح ذللك في جدول (1) (1):

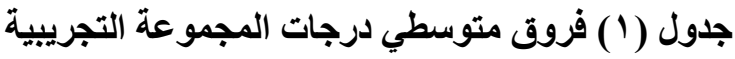

والمجموعة الضابطة في القياس البعدي لأبعاد مقياس عادات العريلة العلّ والدرجة الكلية

\begin{tabular}{|c|c|c|c|c|c|c|c|}
\hline مسلالة الدتوى & قتئ قــــة" & الحرية & المعياري_ـــــ & المتوسط & ن & المجموعة & عادات العقل \\
\hline \multirow{2}{*}{$\because \cdot 1$} & \multirow{2}{*}{$r 1 . \leqslant \leq 4$} & \multirow{2}{*}{$r \Lambda$} & Y.PTYוq & $r \leqslant .7 \ldots$ & $r$. & التجريبية & \multirow{2}{*}{ المثابرة } \\
\hline & & & 1.0141 & rT.0... & r. & الضابطة & \\
\hline \multirow{2}{*}{$\because \cdot 1$} & \multirow{2}{*}{ r..人זr } & \multirow{2}{*}{ rs } & I.T.IAY & rr.V... & $r$. & التجريبية & \multirow{2}{*}{ التحكم في التهور } \\
\hline & & & $\cdot . \wedge q \leqslant \leqslant \Gamma$ & 1 r.A... & r. & الضابطة & \\
\hline$\because \cdot 1$ & $1 V . \wedge 19$ & $r \Lambda$ & Y. $\leqslant \leqslant V Y \leqslant$ & $r 9.9 \ldots$ & $r$. & التجريبية & الإصغاء بتفهم وتعاطف \\
\hline
\end{tabular}




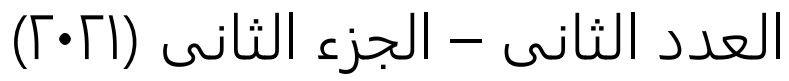
مجلة بحوث
"العلوم التربوية" مجولة "

\begin{tabular}{|c|c|c|c|c|c|c|c|}
\hline 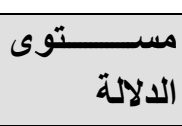 & 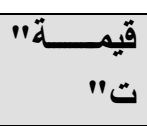 & الحرية & الالتحعياريــــراف & المتوسط & $\dot{ن}$ & المجموعة & عادات العقل \\
\hline & & & 1.17049 & $19.1 \ldots$ & r. & الضابطة & \\
\hline \multirow[b]{2}{*}{$\because \cdot 1$} & \multirow{2}{*}{$1 \wedge . \leqslant 94$} & \multirow{2}{*}{$\mu \wedge$} & Y.YฯAVA & rr.1... & $r$. & التجريبية & \multirow{2}{*}{ الكفاح من أجل الدقة } \\
\hline & & & $.99 \vee 91$ & $r r . q \ldots$ & $r$. & الضابطة & \\
\hline \multirow{2}{*}{$\because \cdot 1$} & \multirow{2}{*}{$Y \varepsilon . Y I \varepsilon$} & \multirow{2}{*}{ rᄉ } & 1.17 .97 & $r v .1 \ldots$ & $r$. & التجريبية & \multirow{2}{*}{ تطلى أوضاع المعارف الماضية } \\
\hline & & & $\because V I V V V$ & $17 . \% \ldots$ & $r$. & الضابطة & \\
\hline \multirow{2}{*}{$\because \cdot 1$} & \multirow{2}{*}{ ro. $\leqslant V}$. & \multirow{2}{*}{ rᄉ } & q.r rA.q & $1 \leqslant \Lambda . \leqslant \ldots$ & $r \cdot$ & التجريبية & \multirow{2}{*}{ العقل الدـــة الكليــة لعــادات } \\
\hline & & & $1.0 \mathrm{H} \wedge 9 \mathrm{~V}$ & $9 \leq .0 \ldots$ & $r$. & الضابطة & \\
\hline
\end{tabular}

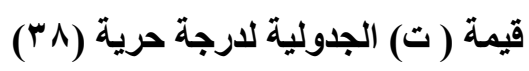

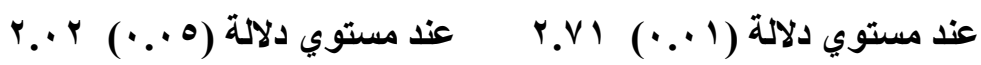

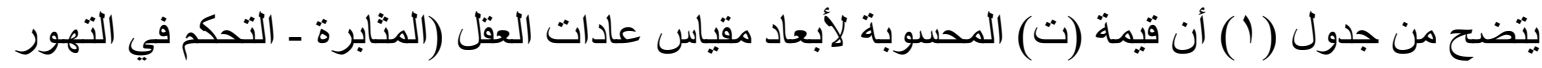

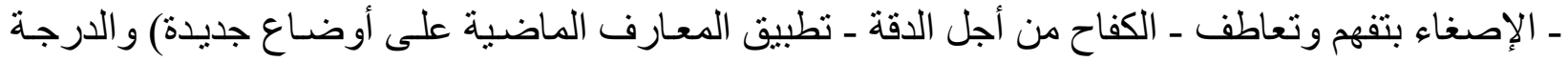

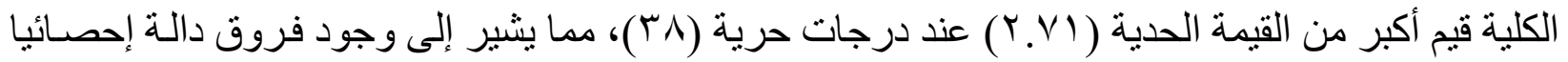

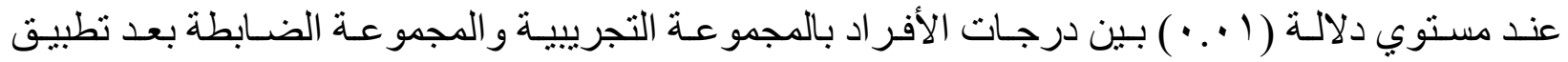

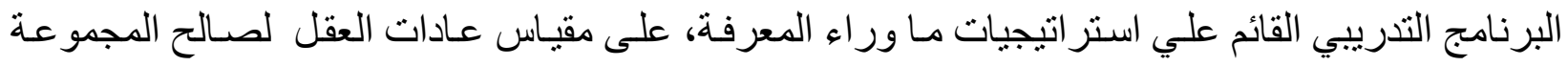

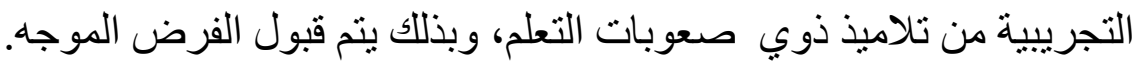

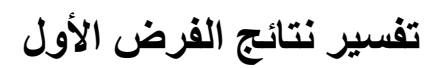

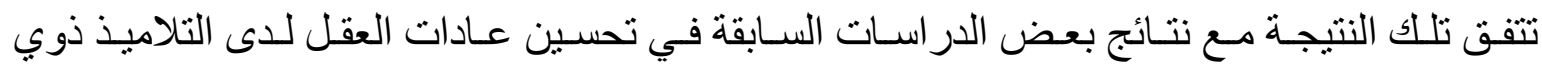

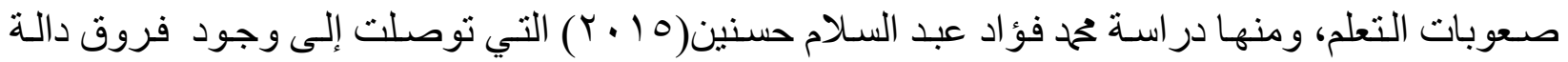

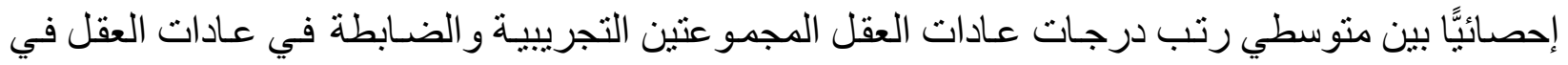

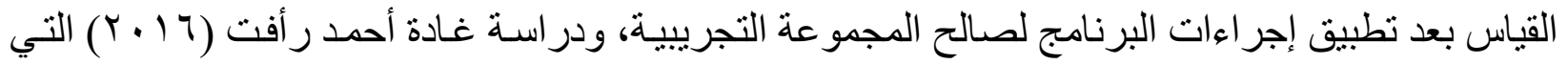

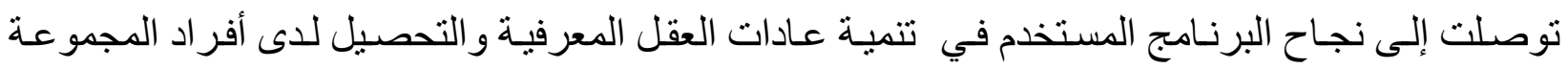

التجريبية التي طبق عليها البرنامج دون المجموعة الضابطة وكان التحسن لصالح المجموعة التجريبية. ويرجع هذا إلى البرنامج التدريبي القائم علي استر اتيجيات مـا ور اء المعرفة التي طبق على تلى تلاميذ

المجموعة التجريبية لتحسين عادات العقل : التربئ

أو لا المثابرة: وتعني الإصر ار و العزيمة على مو اصلة بذل الجهود في التعلم من خلال انشطة البرنامج.

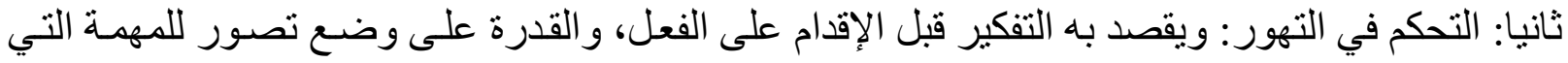
سيقوم المتعلم بدر استها، ويعرف بأنه التأني و التفكير بتروي والإمالت التحكم بالتهور عند حل المشكلات. ثالثا: الإصغاء بتفهم وتعاطف: إن الإصغاء هو بدايـة الفهم و الحكمة، و القدرة على إعـادة صياغة مفاهيم ومشكلات و عو اطف و أفكار الآخرين بشفافية وإضافة معان لتوضيحها وتقديم أمنلة عليها. 


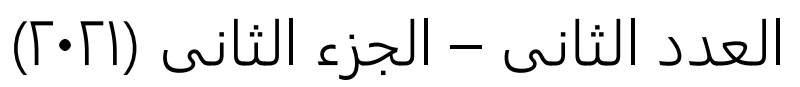
مجلة بحوث

"العلوم التربوية بحوثة"

رابعا: الكفاح من أجل الدقة: القدرة على العمل من اجل الكمـال و العمل المتو اصل بحرفية و إتقان وتفحص

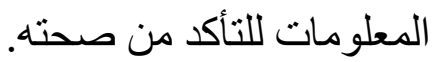

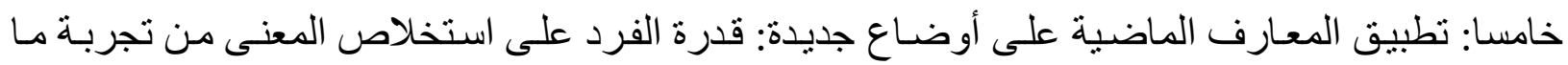

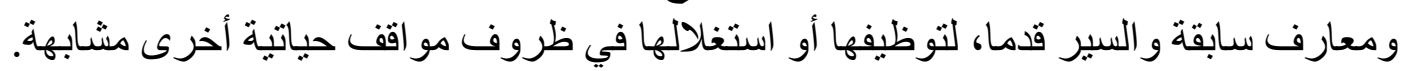

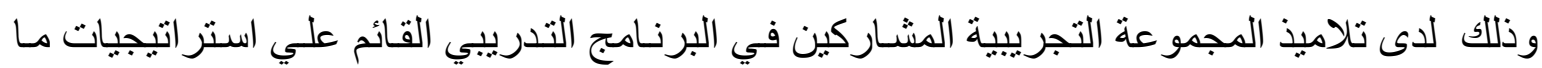

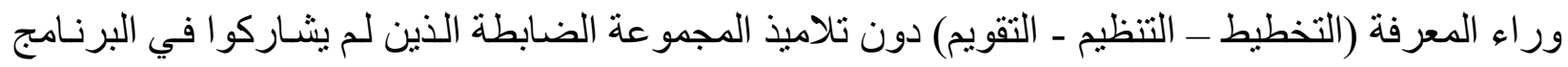

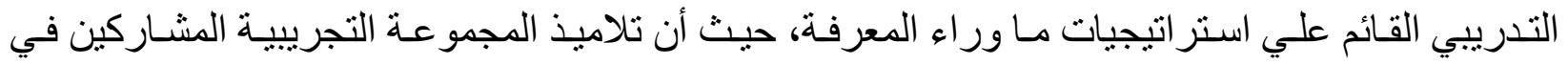

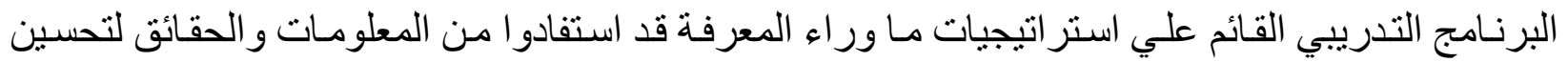

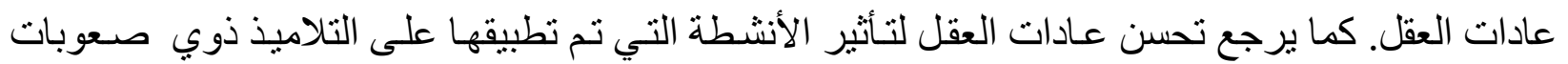

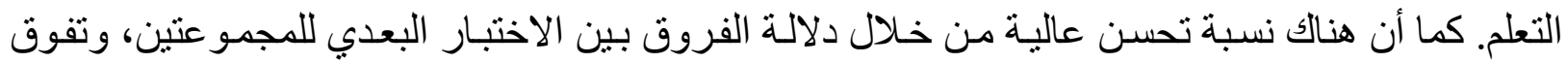

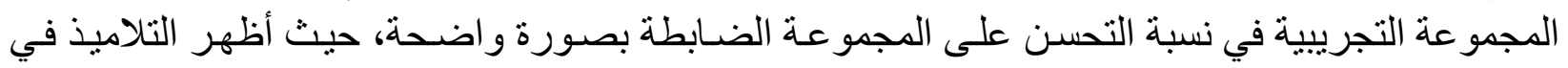

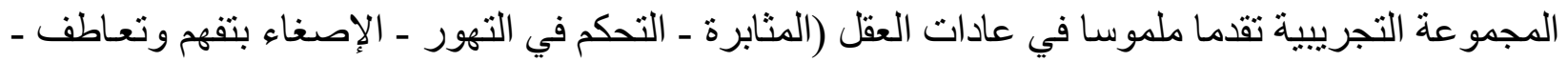

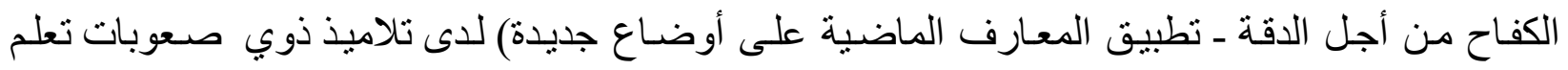
القر اءة.

ونظر أ لأهمية ما ور اء المعرفة فقد عمل بعض الباحثين على تنمية مهار ات ما وراء المعرفة من خلال

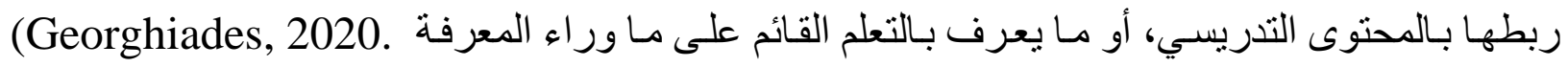

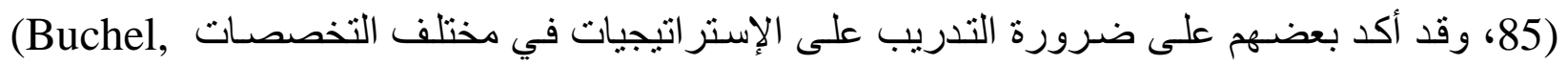

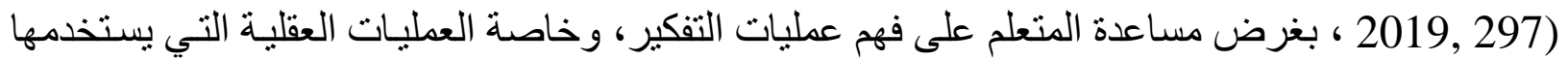

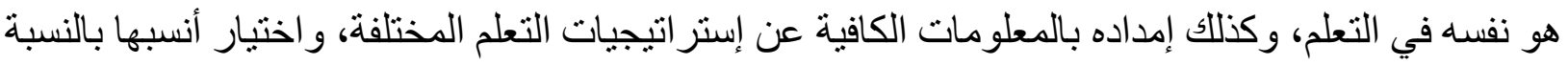

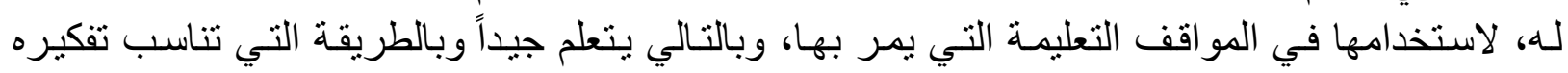

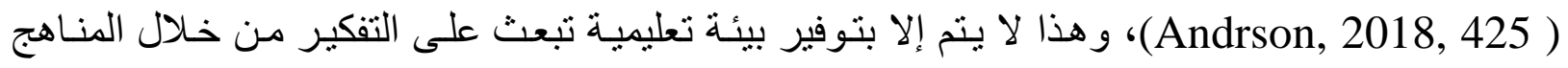

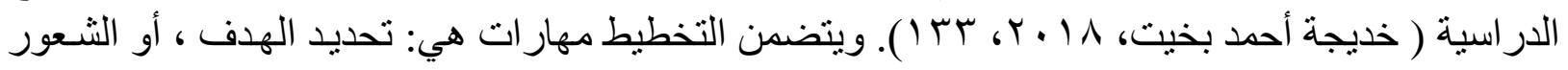

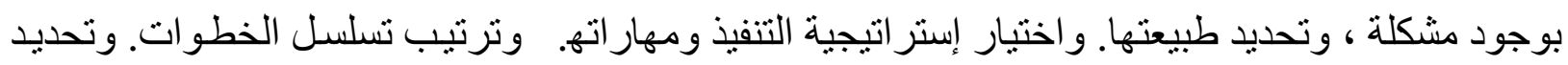

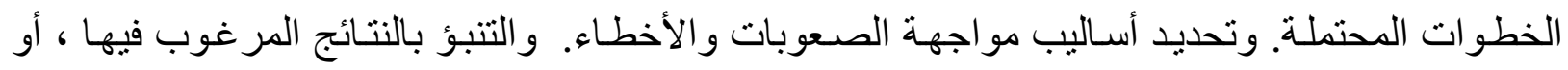

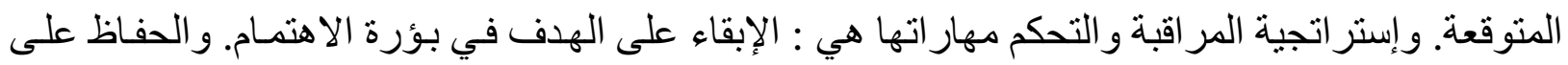

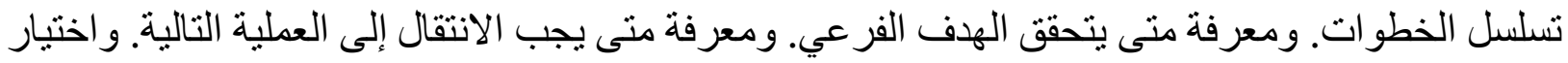

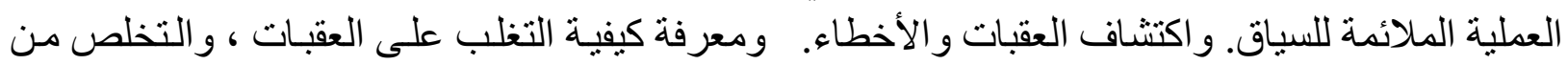

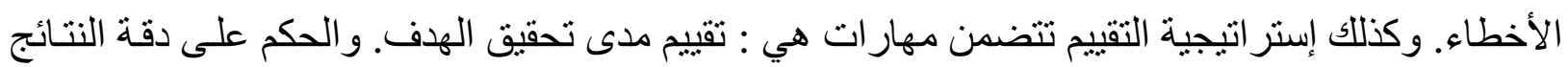

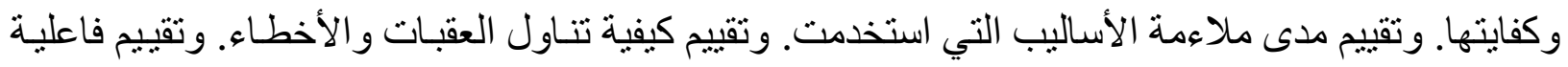
الخطة وتنفيذها. 


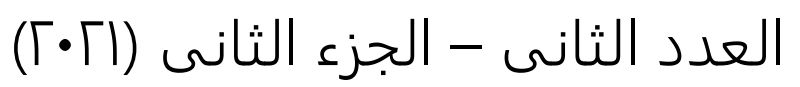

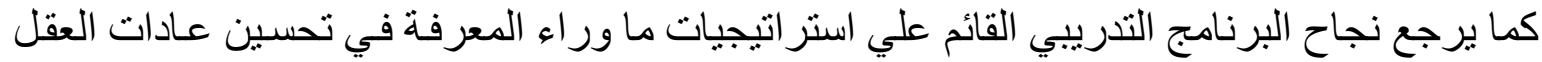

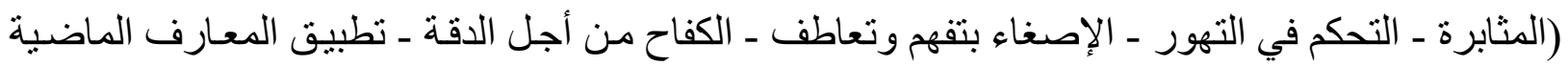

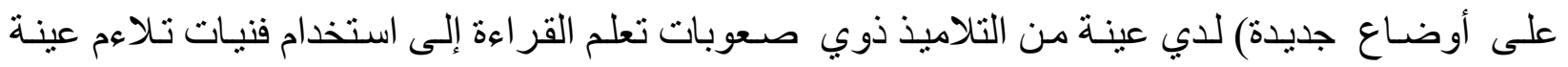

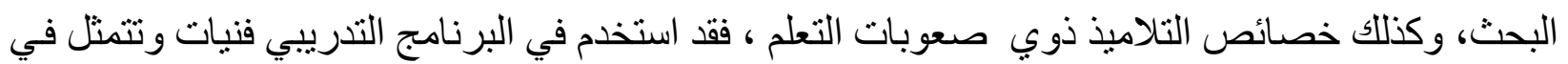
المحاضرة والمناقتة الجماعية، النمذجة، انتقال أثر التذريب، العصف التصفي الذهني، التغذية الراجعة.

توفير الفرص الكافية للتناميذ للتمرين على علاج أخطاء الكتابة، وإيضاح التناميذ تفكير هم للآخرين،

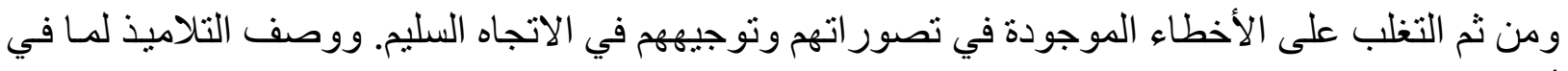

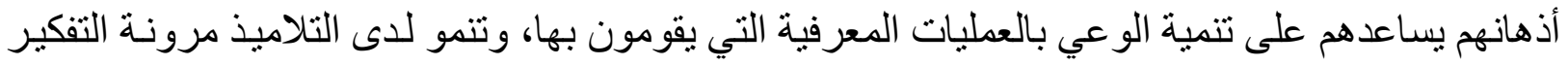

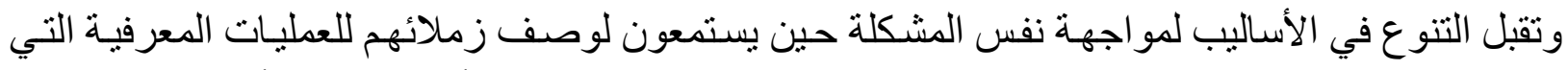

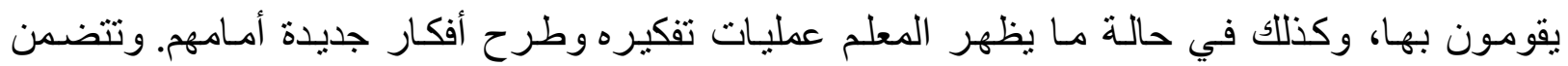

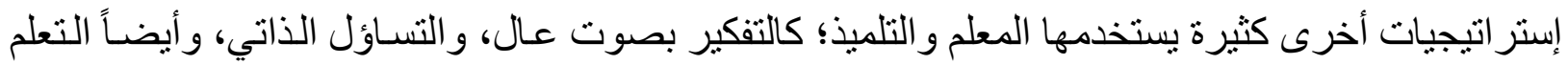

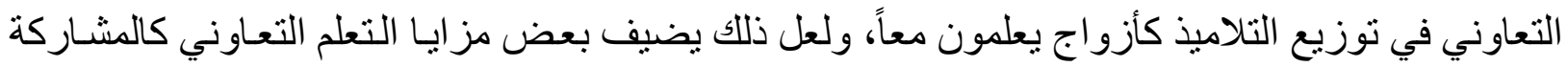

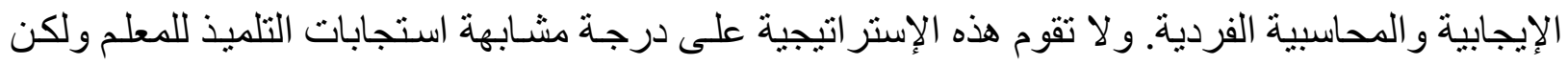
تسمح باختلاف رؤى وطرق حلول التلميذ عن المعلم.

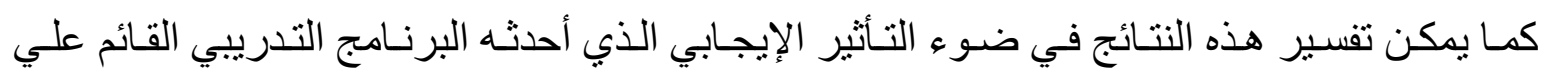

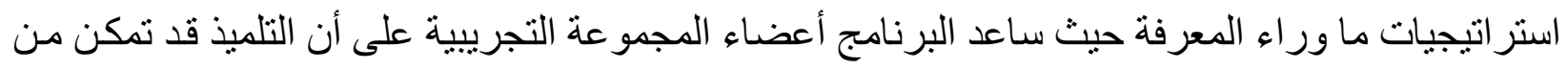

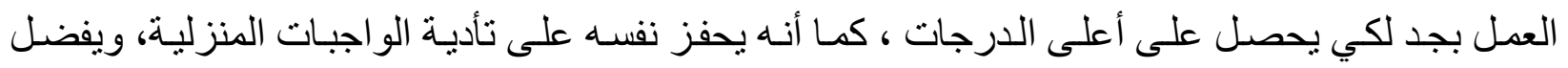

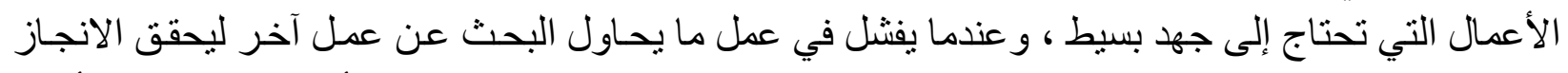

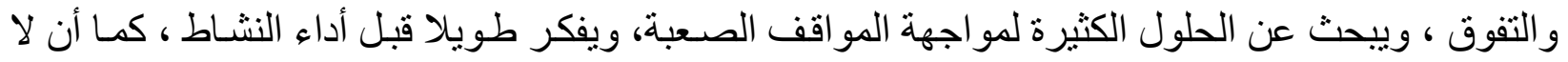

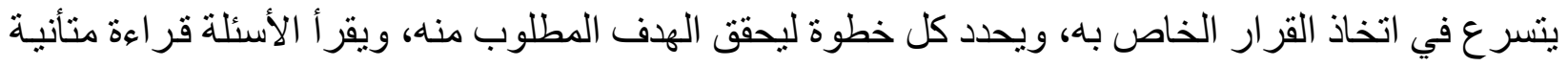

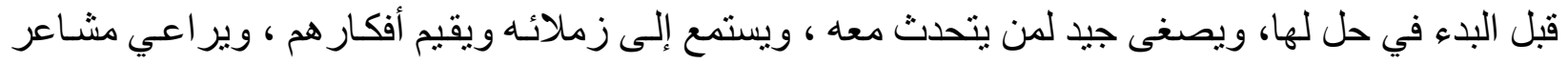

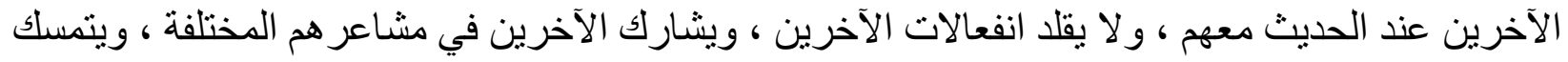

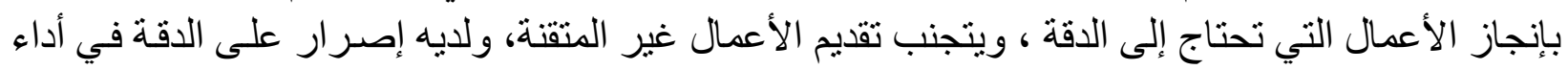

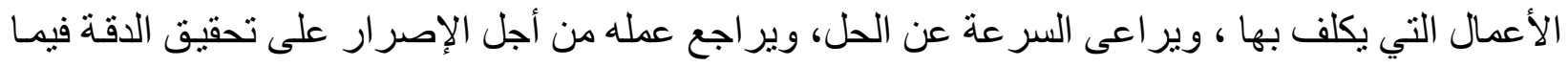

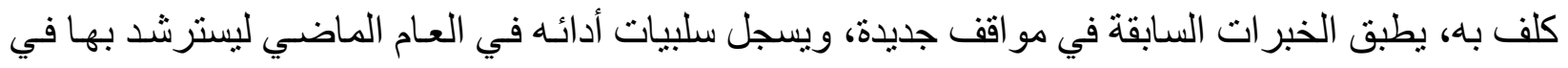

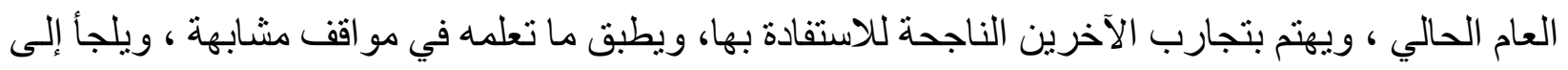
الأمثلة المحلولة لحل المسألة الحالية.

فقد أظهرت نتائج البحث تحقق الفرض في تحسين عادات العقل لدى تلاميذ المرحلة الابتدائية ذوي صعوبات تعلم القراءة. 


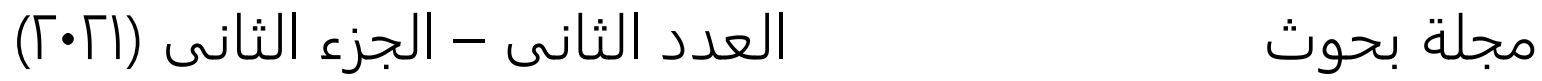 \\ "العلوم التربوية"}

\section{نتائج الفرض الثاني وتفسيرها:}

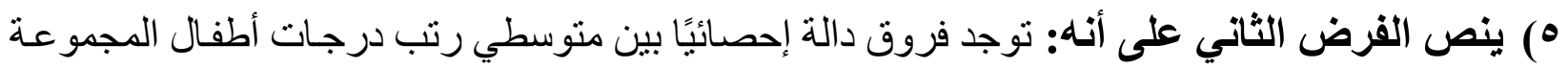

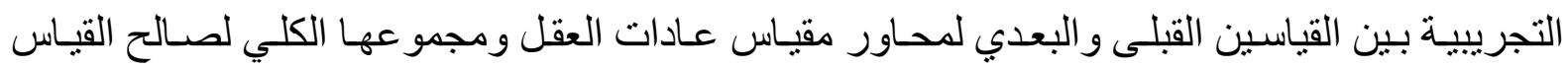

$$
\text { البعدي. }
$$

و لاختبار صحة هذا الفرض تم استخدام أسلوب إحصائي متمثلا في (اختبار ت t- test ) للأزواج

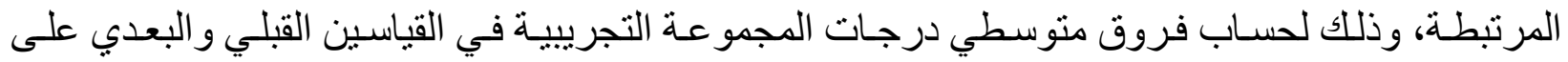

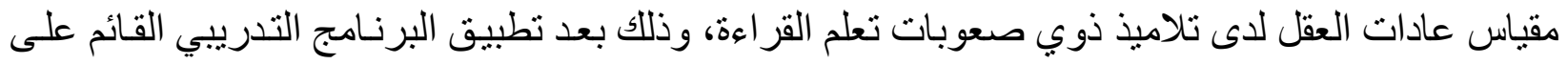

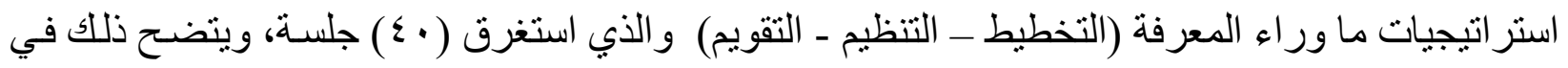

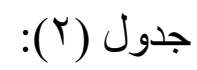

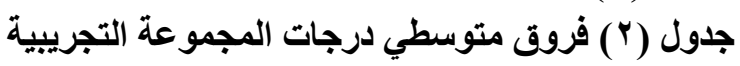
في القياسين القبلي و البعدي لأبعاد مقياس عاد البموات العقل و والدرجة الكلية

\begin{tabular}{|c|c|c|c|c|c|c|c|}
\hline مستوى الدلالة & قتيمـــــة" & داجرية & 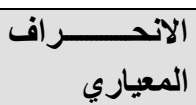 & المتوسط & ن & القياس & عادات العقل \\
\hline \multirow{2}{*}{$\because \cdot 1$} & \multirow{2}{*}{$r \leq .91 Y$} & \multirow{2}{*}{19} & $1 . \wedge 91 \wedge 1$ & $r \leq . .$. & $r$. & القبلي & \multirow{2}{*}{ المثابرة } \\
\hline & & & Y.9Y19 & $r \varepsilon .7 \ldots$ & $r$. & البعدي & \\
\hline \multirow{2}{*}{$\because+1$} & \multirow{2}{*}{ ro.sı } & \multirow{2}{*}{19} & I.YOYTV & 1 1 .9... & $r$. & القبلي & \multirow{2}{*}{ التحكم في التهور } \\
\hline & & & $1 . r \cdot 1 \wedge r$ & rr.v... & $r$. & البعدي & \\
\hline \multirow{2}{*}{$\because+1$} & \multirow{2}{*}{19.500} & \multirow{2}{*}{19} & $\cdot .9 \varepsilon \cdot M r$ & $11.7 \ldots$ & $r$. & القبلي & \multirow{2}{*}{ الإصغاء بتقهم وتعاطف } \\
\hline & & & $Y . \varepsilon \varepsilon V Y \varepsilon$ & rq.9... & r. & البعدي & \\
\hline \multirow{2}{*}{$\because+1$} & \multirow{2}{*}{ ro.107 } & \multirow{2}{*}{19} & $1 . r 90 \leqslant 1$ & r1.0... & $r$. & القبلي & \multirow{2}{*}{ الكفاح من أجل الدقة } \\
\hline & & & 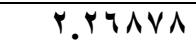 & rr.1... & $r$ r. & البعدي & \\
\hline \multirow{2}{*}{$\because+1$} & \multirow{2}{*}{ קT.r. } & \multirow{2}{*}{19} & $1 . \cdot r \Delta q 1$ & $17 . \ldots$ & $r$. & القبلي & \multirow{2}{*}{ تطبيق أوضعارع جديدة الماضية } \\
\hline & & & 1.19 .97 & $r v .1 \ldots$ & $r$. & 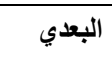 & \\
\hline \multirow{2}{*}{$\because \cdot 1$} & \multirow{2}{*}{$r \cdot r V_{1}$} & \multirow{2}{*}{19} & $r . \leq 9 \leq r 4$ & $94 . . .$. & r. & القبلي & \multirow{2}{*}{ العقل جــة الكليــة لعــادات } \\
\hline & & & $9 . r+\wedge .9$ & $1 \leqslant \Lambda . \leqslant \ldots$ & $r$. & البعدي & \\
\hline
\end{tabular}

قيمة (ت) الجدولية لارجة حرية (9 (19)

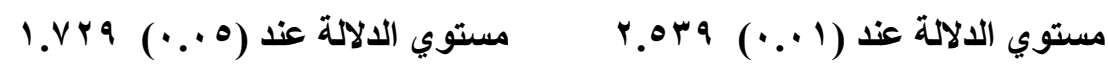

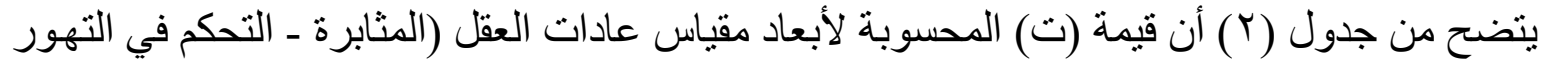

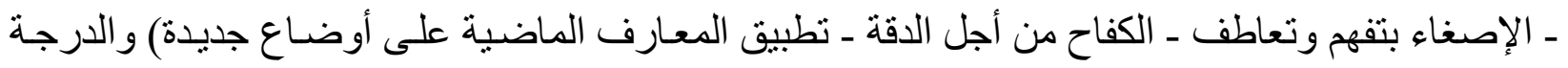

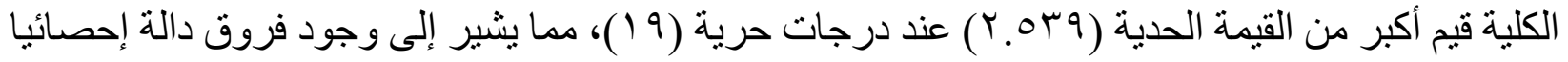

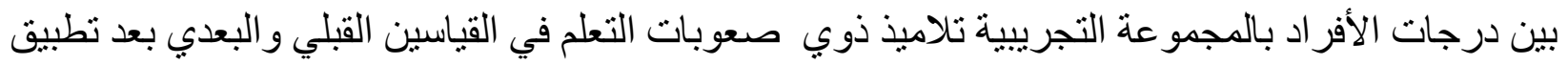

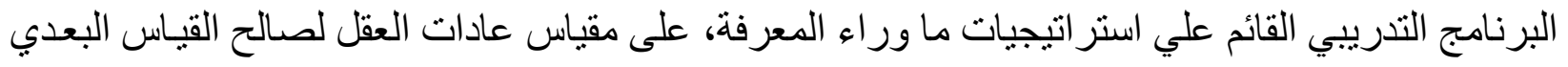
، وبذلك ينم قبول الفرض الموجها. 


\section{تفسير نتائج الفرض الثاني}

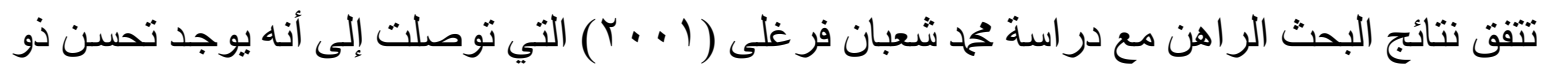

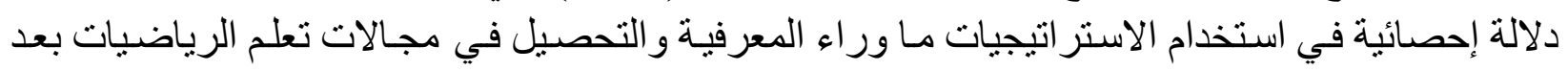

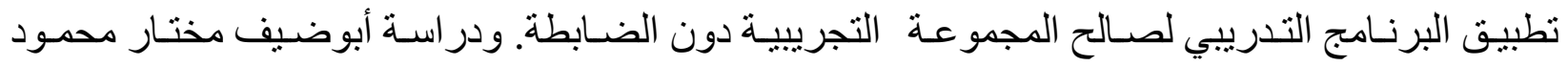

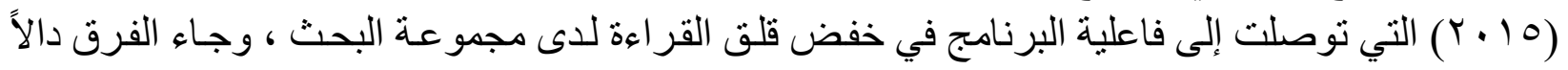

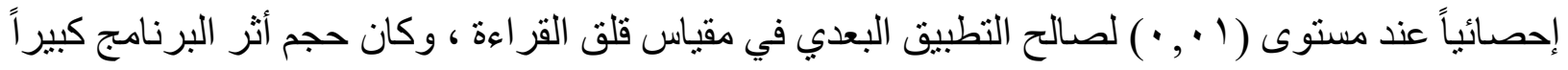

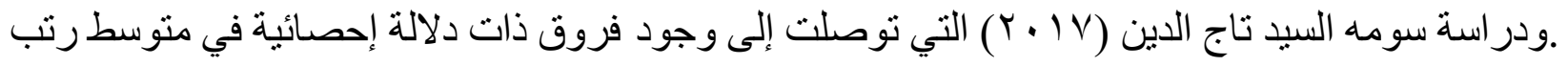

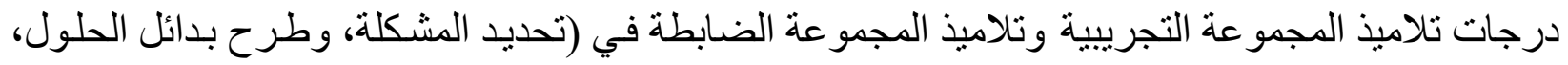

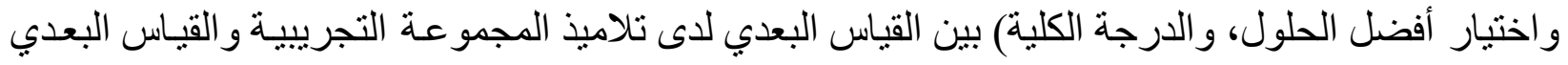

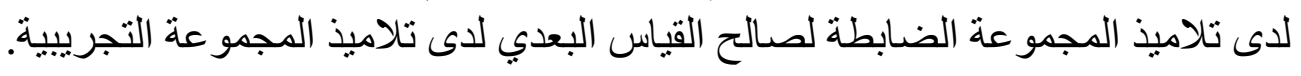

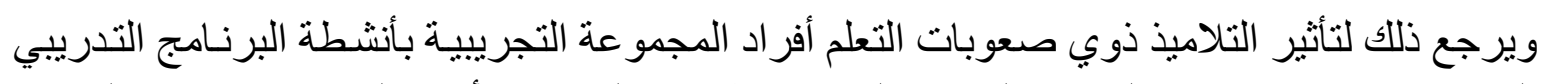

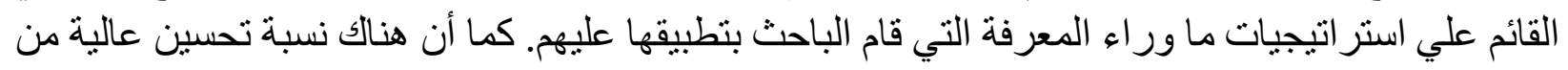

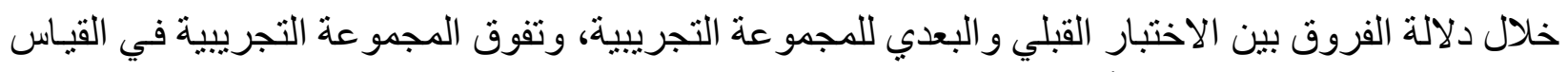

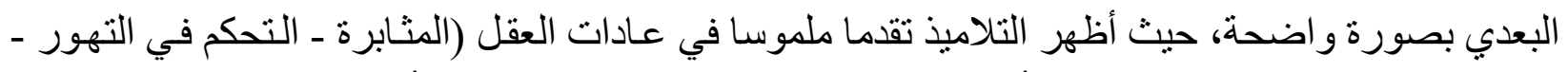

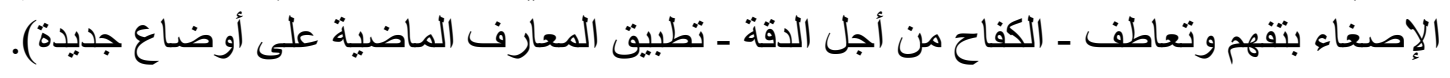

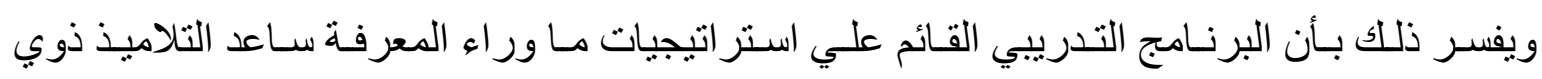

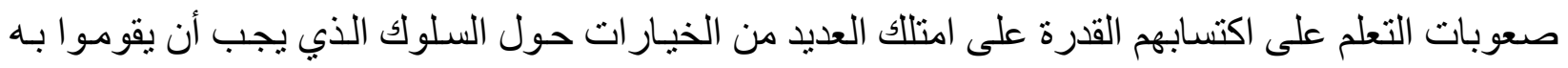

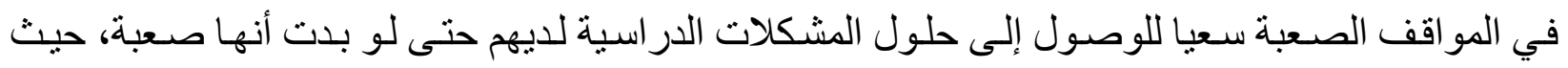

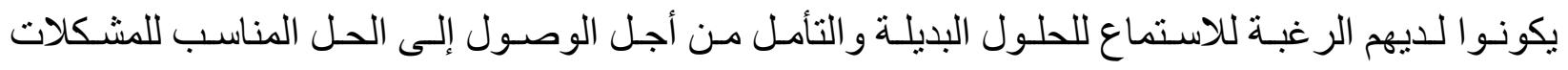

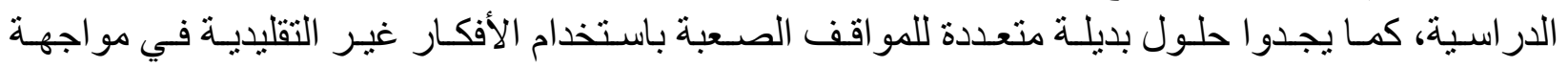

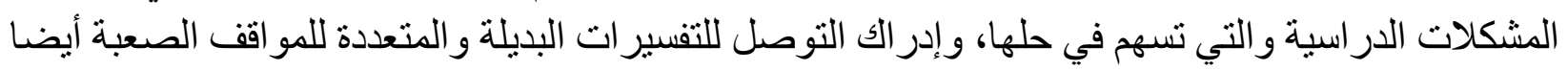
بالتذكر للمعارف في المواقف الصعبة؛ التي تؤدي بدور ها إلي ثقة التلاميذ بأنفسهم، وتحسين عادات التهات العقل.

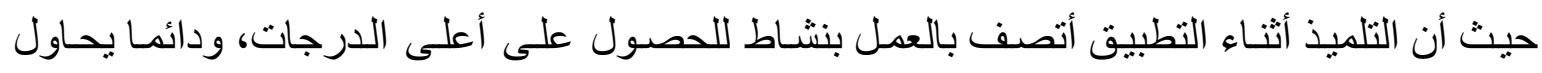

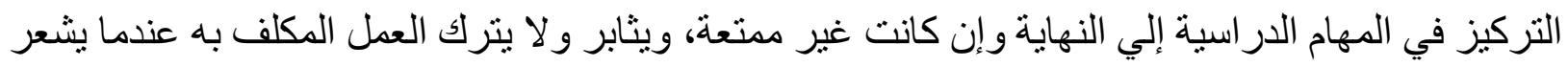

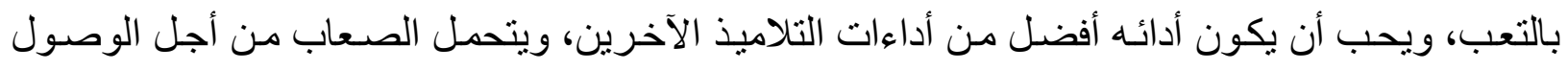

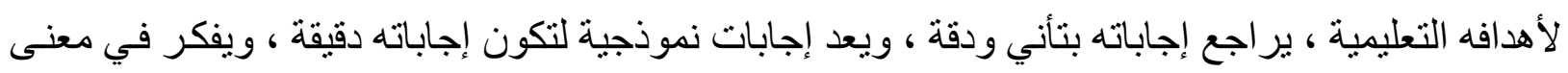

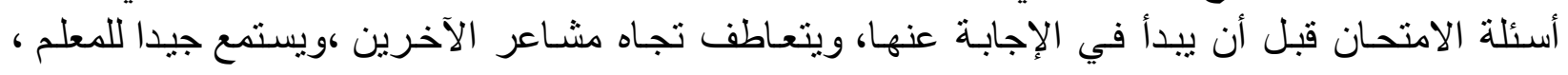

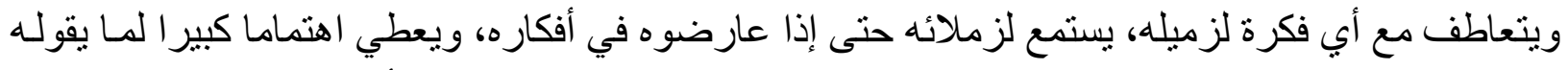

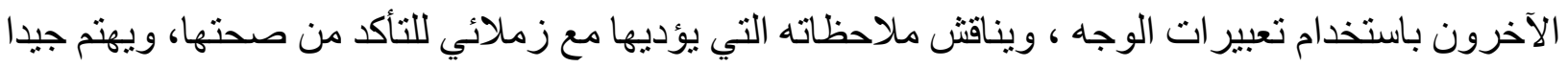

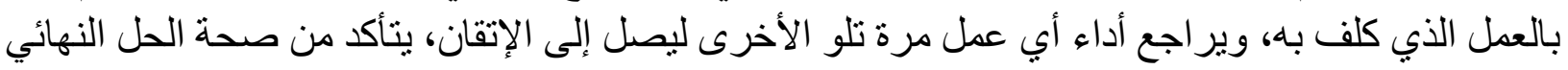

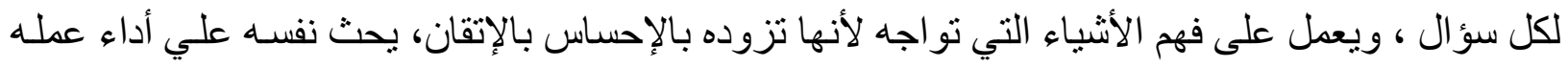




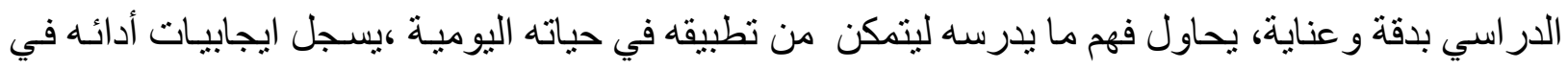
العام الماضي ليسترشد بها في العام الحالي،يربط بين لئن الأفكار المختلفة فيما يدرسه.

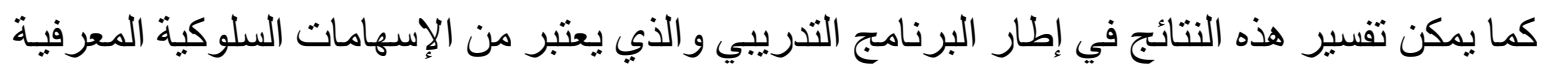

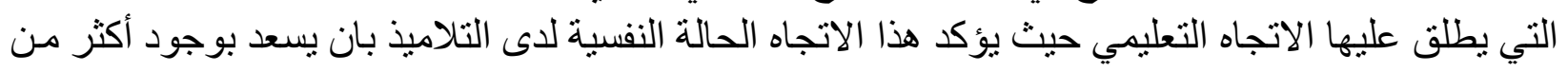

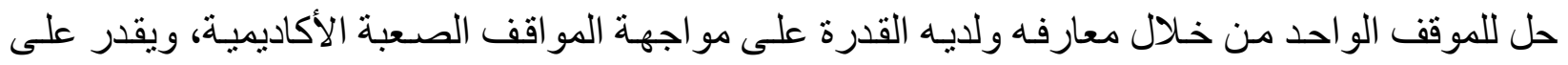

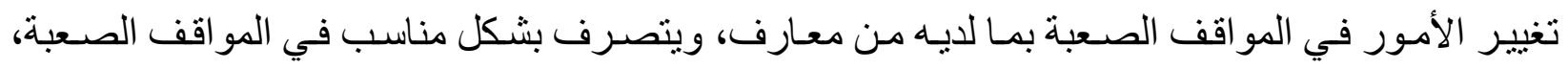

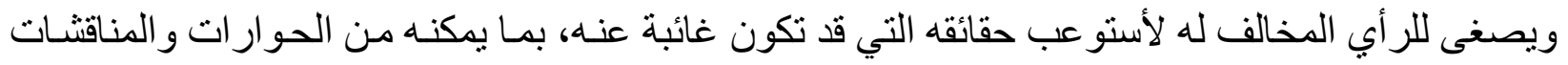

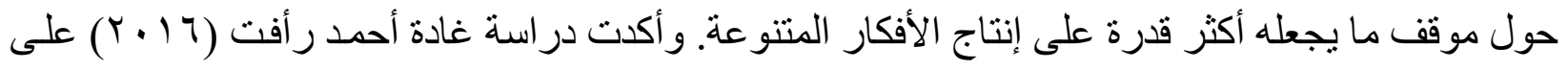

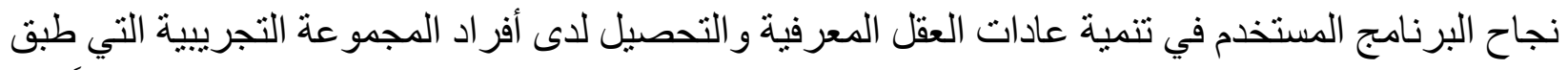

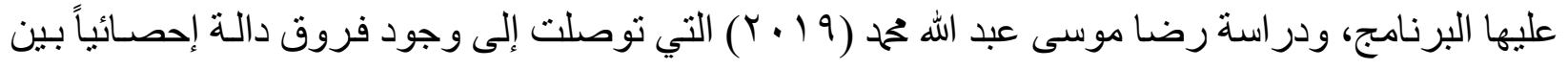

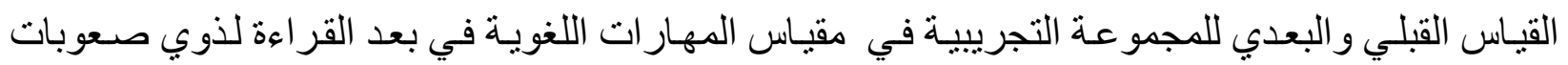

كما تفسر النتائج التي تم التوصل إليها من خلال تنوع الأساليب التي اتبعت في البرنامج التدريبي القائم

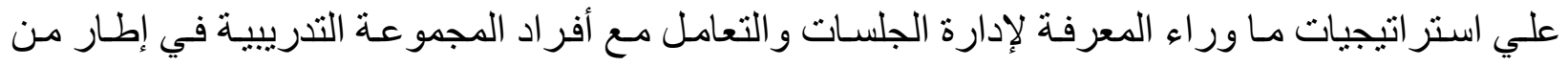

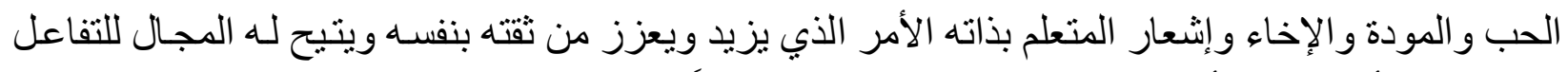

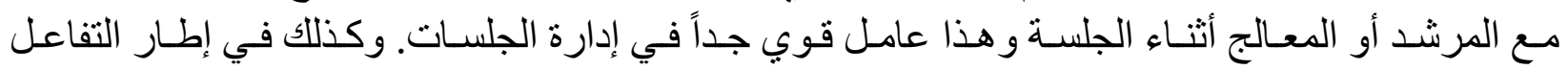

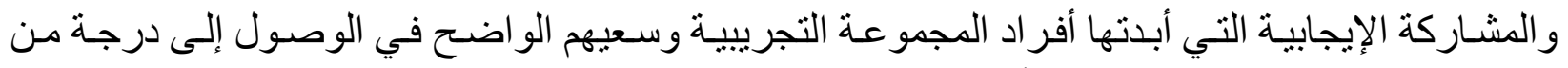

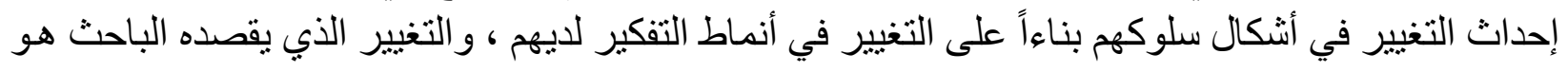

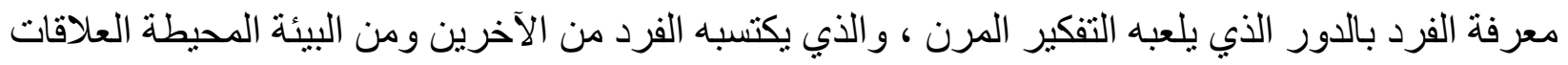

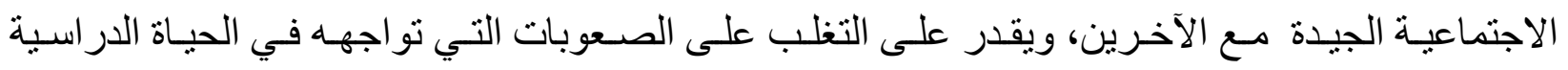

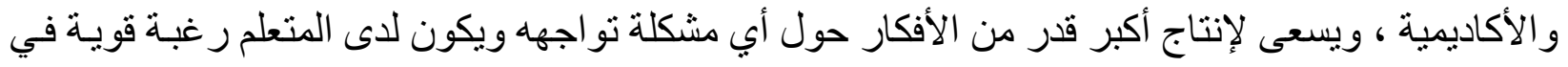

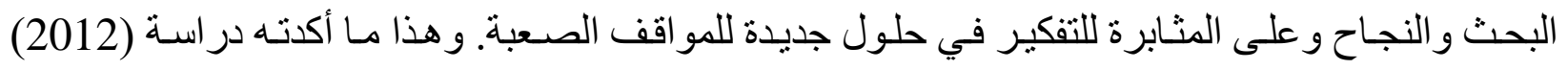
Culler

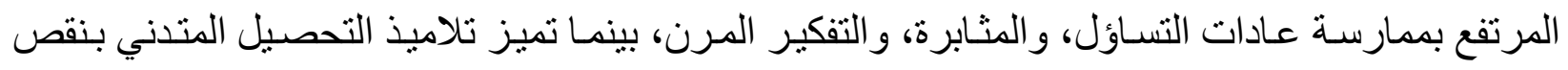

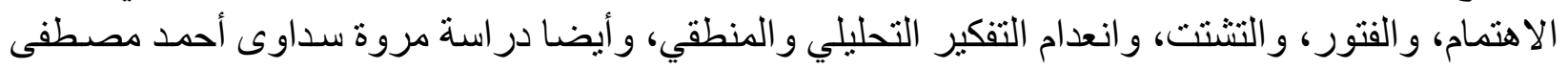

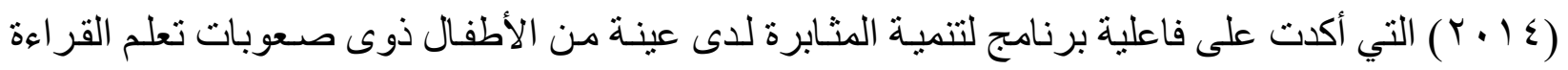

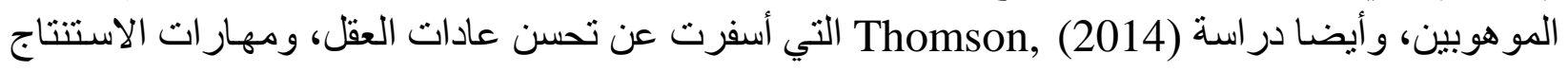
و التفكير، وضرورة واضئ تنمية عادات العقل في المرحلة الابتدائية.

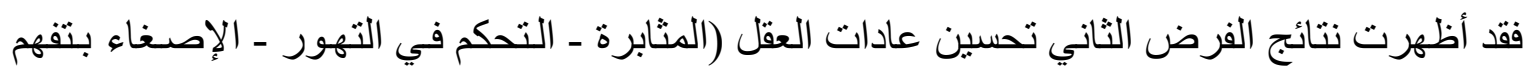

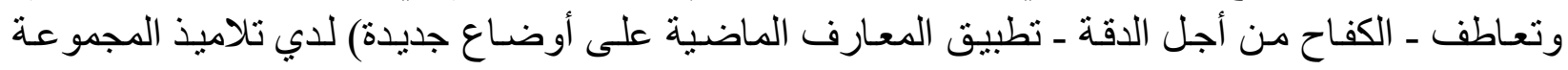

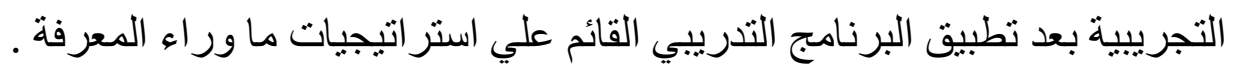




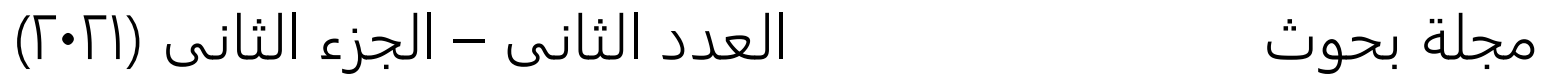 \\ "العلوم التربوية بهوبة"}

نتائج الفرض الثالث وتفسير ها:

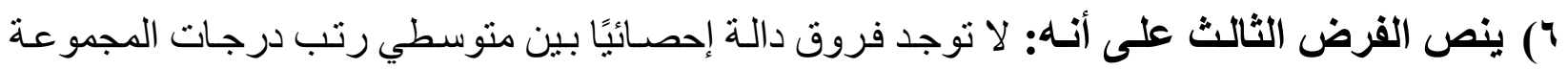

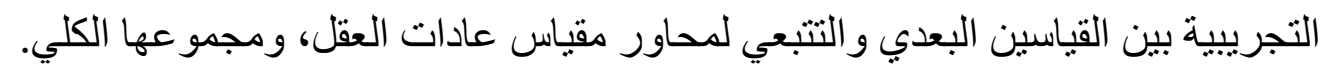

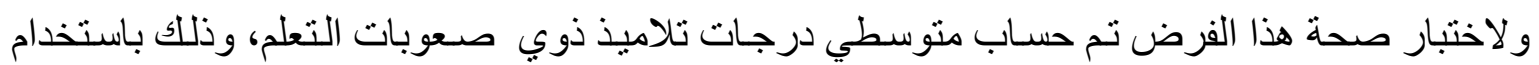

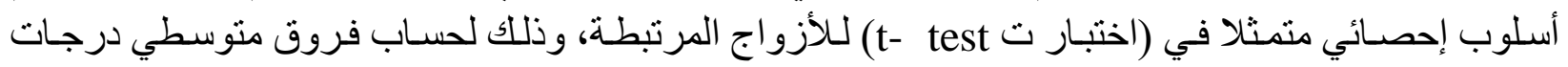

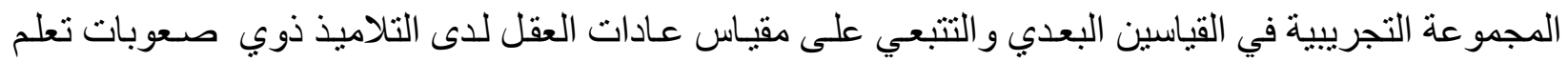

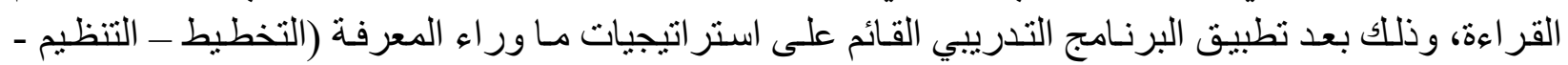

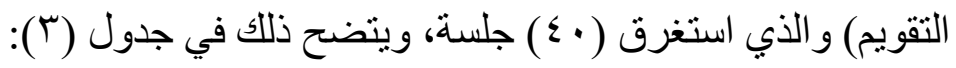

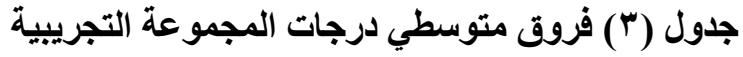
في القياسين البعدي والتتبعي لأبعاد مقياس عادات الجيوعة العقل والدرجة الكلية

\begin{tabular}{|c|c|c|c|c|c|c|c|}
\hline مستوى الدلالة & قتئ قــــة" & الحرية & الالاحعياري_ـــــ & المتوسط & ن & القياس & عادات العقلّ \\
\hline \multirow[t]{2}{*}{ غير دالة } & \multirow{2}{*}{ •. } & \multirow{2}{*}{19} & $r . .4 r 19$ & $r \leqslant .7 \ldots$ & r. & 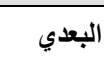 & \multirow{2}{*}{ المثابرة } \\
\hline & & & $1.990 \leq 0$ & $r \leqslant . \ldots$ & r. & التتبعي & \\
\hline \multirow[t]{2}{*}{ غير دالة الة } & \multirow{2}{*}{$\cdot . \mathrm{TIV}$} & \multirow{2}{*}{19} & $1 . r \cdot 1 A r$ & rT.V... & $r$. & البعدي - ل البعي & \multirow{2}{*}{ التحكم في التهور } \\
\hline & & & . VTVVV & rr.A... & r. & التتبعي & \\
\hline \multirow[t]{2}{*}{ 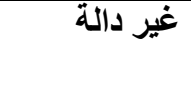 } & \multirow{2}{*}{$\cdot . \wedge \cdot 9$} & \multirow{2}{*}{19} & $Y . \leqslant \leqslant V T \leqslant$ & $r 9.9 \ldots$ & r. & البعدي & \multirow{2}{*}{ الإصغاء بتفهم وتعاطف } \\
\hline & & & 1.57049 & r9.7... & r. & التتبعي & \\
\hline \multirow[t]{2}{*}{ 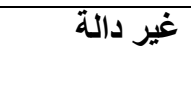 } & \multirow{2}{*}{$.00 Y$} & \multirow{2}{*}{19} & r.rYAVA & rr.1... & r. & 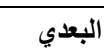 & \multirow{2}{*}{ الكفاح من أجل الدقة } \\
\hline & & & . VTVVV & rr.A... & $r$. & 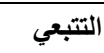 & \\
\hline \multirow[t]{2}{*}{ غير دالة الة } & \multirow{2}{*}{$.01 \leqslant$} & \multirow{2}{*}{19} & 1.17 .97 & rV.I... & $r$. & البعدي - ل البعي & \multirow{2}{*}{ تطبيق المعارف الماضية } \\
\hline & & & $\cdot . \wedge \vee 0.9$ & 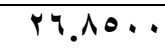 & $r$. & التتبعي التئي & \\
\hline \multirow{2}{*}{ 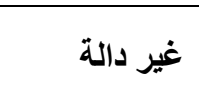 } & \multirow{2}{*}{$\therefore \leqslant 9 \vee$} & \multirow{2}{*}{19} & $9.4 r A .9$ & $1 \leqslant \wedge . \leqslant \ldots$ & r. & 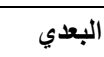 & \multirow{2}{*}{ العقل جــة الكليـة لعـادات } \\
\hline & & & $r . r \cdot 0 \cdot r$ & $1 \leqslant V . \leqslant 0 \ldots$ & r. & التتبعي & \\
\hline
\end{tabular}

قيمة (ت) الجدولية لارجة حرية (9 (19)

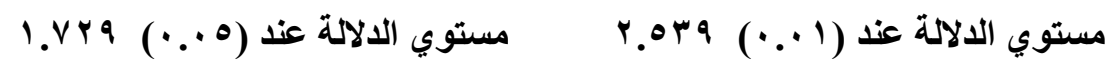

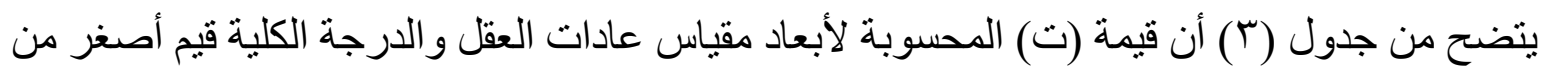

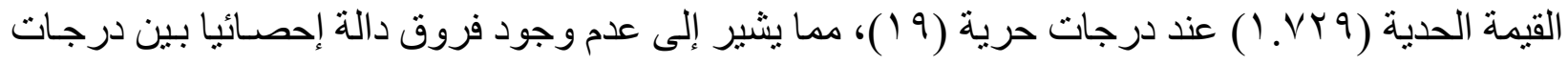

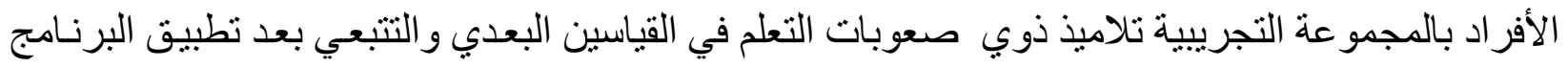

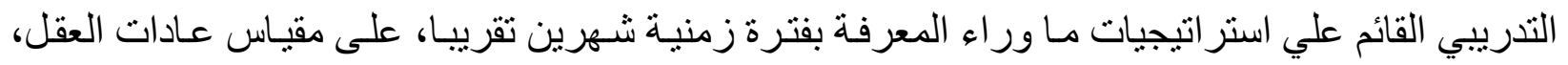
وبذللك يتم قبول الفرض الموجه. 


\section{تفسير نتائج الفرض الثالث}

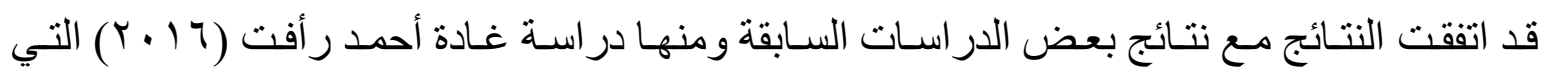

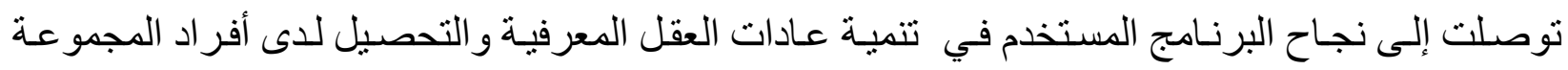
التجريبية التي طبق عليها البرنامج، مع استمر ار التأثيرات الإيجابية للبرنامج خلات العلال الفترة التتبعية.

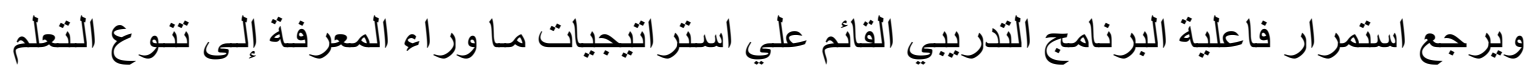

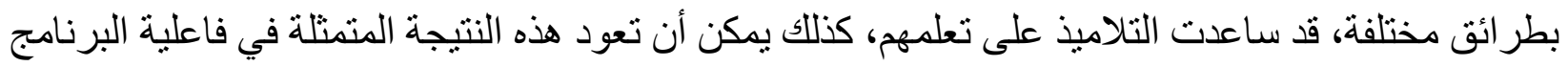

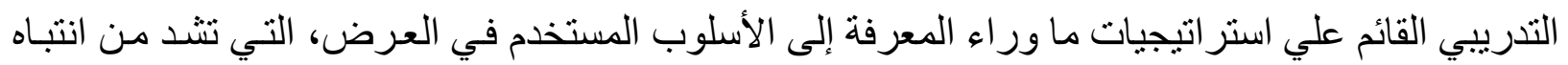

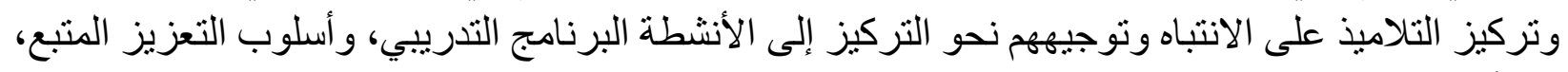

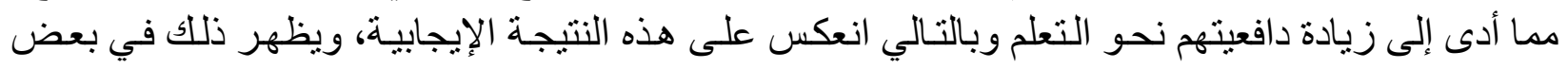

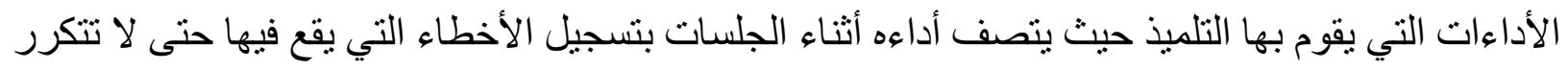

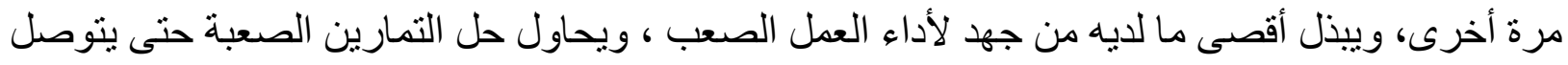

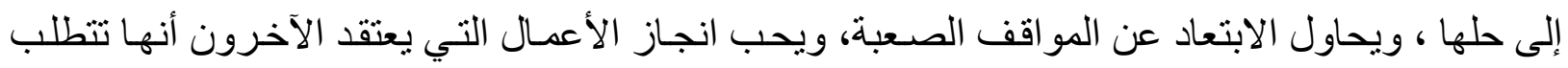

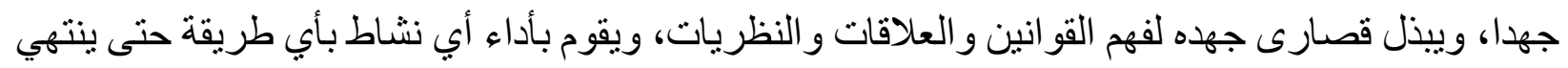

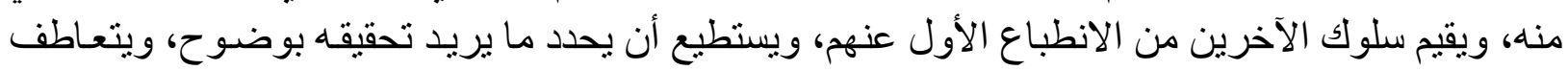

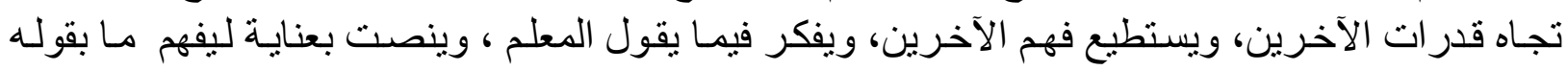

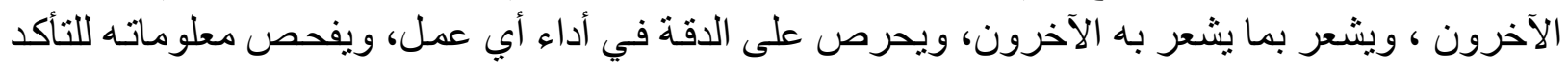

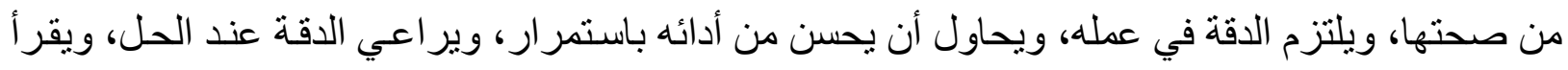

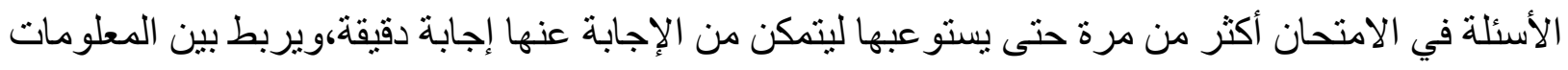

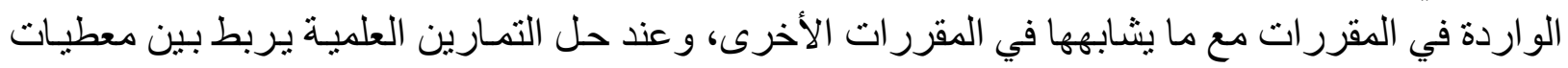

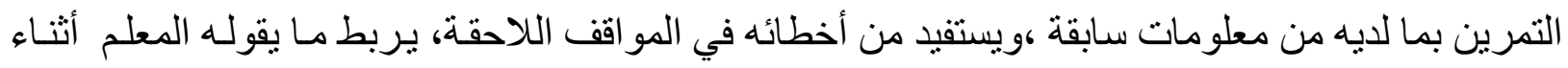

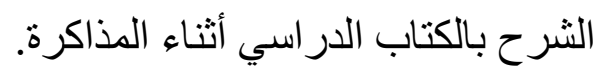

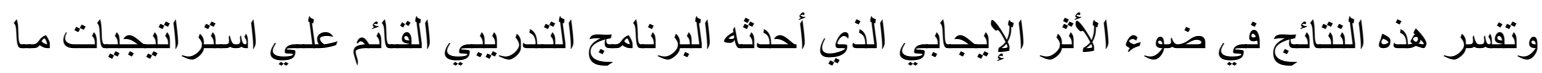

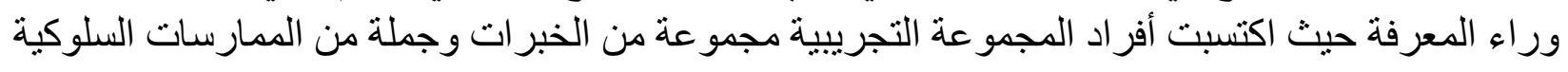

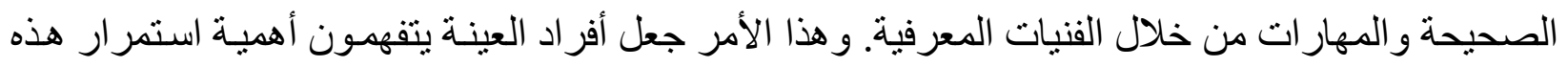

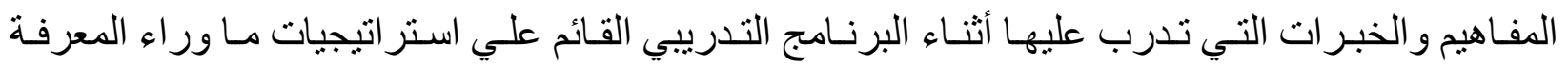

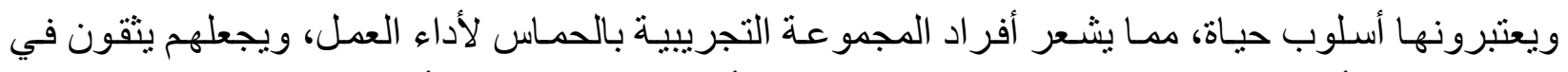

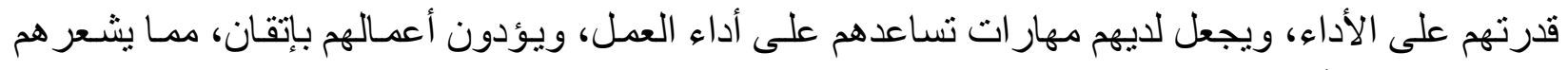

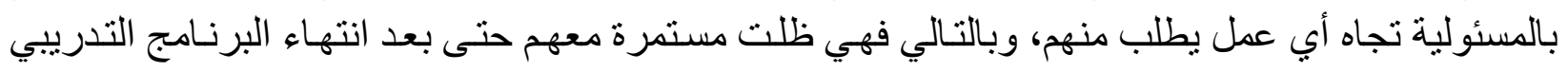

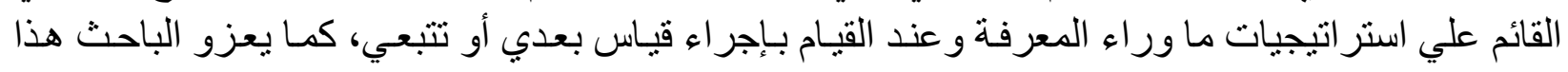

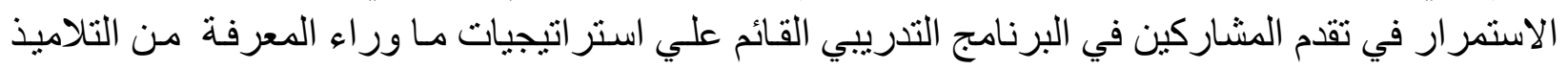

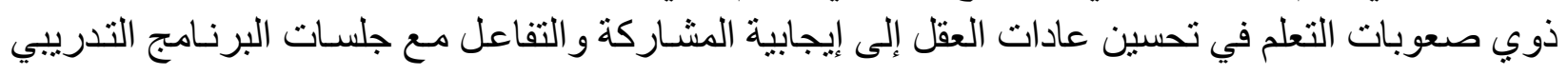




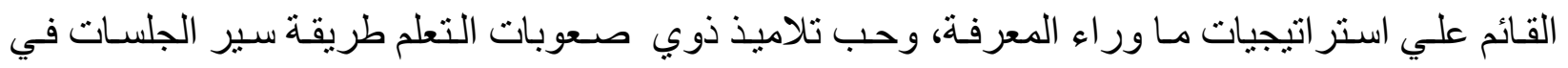

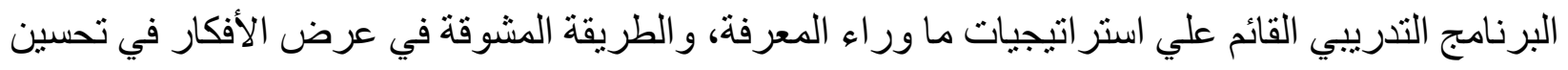

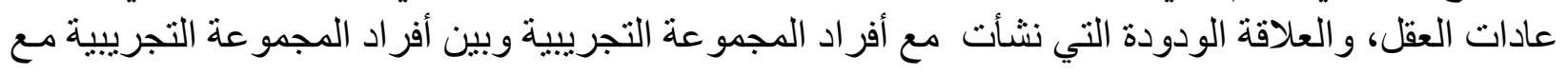
بعضهم البعض.

فقد أكدت نتائج الفرض الثالث على عدم وجود فروق ذات دلالة إحصائية بين منوسطي درجات عادات

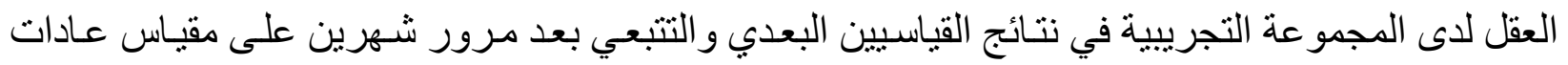

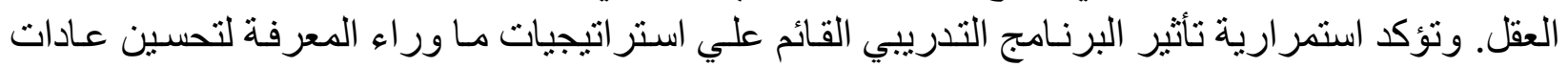

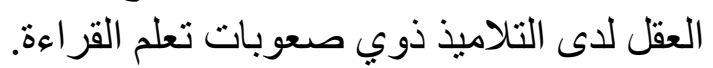

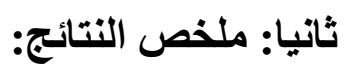

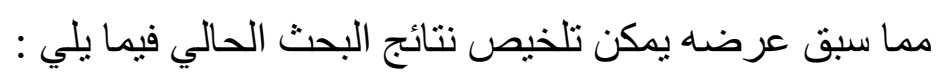

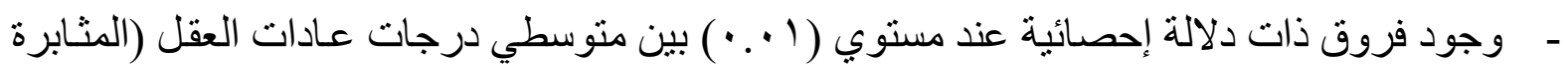

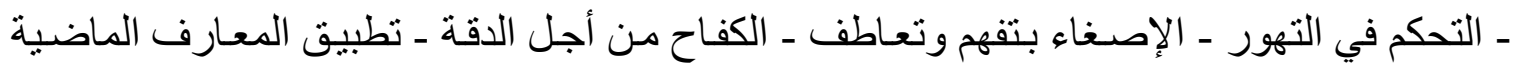

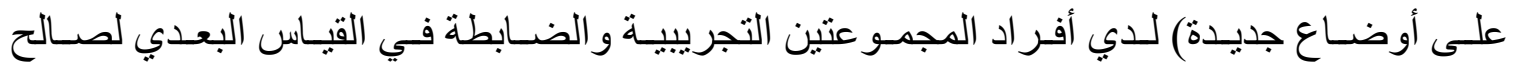

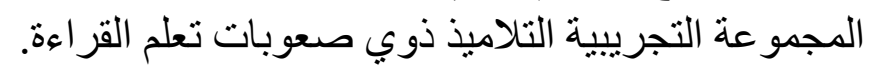

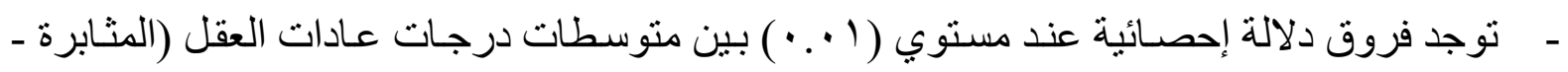

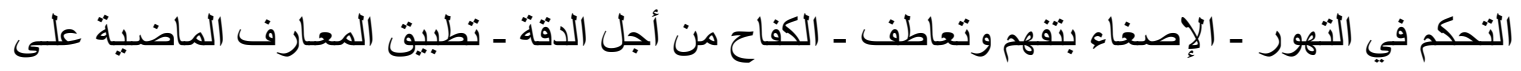

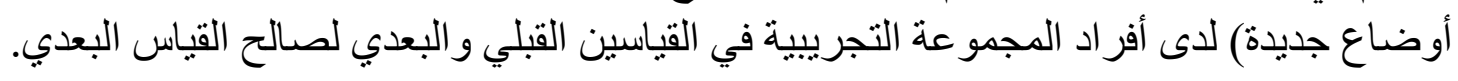

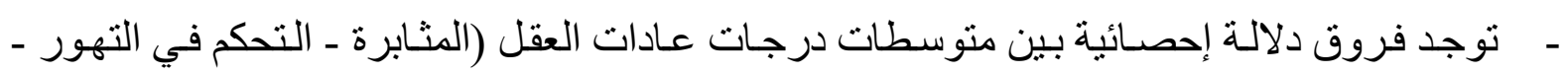

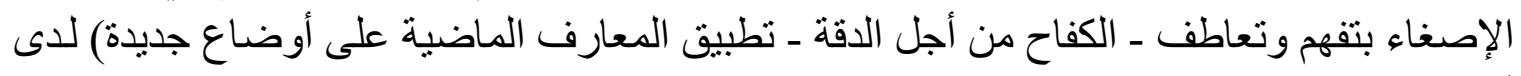

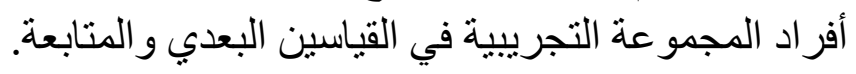

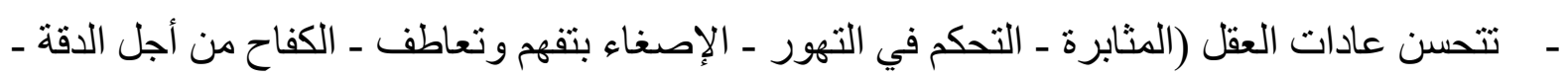

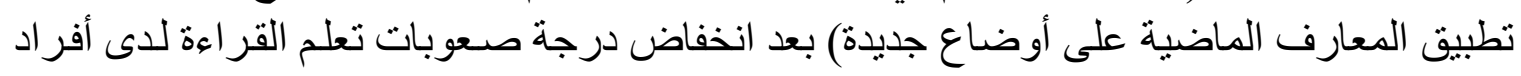

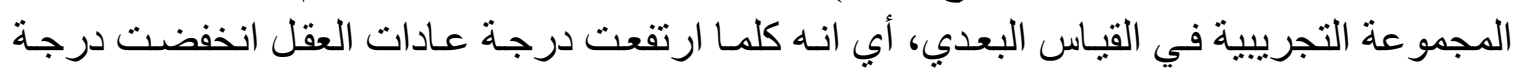
صعوبات تعلم القر اءة. ثالثا: توصيات البحث: في ضوء إجر اءات البحث الحالي، وما توصل إليه من نتائج؛ فإنه يقترح بعض التوصيات التربوية:-

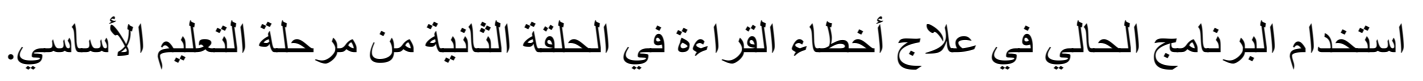
• تصحيح قر اءة التلاميذ في ضوء معايير موضو عية تكثف عن نقاط القوة ونقاط الضعف في قر اءتهم، تمهيداً 


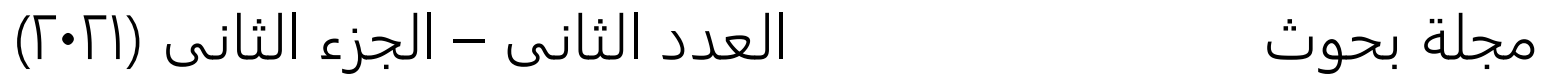 \\ "العلوم التربوية بحوبة"}

ت تشجيع معلمي اللغة العربية في مختلف المر احل الدراسية على استخدام إستر اتيجيات مـا ور راء المعرفة في تتمية مهار ات اللغة العربية بصفة عامة ومهار ات القر اءة بصفة.

تدريب تلاميذ المر احل المختلفة على استخدام إستر اتيجيات ما ور اء المعرفة لتحسين تحصيلهم الدراسي.

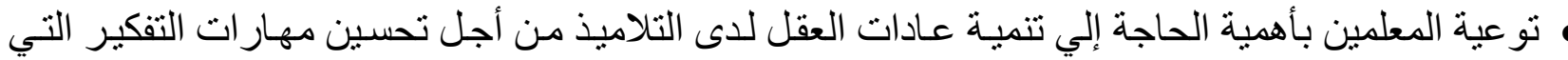

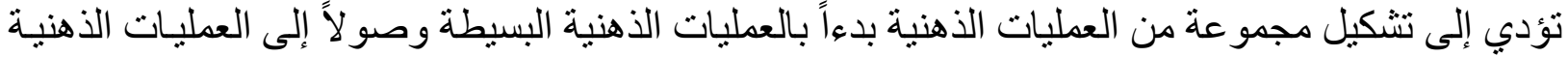

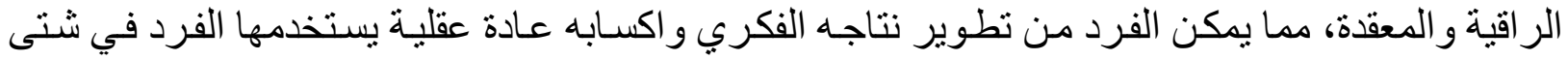

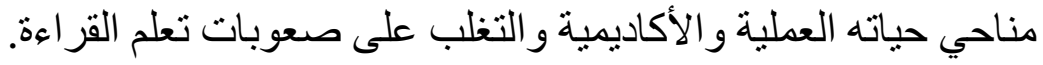

تضمين إستر اتيجيات ما ور اء المعرفة في المناهج الدر اسية بصورة كلية مـع المشاركة من قبل التبل التلاميذ في

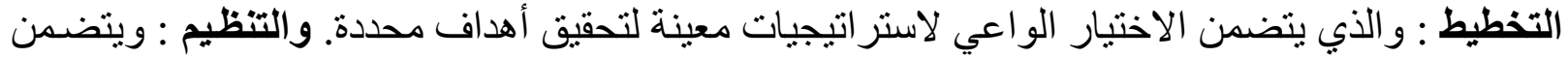

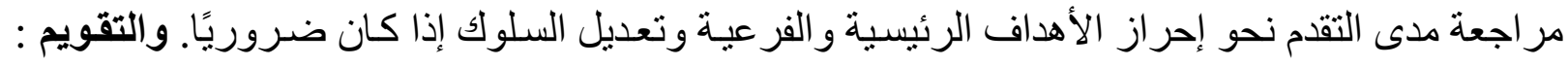
ويتضمن تقدير مدى التقدم الحالي في عمليات محددة ، ويحدث ألثاء أنثاء التعلم. تكثيف حصص الأنشطة المتخصصـة بتحسين عادات العقل كي تعم الفائدة على جميع التلاميذ ذوي صعوبات التعلم.

مبناء أداة معيارية تدرج في كتيبات يعمل بها كدليل للمعلم في التعرف علي عادات العقل لدي التلاميذ ودرجة

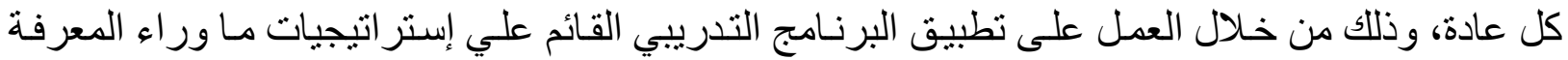

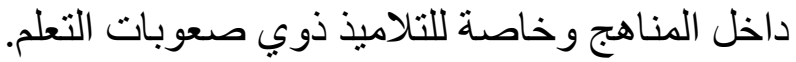

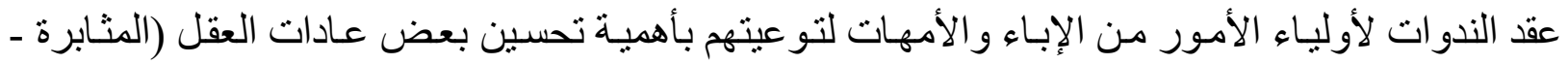

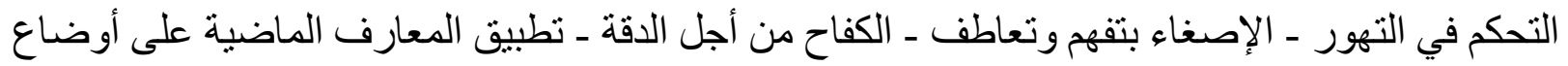
جديدة) لأبنائهم ذوي صعوبات التعلم و العاديين أيضا.

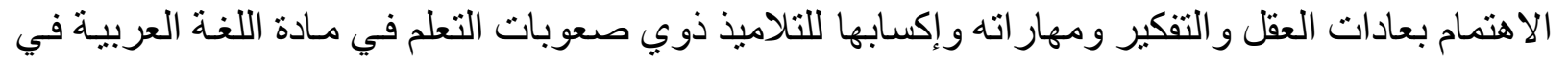
جميع المستويات التعليمية، وكذلك الأطفال العاديين ايضا لأهمية هذه العادات.

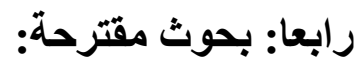
وبعد ما أسفر عنه البحث من النتائج؛ فإنه يقترح القيام بالدراسات و البحوث التالية: ت تنمية مهار ات القر اءة الجهرية باستخدام برنامج قائم على استر اتيجيات مـا ور اء المعرفة للى تلاميذ ذوي صعوبات تعلم القر اءة. ف فعالية برنامج تدريبي قائم على الأنشطة التربوية في تحسين عادات العقل لدى تلاميذ ذوي صعوبات تعلم الكتابة. 


$$
\text { "العلوم التربوية " مجلةث }
$$

فع فاليـة برنـامج تدريبي في تحسين عـادات العقل وخفض بعض الاضطر ابات السلوكية لدى تلاميذ ذوي صعوبات تعلم القر اءة.

ف فعالية برنامج تدريبي باستخدام استر اتيجيات ما ور اء المعرفة لتحسين الانتباه وفرط الحركة و الاندفاعية لدي ت تلاميذ ذوي صعوبات التعلم.

ف فعالية برنامج تدريبي باستخدام استر اتيجيات مـا ور اء المعرفة لتحسين عادات العقل لدي طلاب المرحلة الثانوية.

در اسة العلاقة بين إستر اتيجيات ما وراء المعرفة وبعض الاضطر ابات النفسية لدي تلاميذ ذوي صعوبات التعلم.

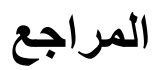

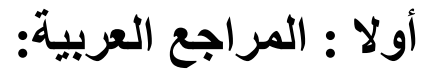

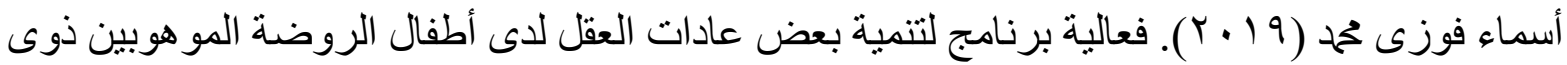

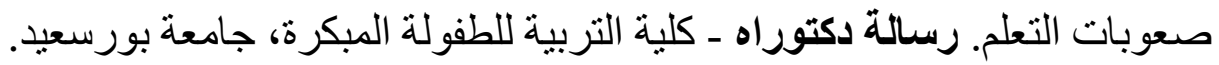

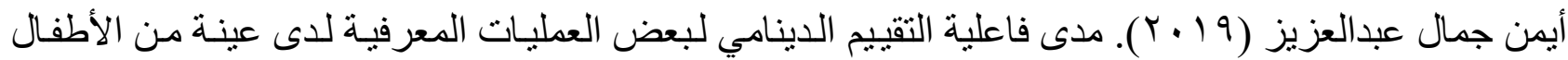

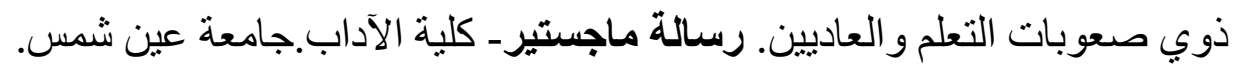

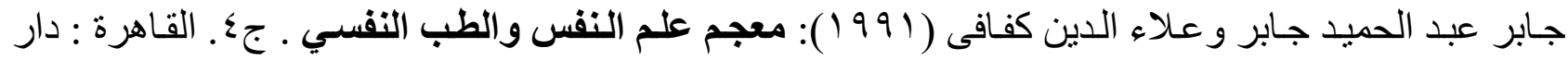
النهضة العربية. جابر عبدالحميد جابر (1991) (191): سيكولوجية التعلم ونظريات التعلم ، دار الكتاب الحديث ، الكويت .

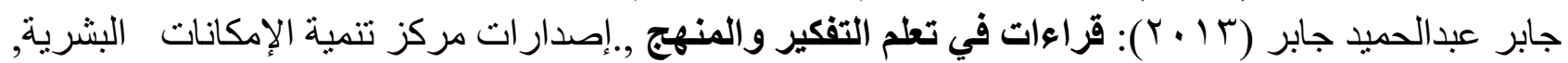

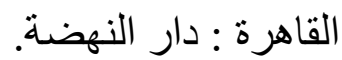

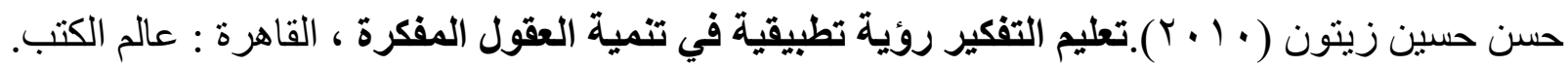

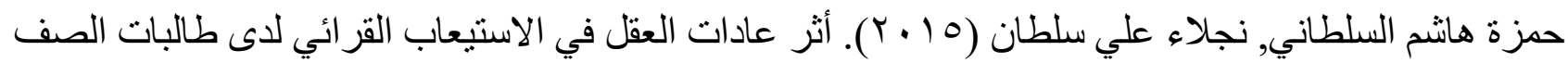

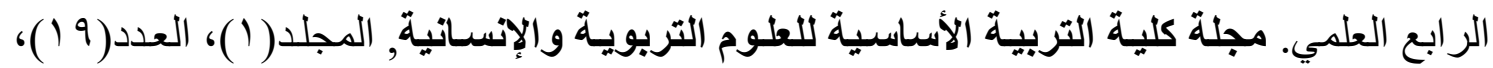
rTO-r.

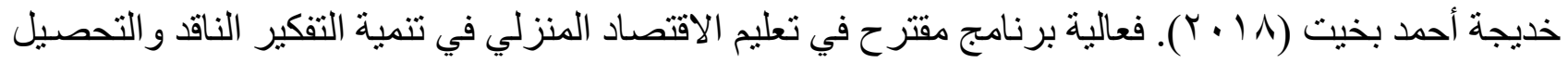

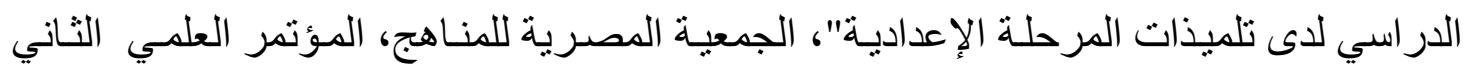

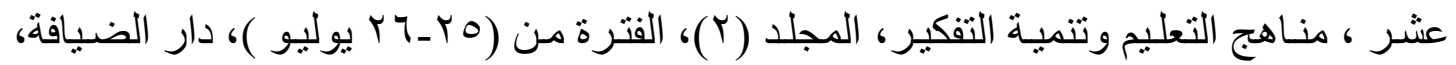
جامعة عين شمس.

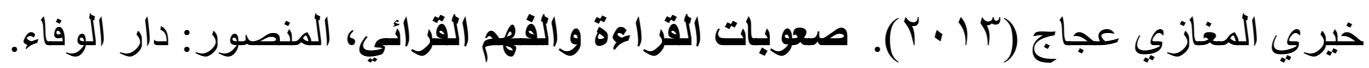




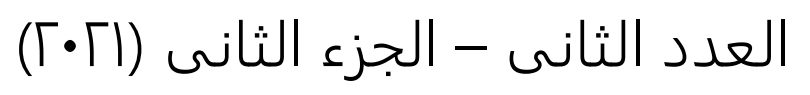

مجلة بحوث

"العلوم التربوية بحوبة"

رجاء محمود أبو علام و علاء سعيد حمحد الدرس، أماني سعيدة سيد إبر اهيم (ع ( ب ب). فعاليـة برنـامج تدريبي قائم

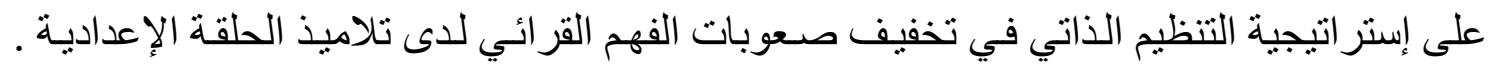

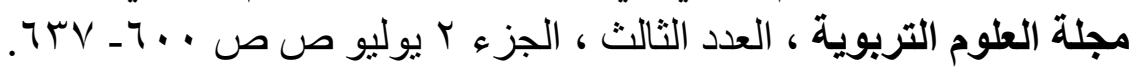

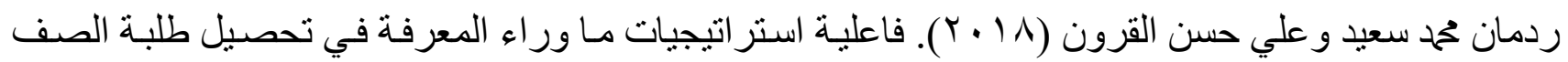

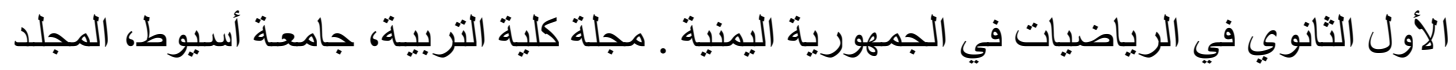

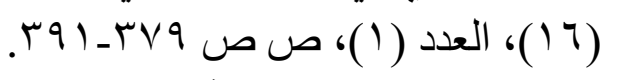

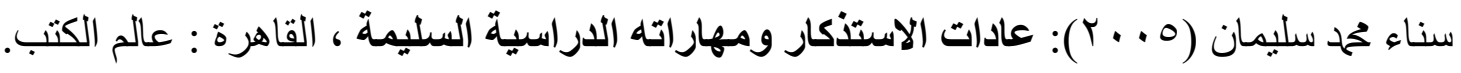

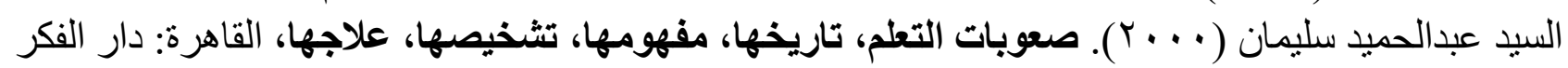

$$
\text { العربي. }
$$

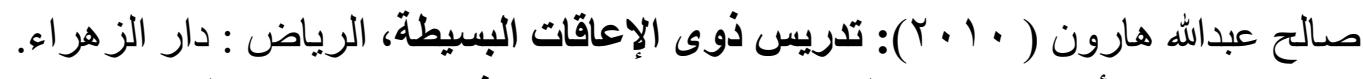

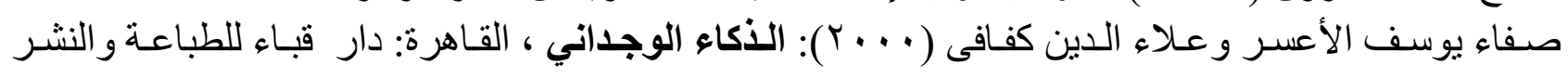

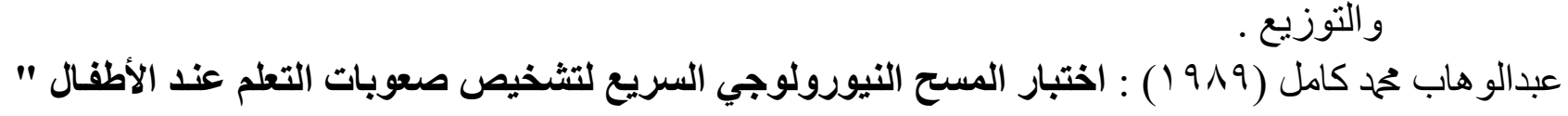

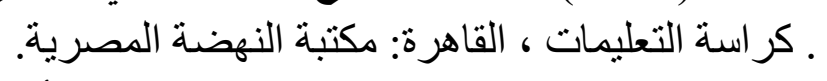

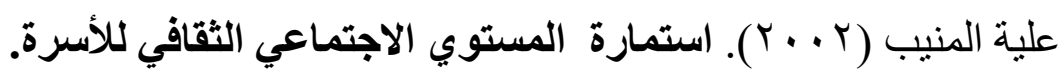

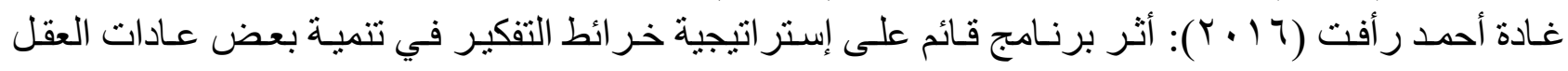

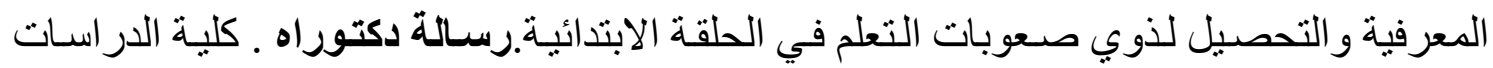

$$
\text { العليا للتربية - جامعة القاهرة. }
$$

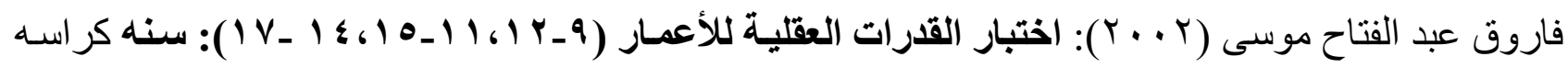

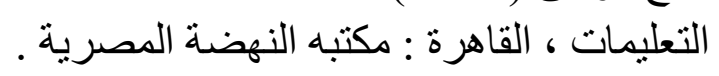

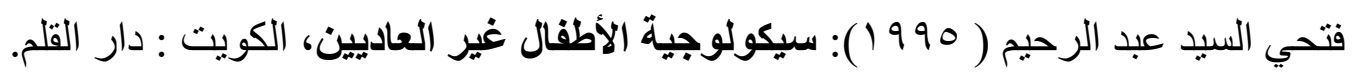

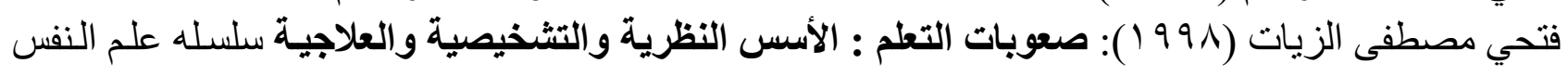

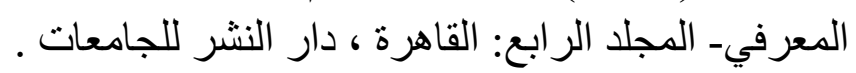

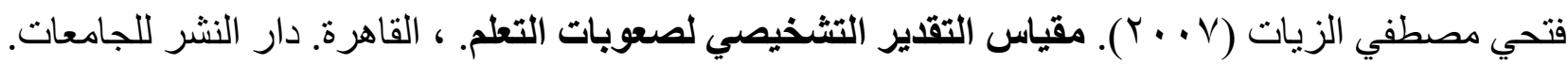

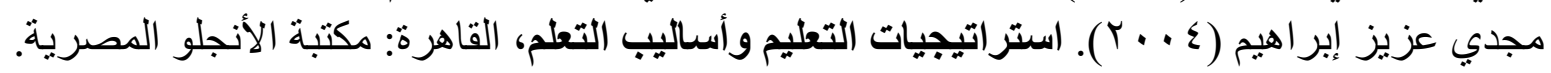

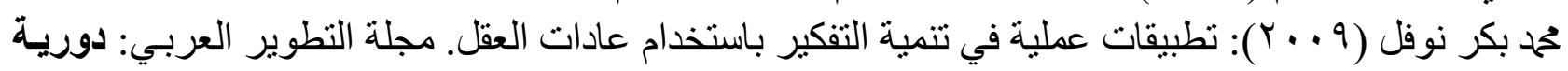

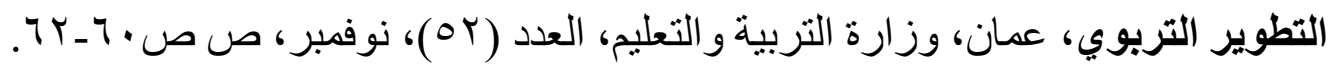

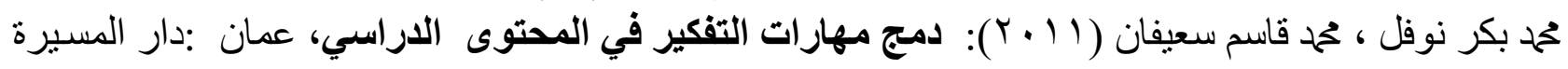
للنشر.

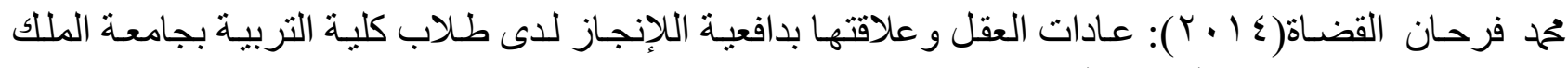

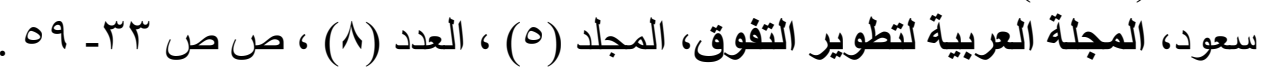




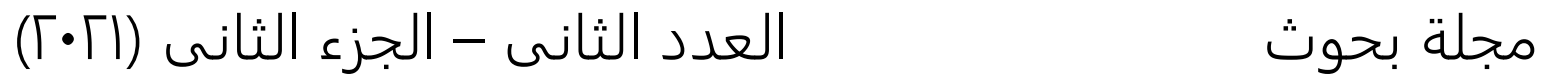 \\ "العلوم التربوية " مجوبة"}

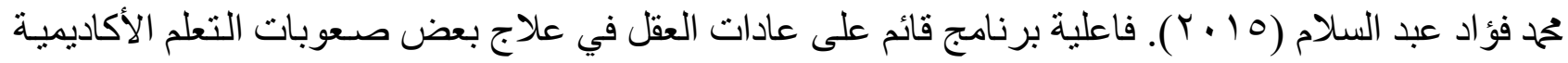

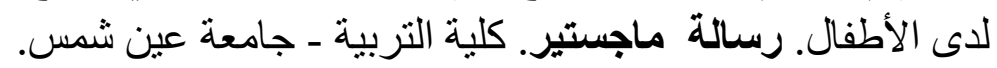

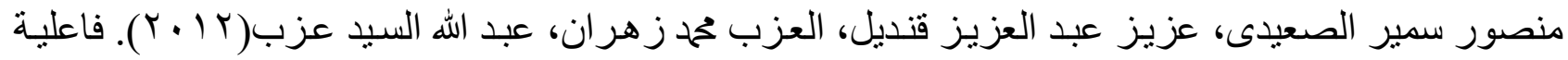

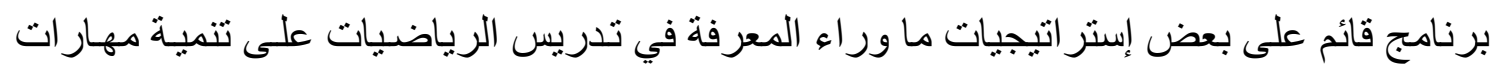

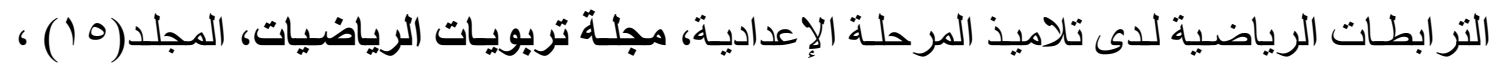

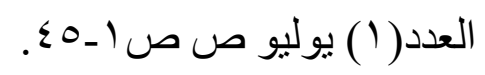

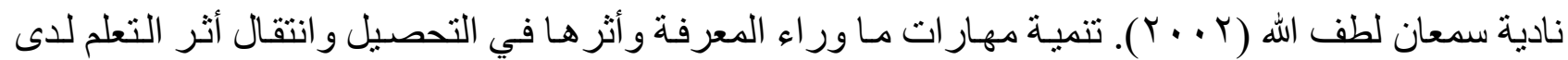

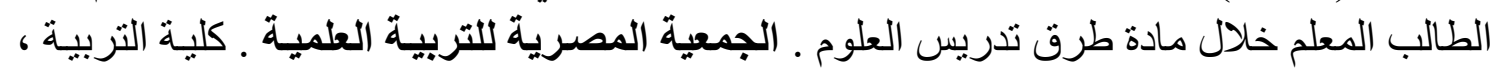

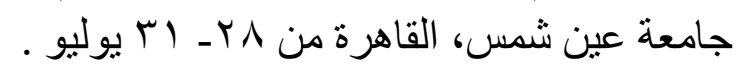

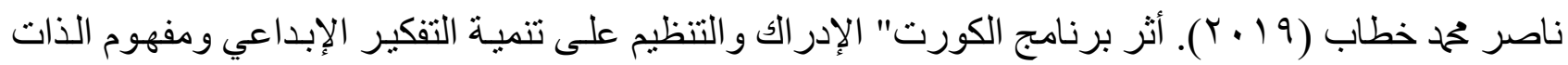

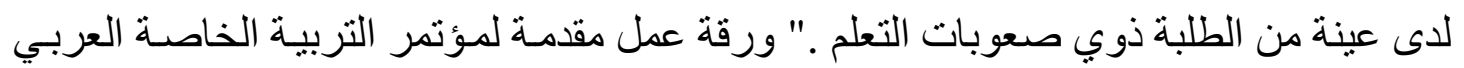

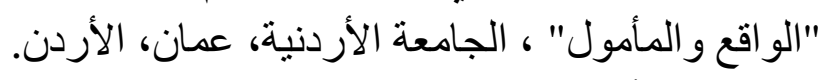

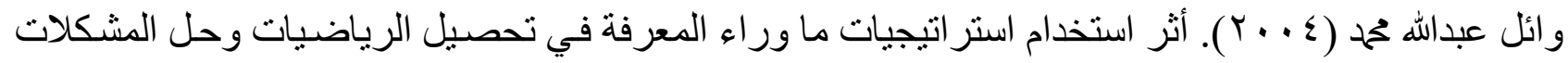

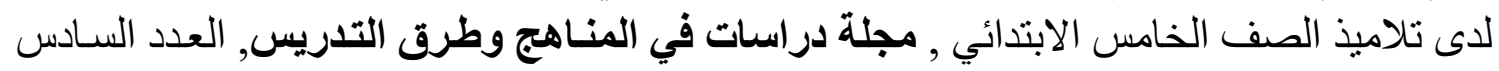

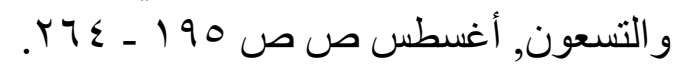

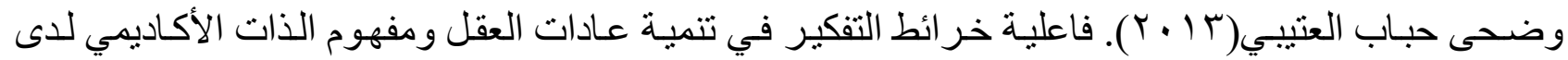

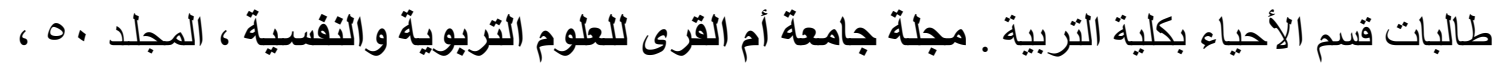

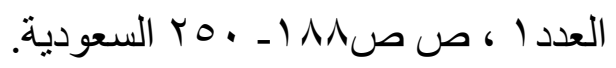

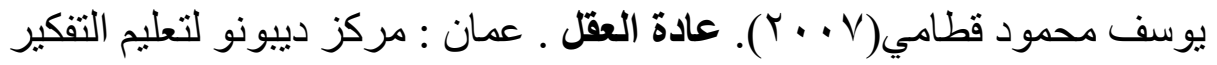
ثانيا: المراجع الأجنبية:

Andrson, L., (2018): The impact of locus of cotrol reinforcements and metaconition on mathematics achievment of undergraduate students Dissertation presented, in partial fulfillment of the requirements for the degree doctor of education in the graduate school of Texas southern University.

Benton, K., Harley, G., \& Susan, E. (2009): Met cognitive Behavior in Good and Poor Readers (Good Readers, Reading Strategies, Learning Disabilities). Diss. Abst. Inter., 53 (34-A), 136-149.

Buchel, F. P. (2019): des stratégier d'apprentissage a UN enseignement métacognitif. Education et recherche 12 année 3/90 p 297-303. 


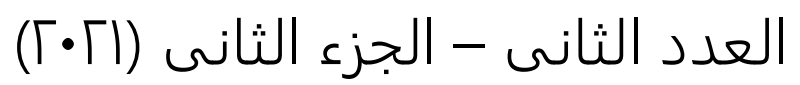

مجلة بحوث

"العلوم التربوية بهوبة"

Costa, A. \& Kallick, B. (2003). What are Habits of Mind ? Retrieved, From: http://www.Habitsofmin.net/whatare.htm.(9-3-2016).

Costa, A. \& Kallick, B. (2004). Habits of Mind . Retrieved , From: http://www. Habits-of-mind.net/whatare.html.(12-4-2016)

Costa, A.; Kallick, B. (2005) Habits of Mind a Curriculum for Community High School of Vermont Students Based on Habits of Mind: A Developmental Series.

Culler, A. (2012). From dropouts to higher achievers: Habits of mind. PhD thesis, ED. 344718, U.K.

Gama, C. (2018). Integrating Metacognition Inctruction in Interactive learning Environments, Doctor of Philosophy, University of sussex, Available at online http://homes.dcc.ufba. br/ claudiag/thesis/ThesisGama.pdf.

Kaplan \& Sadock's, (2004): "Synopsis of psychiatry behavior sciences clinical psychiatry", Jack crebb, mass publishing.

Kavale, K. (2019). Quantitative research synthesis: meta-analysis of research on meeting special educational needs. In L. Florian (Ed.), The SAGE handbook of special education. (pp. 207-221). London: Sage Publications.

Louca, Eleonora (2018): The Concept and Instruction of Metacognition, Journal of $\begin{array}{lllll}\text { Teacher Development, } & \text { Vol.7, } & \text { No.1, } & \text { PP. } & 9-30\end{array}$ (http://triangle.co.uk/pdf/viewpdf.asp?jtde

Marfa, H (2018). Development of learning and social skills in children with learning disabilities: An educational interventionprogram", Procedia - Social and Behavioral Sciences, 209. Pp.221-228. .

Montague, M. (2018). Cognitive strategy instruction in mathematics for students with learning disabilities. Journal of Learning Disabilities, 30(2), 197-213.

Perkins, D. N. (2003). Education for insight, journal of Educational Leader ship, V.(49),No.(2),pp(4-8)

Rottman. T, Cross. D. (2019). Using Informed Strategies for learning to enhance the reading and thinking skills of children with learning disabilities. Journal of Learning Disabilities, 23(5), 270-289. 


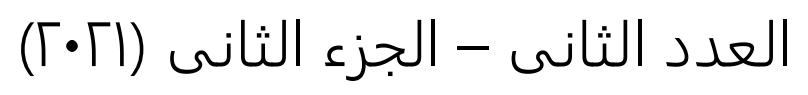

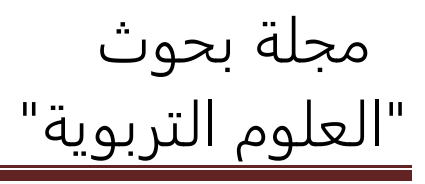

Rourke, B. P. (2020). The NLD syndrome and the white matter model. In B. P. Rourke (Ed.)Syndrome of nonverbal learning disabilities: Neurodevelopmental manifestations. New York: Guilford Press.

Short, N. (2012): Cognitive, met cognitive, motivational and affective differences among normally achieving, Learning disabled, and developmentally handicapped students: How much do they effect school achievement? Journal of clinical child psychology. 21 (3), 229-239. 


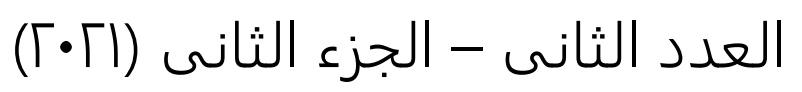

مجلة بحوث

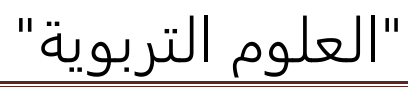

\title{
the effectiveness of a training program based on metacognitive strategies to improve the habits of mind among primary school students with learning difficulties.
}

\author{
Amr Ali Muhammad Yunus \\ PhD Researcher - Educational Psychology-Facutly of women- Ain shams \\ University \\ $\underline{\text { Supervisor }}$ \\ Prof. Dr. Sanaa Muhammad Suleiman \\ Professor of educational psychology- Facutly of women- Ain shams University \\ Dr. Shadia Abdelaziz Mohtadi \\ Teacher of educational psychology- Facutly of women- Ain shams University
}

\begin{abstract}
The study aims to reveal the effectiveness of a training program based on metacognitive strategies to improve the habits of mind among primary school students with learning difficulties. The sample consisted of (40) male and female primary school pupils with learning difficulties, and the group was divided into two groups: the experimental group and the control group. The Diagnostic Assessment Scale for Learning Difficulties to Read (Prepared / Fathi Mostafa Al-Zayat, 2007 AD). Scale of habits of mind for students with learning difficulties reading (preparation / researcher). A training program based on metacognitive strategies to improve the habits of mind for elementary school students with reading difficulties (preparation / researcher). Results indicate the following: There are statistically significant differences between the mean scores of the members of the experimental and control groups in the post-measurement on the habits of mind scale in favor of the post-measurement, There are statistically significant differences between the mean scores of the experimental group members in the pre and post measurements on the habits of mind scale in favor of the post measurement, There are no statistically significant differences between the mean scores of the experimental group members in the post and the follow up measures on the habits of mind scale.
\end{abstract}

key words : Metacognition -Habits of Mind - learning difficulties. 